\title{
Unveiling the Structure-Activity Relationships at the Orthosteric Binding Site of P2X Ion Channels: The Route to Selectivity.
}

Andreas Isaak, ${ }^{\text {a\# }}$ Clemens Dobelmann, ${ }^{\text {a\# }}$ Friederike Theresa Füsser, ${ }^{b}$ Katharina Sophie Erlitz, ${ }^{a}$ Oliver Koch ${ }^{\mathrm{b}}$ and Anna Junker. ${ }^{* a}$

\# the authors contributed equally

* corresponding author

a European Institute for Molecular Imaging (EIMI), Waldeyerstr. 15, 48149 Münster, Germany. Tel.: +49-251-8333363; Fax: +49-251-8332144; E-mail: anna.junker@wwu.de

b Institut für Pharmazeutische und Medizinische Chemie der Universität Münster, Corrensstr. 48, 48149 Münster, Germany. 


\begin{abstract}
The orthosteric ATP-binding site of the P2X receptors is poorly understood. Only a few compounds were well characterized for their P2X receptor functional activity and subtype selectivity. This study represents the first fully functional characterization of various ATP derivatives combined with in silico studies to advance the understanding of SARs at the orthosteric binding sites of P2X receptors leading to the identification of several subtype-selective $\mathrm{P} 2 \mathrm{X}$ receptor agonists and compounds with agonistic as well as antagonistic profiles.
\end{abstract}

\title{
Key words
}

P2X, P2X receptors, agonist, antagonist, selectivity, activity, functional assay, homology

\section{Introduction}

The purinergic P2X receptors belong to the family of ligand-gated non-selective cation channels. Seven different P2X subunits (P2X1-7) have been identified, which form homo- or heterotrimeric P2X receptors. ${ }^{1}$ Each subunit consists of two transmembrane domains (TM1 and TM2), a larger extracellular loop and intracellular $\mathrm{N}$ - and $\mathrm{C}$ - termini. ${ }^{2,3}$ The endogenous ligand for $\mathrm{P} 2 \mathrm{X}$ receptors is extracellular ATP (1) which addresses the inter-subunit cavity in the ectodomain that is about 280 amino acids long and whose tightening induces the opening of the ion channel within milliseconds. ${ }^{4}$ The gating behavior after activation of P2X ion channels is complex and depends on the exposure time and concentration of extracellular ATP. Within few seconds of ATP application, an opening that only allows the passage of small cations like $\mathrm{Na}^{+}, \mathrm{K}^{+}$, and $\mathrm{Ca}^{2+}$ will be formed. In contrast, a longer ATP application leads to a pore dilation that allows the permeation of larger cations like dyes such as e.g., Oxazole yellow (YO-PRO-1). ${ }^{5,6}$ The properties of P2X ion channels lead to their involvement in a wide variety of physiological and pathophysiological processes such as synaptic transmission, regulation of neurotransmitter release, contraction of smooth muscles, inflammation, and neuropathic pain. ${ }^{7-12}$ The published X-ray crystal and CryoEM structures of the P2X3, P2X4, and P2X7 receptors allow the construction and evaluation of molecular models for structure-guided drug discovery. ${ }^{13-17}$ However, in the case of orthosteric 
ligands (agonists and antagonists) apparent conserved nature of the ATP-binding site seems to pose some difficulties in achieving strong subtype-selectivity. ${ }^{18}$

\section{$\mathrm{P} 2 \mathrm{X}$ receptor agonists}<smiles>Nc1ncnc2c1ncn2[C@@H]1O[C@H](COP(=O)(O)OP(=O)(O)OP(=O)(O)O)[C@@H](O)[C@H]1O</smiles>

Adenosin-5'-triphosphate, ATP (1)<smiles>CSc1nc(N)c2ncn(C3OC(COP(=O)(O)OP(=O)(O)OP(=O)(O)O)[C@H](O)[C@H]3O)c2n1</smiles>

2-Methylthio-ATP (2)<smiles>Nc1ncnc2c1ncn2C1CCC(COP(=O)(O)P(=O)(O)OP(=O)(O)O)O1</smiles>

BzBz-ATP (3)

mixture of 2 '- and 3 '-O ester<smiles>C1CCCCC1</smiles><smiles>C=CC(=CC)C(=O)c1ccccc1</smiles><smiles>Nc1ncnc2c1ncn2[C@@H]1O[C@H](COP(=O)(O)CP(O)P(=O)(O)OP(=O)(O)O)[C@@H](O)[C@H]1O</smiles>

$\alpha, \beta-M e t h y l e n e-A T P(\mathbf{4})$

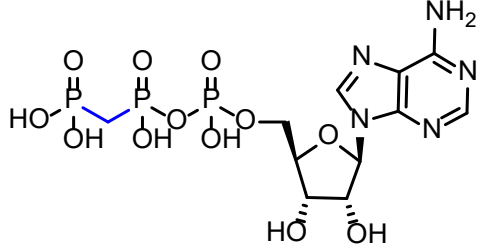

$\beta, \gamma$-Methylene-ATP (5)<smiles>Nc1ncnc2c1ncn2[C@@H]1O[C@H](COP(=O)(O)OP(=O)(O)OP(O)(O)=S)[C@@H](O)[C@H]1O</smiles>

ATP-yS (6)

\begin{tabular}{|c|c|c|c|c|c|}
\hline Cmpd. & P2X1 & P2X2 & P2X3 & P2X4 & P2X7 \\
\hline $\mathbf{1}$ & $0.06^{\#, 19}$ & $11^{\S, 20}$ & $0.34^{\#, 19}$ & $0.5^{\#, 19}$ & $96^{\#, 19}$ \\
\hline $\mathbf{2}$ & $0.06^{\#, 19}$ & $0.8^{\#, 21}$ & $0.36^{\#, 19}$ & $2.2^{\#, 19}$ & $>100^{\#, 19}$ \\
\hline $\mathbf{3}$ & $0.002^{\#, 19}$ & $0.4^{\#, 21}$ & $0.08^{\#, 19}$ & $0.5^{\#, 19}$ & $4.7^{\#, 19}$ \\
\hline $\mathbf{4}$ & $0.2^{\#, 19}$ & $>100^{\#, 21}$ & $0.7^{\#, 19}$ & $8.3^{\#, 19}$ & $>100^{\#, 19}$ \\
\hline $\mathbf{5}$ & $2^{\S, 22}$ & $>300^{\S, 22}$ & $9.2^{\S, 22}$ & $>300^{\S, 22}$ & $>300^{\S, 22}$ \\
\hline $\mathbf{6}$ & $2.3^{\#, 19}$ & $1.3^{\#, 21}$ & $0.7^{\#, 19}$ & $11^{\#, 19}$ & $>100^{\#, 19}$ \\
\hline
\end{tabular}

Table 1. Selected agonists and their $\mathrm{EC}_{50}$-values $(\mu \mathrm{M})$ at $\mathrm{P} 2 \mathrm{X}$ receptors: Adenosine triphosphate (ATP, 1), 2-methylthio-ATP (2-meS-ATP, 2), 2/3'-O-4-(Benzoylbenzoyl)-ATP (BzBzATP, 3), alpha, beta-methyleneATP ( $\alpha, \beta$-meATP, 4), beta, gamma-methylene-ATP ( $\beta, \gamma$-meATP, 5), and adenosine-5'-O-(3-thio) triphosphate (ATPYS, 6). \$Patch-Clamp Recordings (Current), ${ }^{\#} \mathrm{Ca}^{2+f l u x .}$ 
In the past, only a limited number of P2X receptor agonists, derived from modifications of the endogenous ligand ATP (1, Table 1), have been reported. ${ }^{19,21}$ Furthermore, several of those agonists were not fully characterized at all P2X receptor subtypes. A few examples of wellcharacterized P2X agonists are 2-methylthio-ATP (2-meSATP, 2), that is described as a full agonist at the $\mathrm{P} 2 \mathrm{X} 1,{ }^{19} \mathrm{P} 2 \mathrm{X} 2,{ }^{21} \mathrm{P} 2 \mathrm{X} 3,{ }^{19}$ and the $\mathrm{P} 2 \mathrm{X} 2 / 3$ heterotrimeric receptor. ${ }^{24}$ The regioisomeric mixture of 2' (3')-O-(4-benzoyl)benzoyl-ATP (BzBzATP, 3), which is often described as a selective agonist at P2X7Rs and the ATP derivatives, alpha, beta-methylene-ATP ( $\alpha, \beta-$ meATP, 4), beta, gamma-methylene-ATP ( $\beta, \gamma-m e A T P, \quad 5), \quad$ and adenosine-5'-O-(3thiotriphosphate) (ATP $\gamma S, 6)$, developed primarily to reduce the degradation rate of ATP by ectonucleotidases and therefore increase the agonists' stability, ${ }^{25}$ that show a strong preference for the P2X1R subtype, whereby $\alpha, \beta$-methylene-ATP 4 shows a preference for P2X1 and P2X3 receptors. ${ }^{26}$ In general, the understanding of structure-activity and structure-selectivity relationships at $\mathrm{P} 2 \mathrm{X}$ receptor agonists remains highly limited.

BzBzATP 3 was and sometimes still is wrongfully reported as a selective P2X7 receptor agonist in the past, but recent studies and our data (Table 3-5) demonstrate that this ATP derivate also shows an agonistic effect on other $\mathrm{P} 2 \mathrm{X}$ receptor subtypes. ${ }^{27}$ Furthermore, the photo instability of the benzophenone moiety, the decomposition of the ester bond in aqueous solution and the lack of P2X receptor subtype-selectivity makes the application of BzBzATP 3 unsuitable as a pharmacological tool. This study aims at a comprehensive evaluation of structure-activity relationships of various ATP derivatives at the P2X receptors. Hereby the structural modifications focus on the introduction of alternative ester moieties at the 2'-O and 3'-O-positions of the ribose and the various substituents at the nucleobase portion. Additionally, to the advancement of understanding the SAR relationships of agonists at P2X receptors, a photostable alternative for the widely applied BzBzATP 3 should be found. 2',3'-O-Trinitrophenyl-adenosine-5'-triphosphate (TNP-ATP, 7, Table 2) an ATP analog with blocked 2'/3'-O-positions is known as an unselective 
and orthosteric P2X receptor antagonist. ${ }^{28,29}$ In Table 2, literature reported antagonistic potency of TNP-ATP is displayed. In order to evaluate the requirement of at least one free hydroxy function for agonistic potency, several 2',3'-O-bis ester derivatives of ATP were prepared.

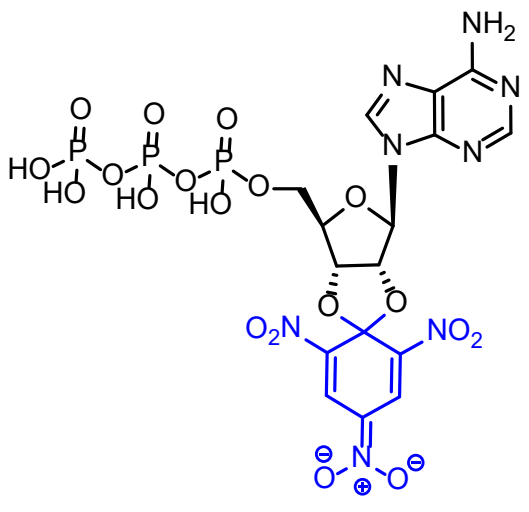

$\operatorname{TNP-ATP}\left({ }^{7}\right)$

\begin{tabular}{|c|c|c|c|c|c|c|}
\hline Cmpd & P2X1 & P2X2 & P2X3 & P2X2/3 & P2X4 & P2X7 \\
\hline TNP-ATP & $6.0^{22,29}$ & $2000^{22,29}$ & $1.0^{29}$ & $7.0^{29}$ & $15000^{29}$ & $>30000^{29}$ \\
\hline
\end{tabular}

Table 2: Orthosteric P2XR antagonist trinitrophenyl-ATP (TNP-ATP, 7) and its inhibitiory potency (IC50value $[\mathrm{nM}]$ ) in patch-clamp recordings at $\mathrm{P} 2 \mathrm{X} 1, \mathrm{P} 2 \mathrm{X} 2, \mathrm{P} 2 \mathrm{X} 3, \mathrm{P} 2 \mathrm{X} 4, \mathrm{P} 2 \mathrm{X} 7$ and heterotrimeric $\mathrm{P} 2 \mathrm{X} 2 / 3$ receptors. Patch-clamp recordings were made at HEK 293 cells stably expressing the presented rat or human $\mathrm{P} 2 \mathrm{X}$ receptor subtype.

\section{Results and discussion}

In order to determine how the variation of structural elements of ATP (1) impacts the functional P2X receptor activity, the scaffold was divided into two different areas of modifications leading to two sets of compounds (Figure 1). The first set (Tables 3, 4) focuses on 2'/3'-O-positions of the ribose moiety by introducing various aromatic monoester 10-22 or bis-ester derivatives 24-26 with reduced or enriched electron density and one bulky aliphatic 2-(adamantan-1-yl)acetyl derivative 23 lacking the aromatic ring. The esters were prepared by the reaction of ATP with carbonyl diimidazole (CDI) and the respective acid (Scheme 1). The yields of the desired monoesters 1023 were relatively low $(0.1 \%-7.8 \%)$, partially explained by the instability of the formed products, 
the formation of cyclic mono-, di- and triphosphates, the decomposition of the triphosphate group to di- and monophosphates, as well as full cleavage of the phosphate group, that were observed via LC-MS. Additionally, the formed carboxylic ester bonds were sensitive to high $\mathrm{pH}$ values. Therefore, a challenging and at least two-step purification process was performed via ion exchange and semi-preparative reversed-phase HPLC. The use of a triethylammonium acetate buffer (TEAA, pH 7) reduced the decomposition speed of the acid-sensitive triphosphate moiety. However, since the main focus of this work was the evaluation of the SARs, the synthesis route was not further optimized to obtain higher yields. The 4-nitrobenzoyl ATP ester derivative 19 could only be isolated in a $0.1 \%$ yield due to the very low reactivity of the respective benzoic acid. For all aromatic products, the 3'-O-monocarboxylic esters were formed preferentially (ratio 2:1 [3':2'esters]) while the ratio for the adamantyl derivative 23 was vice versa. Due to the rapid acyl transfer between the two vicinal alcohols, the regioisomeric mixtures of 2'- and 3'-esters were not separated and tested as mixtures. Four commercially available nucleotides with either differing stereochemistry at the 2'-O-position (30) or introduction of substituents at 2'-O-position (27-29) were applied in the SAR evaluation as well (Table 4). The second set focused on commercially available ATP derivatives with modifications at the nucleobase at 2-, 8- and $\mathrm{N}^{6}$-positions that enrich or reduce the electron density of the purine ring system.

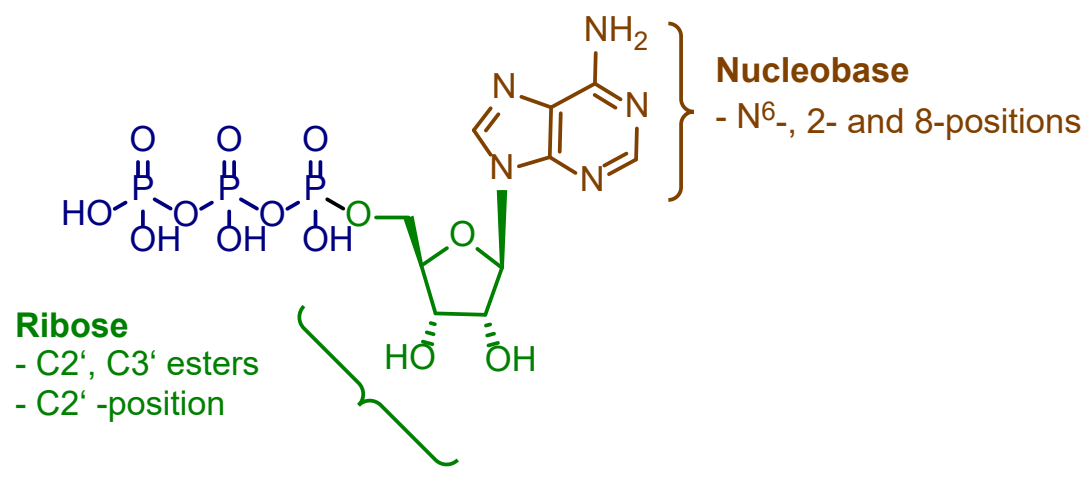

Figure 1. The two areas of scaffold modifications. 
We are highly interested in human homotrimeric $\mathrm{P} 2 \mathrm{X} 1, \mathrm{P} 2 \mathrm{X} 2, \mathrm{P} 2 \mathrm{X} 3, \mathrm{P} 2 \mathrm{X} 4, \mathrm{P} 2 \mathrm{X} 7$ and the heterotrimeric $\mathrm{P} 2 \mathrm{X} 2 / 3$ receptors and the present SAR study focuses on these targets. The prepared and commercially available nucleotides were screened in $\mathrm{Ca}^{2+}$-flux assays at P2X1, $\mathrm{P} 2 \mathrm{X} 2, \mathrm{P} 2 \mathrm{X} 2 / 3, \mathrm{P} 2 \mathrm{X} 3, \mathrm{P} 2 \mathrm{X} 4$ and $\mathrm{P} 2 \mathrm{X} 7$ receptors. Furthermore, a YO-PRO-1 dye uptake assay was performed for the $\mathrm{P} 2 \mathrm{X} 7$ receptors as it is still one of the most commonly applied read-outs of P2X7 receptor activity. The results are summarized in Tables 3-5.

\section{Structure-activity relationships of the 2'/3'-O-ester ATP derivatives}

Our analysis shows, that the BzBzATP (3) claimed as P2X7 receptor selective agonist in the literature, ${ }^{30-33}$ is potent across all tested $\mathrm{P} 2 \mathrm{X}$ receptor subtypes (see Table 3 ) with the highest activity at the heterotrimeric $\mathrm{P} 2 \mathrm{X} 2 / 3\left(\mathrm{pEC}_{50}=5.69\right)$ and homotrimeric $\mathrm{P} 2 \mathrm{X} 7$ receptors $\left(\mathrm{pE} \mathrm{C}_{50}(\mathrm{YO}\right.$ $\mathrm{PRO}-1)=6.29$ ). However, a differing P2X7 receptor activity was recorded in the $\mathrm{Ca}^{2+}$-flux assay with a $\mathrm{pEC}_{50}$-value of 3.87 (see Figure $2 \mathrm{a}$ ). All monoesters $10-23$ displayed $\mathrm{P} 2 \mathrm{X} 7$ receptor activity in the YO-PRO-1 dye uptake assay in the range of $\mathrm{pEC}_{50}$-values from 5.34 to 6.43 , while not demonstrating any or very low agonistic activity in the $\mathrm{Ca}^{2+}$-flux assay using the same cell line. A possible explanation for this observation might be the different incubation times of the agonists in the respective assay, which in the case of the $\mathrm{Ca}^{2+}{ }_{-}$flux assay are dispensed onto the cells for immediate read-out while in case of the YO-PRO-1 dye uptake assay are coincubated with the cells for $2 \mathrm{~h}$ at $37^{\circ} \mathrm{C}$ ahead of the fluorescence measurement. The lipophilic esters are not able to reach the binding pocket within the limited time frame leading to an underestimation or overestimation of their $\mathrm{P} 2 \mathrm{X} 7$ receptor activity, depending on the assay performed. The activity of the polar endogenous agonist ATP $\left(p E C_{50}\left(\mathrm{Ca}^{2+}\right.\right.$-flux $\left.)=5.88, \mathrm{pEC}_{50}(\mathrm{YO}-\mathrm{PRO}-1)=5.07\right)$ is not affected by the assay protocol. Most of the prepared monoesters display no selectivity for one particular P2X receptor subtype. The unsubstituted benzoyl ester 10 displays moderate P2X2 receptor $\left(\mathrm{pEC}_{50}\left(\mathrm{Ca}^{2+}{ }^{-}\right.\right.$flux $\left.)=4.82\right), \mathrm{P} 2 \mathrm{X} 4$ receptor $\left(\mathrm{pEC}_{50}\left(\mathrm{Ca}^{2+}\right.\right.$-flux $\left.)=5.46\right)$ and $\mathrm{P} 2 \mathrm{X} 7$ receptor $\left(\mathrm{pEC}_{50}(\mathrm{YO}-\mathrm{PRO}-1)=5.78\right)$ activity. Introduction of a 2-methyoxybenzoyl ester 11 leads to P2X4 
$\left(\mathrm{pEC}_{50}\left(\mathrm{Ca}^{2+}{ }_{\text {-flux }}\right)=5.56\right)$ and $\mathrm{P} 2 \mathrm{X} 7\left(\mathrm{pEC}_{50}(\mathrm{YO}-\mathrm{PRO}-1)=5.81\right)$ receptor selectivity, whereas the larger n-pentyl substituent adds $\mathrm{P} 2 \mathrm{X} 2 / 3$ receptor activity. Interestingly, the 3-methylbenzoic ester derivative 13 displays $\mathrm{P} 2 \mathrm{X}$ receptor activity at all but the $\mathrm{P} 2 \mathrm{X} 3$ receptor subtype. Compound 13 is equally potent in the YO-PRO-1 assay at P2X7 receptors to BzBzATP (3), with a pEC s0 $_{\text {-value of }}$ 6.00 versus 6.29 , respectively, but it shows 1 -log unit higher potency in $P 2 X 7 R \mathrm{Ca}^{2+}$-flux assay (13: $\mathrm{pEC}_{50}=4.83,3: \mathrm{pEC}_{50}=3.87$ ). Moreover we could additionally confirm the potency difference between both compounds in the P2X7 receptor triggered IL-1ß release at THP-1 cells (13: $p \mathrm{EC}_{50}$ $\left.=3.24 \pm 0.16,3: \mathrm{pEC}_{50}=2.09 \pm 0.05\right)$. The introduction of an azide moiety in compound 18 increases the activity at all except for P2X1 receptors. The 4-nitrobenzoyl ester derivative 19 was not only formed in a very low yield but also displayed rapid cleavage of the ester function in an aqueous solution; therefore, this compound could be only tested at $\mathrm{P} 2 \mathrm{X} 2\left(\mathrm{pEC} \mathrm{C}_{50}\left(\mathrm{Ca}^{2+}{ }^{2} \mathrm{flux}\right)=\right.$ 5.74) and $\mathrm{P} 2 \mathrm{X} 7(\mathrm{pEC} 50(\mathrm{YO}-\mathrm{PRO}-1)=5.34)$ receptors displaying moderate activity. The introduction of a 3-methyl group at the benzoic ester 13 leads to activity at all except the P2X3Rs. The 2-iodobenzoyl ester 14 is active at P2X2 $\left(\mathrm{pEC}_{50}\left(\mathrm{Ca}^{2+}\right.\right.$-flux $\left.)=5.62\right), \mathrm{P} 2 \mathrm{X} 2 / 3\left(\mathrm{pEC} \mathrm{C}_{50}\left(\mathrm{Ca}^{2+}\right.\right.$-flux $)$ = 6.09), $\mathrm{P} 2 \mathrm{X} 4\left(\mathrm{pEC}_{50}\left(\mathrm{Ca}^{2+}\right.\right.$-flux $\left.)=6.00\right)$ and $\mathrm{P} 2 \mathrm{X} 7\left(\mathrm{pEC}_{50}(\mathrm{YO}-\mathrm{PRO}-1)=5.76\right)$ receptors, while replacing the iodo- by a chloro- substituent in compound 15 leads to a loss of $\mathrm{P} 2 \mathrm{X} 2 / 3$ receptor activity. The 2-cloro-3-trifluoromethylbenzoyl ester 17 shows high activity among all tested P2X receptor subtypes outperforming BzBzATP (3) at all but P2X7 receptor by 0.5 to 1 -log units. Compound 17 represents a promising alternative pan P2X receptor agonist since it does not suffer from the photo liability of the benzophenone moiety while displaying similar or higher activity at the P2X receptors. The bulky naphto-1-yl 20 and 9-oxo-9H-fluoreno-2-yl 22 esters are active at $\mathrm{P} 2 \mathrm{X} 2\left(\mathrm{pEC}_{50}\left(\mathrm{Ca}^{2+}{ }_{\text {-flux }}, 20\right)=5.47 ; \mathrm{pEC}_{50}\left(\mathrm{Ca}^{2+}{ }_{\text {-flux }}, 22\right)=5.49\right), \mathrm{P} 2 \mathrm{X} 2 / 3\left(\mathrm{pEC}_{50}\left(\mathrm{Ca}^{2+}{ }^{-}\right.\right.$flux, 20 $)=$ 5.89; $\mathrm{pEC}_{50}\left(\mathrm{Ca}^{2+}\right.$-flux, 22) = 6.34), P2X4 $\left(\mathrm{pEC}_{50}\left(\mathrm{Ca}^{2+}\right.\right.$-flux, 20) $=6.21 ; \mathrm{pEC}_{50}\left(\mathrm{Ca}^{2+}{ }_{\text {-flux }}, 22\right)=$ 5.95) and $\mathrm{P} 2 \mathrm{X} 7\left(\mathrm{pEC}_{50}(\mathrm{YO}-\mathrm{PRO}-1,20)=5.47 ; \mathrm{pEC}_{50}(\mathrm{YO}-\mathrm{PRO}-1,22)=6.43\right)$ receptors, while the naphto-2-yl 21 derivative loses activity at the P2X2/3 receptor. The adamantyl ester derivative 23 shows moderate selectivity for the P2X7 receptor $\left(p E C_{50}(Y O-P R O-1)=5.79\right)$ versus $P 2 X 4$ 
receptor $\left(\mathrm{pEC}_{50}\left(\mathrm{Ca}^{2+}\right.\right.$-flux $\left.)=4.93\right)$ and is outperforming BzBzATP (3) regarding its selectivity towards other P2X receptor subtypes. The prepared bis-esters 24-26 were evaluated for their potential agonistic P2X receptor activity as well. The bisbenzoyl $\mathbf{2 4}$ ester shows selectivity for $\mathrm{P} 2 \mathrm{X} 2 / 3\left(\mathrm{pEC}_{50}\left(\mathrm{Ca}^{2+}{ }_{-}\right.\right.$flux $\left.)=5.92\right)$ and $\mathrm{P} 2 \mathrm{X} 4\left(\mathrm{pEC}_{50}\left(\mathrm{Ca}^{2+}-\mathrm{flux}\right)=5.83\right)$ receptors, while the introduction of the 4-methoxy substituent in compound 25 leads to a complete loss of agonistic potency. Interestingly the bisnaphtho-1-yl ester $\mathbf{2 6}$, while being moderately potent at P2X7R, is highly selective for the P2X7R $\left(\mathrm{pEC}_{50}\left(\mathrm{Ca}^{2+}{ }^{-}\right.\right.$flux $\left.)=4.78 ; \mathrm{pEC}_{50}(\mathrm{YO}-\mathrm{PRO}-1)=4.15\right)$. Moreover, compound 26 displays higher efficacy (superagonist) than BzBzATP (3) in the YO-PRO-1 uptake $\mathrm{P} 2 \mathrm{X} 7$ receptor assay (Figure $2 \mathrm{~b}$ ) while acting as a partial agonist in the $\mathrm{Ca}^{2+}$-flux assay. The observed agonistic activity of the bis-esters demonstrates that there is no requirement for a free hydroxy function at 2'- and 3'-positions for agonistic potency at P2X receptors.

\section{Structure-activity relationships of the ATP derivatives modified at 2'-0-position}

Next, we shifted our focus onto the 2'-O-position of the ribose moiety. Therefore, four nucleotides differing only in the substituent at the 2'-O-position were picked for the SAR study. Replacing the hydroxy group in ATP by a fluorine atom in compound 27 leads to P2X2 (pEC $50\left(\mathrm{Ca}^{2+}\right.$-flux $\left.)=5.25\right)$, $\mathrm{P} 2 \mathrm{X} 2 / 3\left(\mathrm{pEC}_{50}\left(\mathrm{Ca}^{2+}\right.\right.$-flux $\left.)=5.27\right), \mathrm{P} 2 \mathrm{X} 3\left(\mathrm{pEC}_{50}\left(\mathrm{Ca}^{2+}\right.\right.$-flux $\left.)=4.98\right)$ and $\mathrm{P} 2 \mathrm{X} 7$ receptor activities while replacing it with an amino function as in compound $\mathbf{2 8}$ shifts the activity profile towards P2X1 $\left(\mathrm{pEC}_{50}\left(\mathrm{Ca}^{2+}{ }_{-}\right.\right.$flux $\left.)=5.19\right), \mathrm{P} 2 \mathrm{X} 3\left(\mathrm{pEC}_{50}\left(\mathrm{Ca}^{2+}{ }_{-}\right.\right.$flux $\left.)=5.37\right)$ and $\mathrm{P} 2 \mathrm{X} 2 / 3\left(\mathrm{pEC}_{50}\left(\mathrm{Ca}^{2+}{ }_{-}\right.\right.$flux $\left.)=6.44\right)$ receptors. Introducing a C2'-methoxy group 29 leads to a complete loss of P2X receptor activity. Remarkably the inversion of the stereocenter at 2'-position as in compound $\mathbf{3 0}$ leads to moderate $\mathrm{P} 2 \mathrm{X} 4\left(\mathrm{pEC}_{50}\left(\mathrm{Ca}^{2+}\right.\right.$-flux $\left.)=4.98\right)$ receptor activity and selectivity over all other investigated $\mathrm{P} 2 \mathrm{X}$ receptor subtypes. 
Scheme 1. Synthesis of ATP mono and bis ester derivatives 10-26.

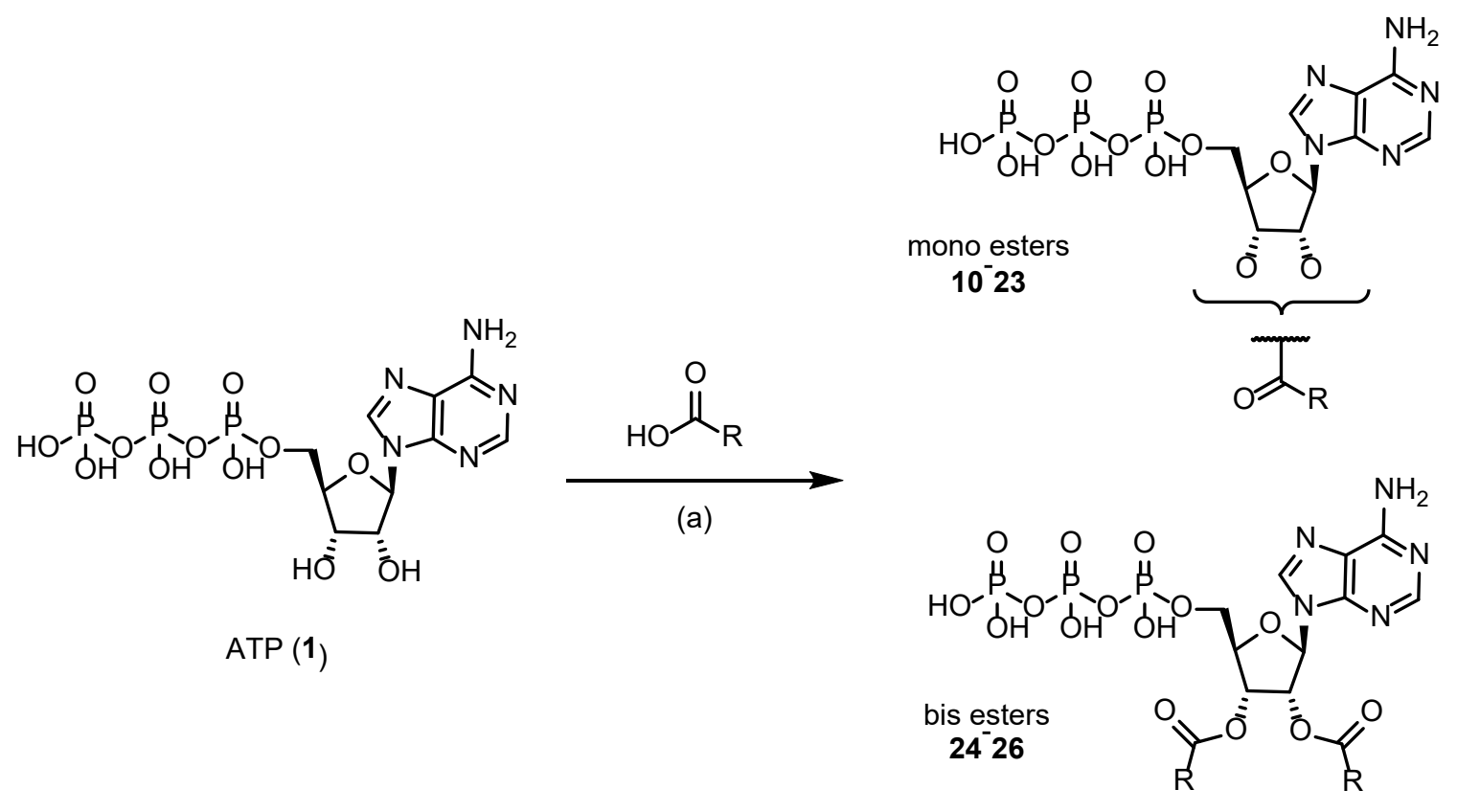

Reagents and conditions: (a) R-COOH, CDI, DMF/water, room temperature, 1-7 days.

\section{Structure-activity relationships of the nucleobase modified ATP derivatives}

Several nucleotides with varying nucleobases were tested for their $\mathrm{P} 2 \mathrm{X}$ receptor activities in the past. ${ }^{19,34}$ We are focusing on modifications at the 2-, $\mathrm{N}^{6}-$, and 8-positions (Table 5). The methylthio ATP derivate 2 modified at the 2-position of the nucleobase moiety was chosen as a reference compound. In accordance to the literature reported data (Table 1), 2-MeS-ATP (2) is potent at the $\mathrm{P} 2 \mathrm{X} 2$ receptor $\left(\mathrm{pEC}_{50}\left(\mathrm{Ca}^{2+}-\right.\right.$ flux $\left.)=6.36\right)$. However, we could not confirm the potency at P2X1 and $\mathrm{P} 2 \mathrm{X} 3$ receptors while observing activity at the $\mathrm{P} 2 \mathrm{X} 4\left(\mathrm{pEC}_{50}\left(\mathrm{Ca}^{2+}-\mathrm{flux}\right)=6.11\right)$ and also a moderate activity at the $\mathrm{P} 2 \mathrm{X} 7\left(\mathrm{pEC}_{50}(\mathrm{YO}-\mathrm{PRO}-1)=5.66\right)$ receptors. Compound 2 is outperforming BzBzATP (3) regarding its selectivity profile at other P2X receptor subtypes. Replacing the primary amine at the 6-position of the nucleobase in ATP by a chlorine $\mathbf{3 1}$ leads to an activity shift towards $\mathrm{P} 2 \mathrm{X} 1\left(\mathrm{pEC}_{50}\left(\mathrm{Ca}^{2+}\right.\right.$-flux $\left.)=6.45\right), \mathrm{P} 2 \mathrm{X} 2\left(\mathrm{pEC} \mathrm{C}_{50}\left(\mathrm{Ca}^{2+}\right.\right.$-flux $\left.)=7.06\right), \mathrm{P} 2 \mathrm{X} 3$ $\left(p E C_{50}\left(\mathrm{Ca}^{2+}{ }_{\text {-flux }}\right)=6.13\right)$, and $\mathrm{P} 2 \mathrm{X} 2 / 3\left(\mathrm{pEC}_{50}\left(\mathrm{Ca}^{2+}{ }^{-}\right.\right.$flux $\left.)=6.89\right)$ receptors whereas the replacement by a mercapto group 32 leads to a loss of function at the P2X2 receptor. Although 
both substituents in compounds $\mathbf{3 1}$ and $\mathbf{3 2}$ are approximate of the same size, they clearly induce a difference in their $\mathrm{P} 2 \mathrm{X}$ receptor selectivity. The introduction of a methyl 33 and a butyl substituent 34 at the $\mathrm{N}^{6}$ - position leads to selectivity at the P2X3 $\left(\mathrm{pEC}_{50}\left(\mathrm{Ca}^{2+}{ }_{-}\right.\right.$flux, 33$)=5.89 ; \mathrm{pEC}_{50}\left(\mathrm{Ca}^{2+}{ }_{-}\right.$ flux, 34 $)=4.52)$ and $\mathrm{P} 2 X 2 / 3\left(\mathrm{pEC}_{50}\left(\mathrm{Ca}^{2+}{ }_{-}\right.\right.$flux, 33 $)=6.58 ; \mathrm{pEC}_{50}\left(\mathrm{Ca}^{2+}\right.$-flux, 34) = 6.16) receptors. Even bulkier substituents like a phenyl moiety in compound 35 increase the functional activity at all $\mathrm{P} 2 \mathrm{X}$ receptor subtypes except for the $\mathrm{P} 2 \mathrm{X} 1$ and $\mathrm{P} 2 \mathrm{X} 7$ receptors. Compound 36 bearing a benzyl substituent leads to a shift in P2X2 $\left(\mathrm{pEC}_{50}\left(\mathrm{Ca}^{2+}-\right.\right.$ flux $\left.)=5.40\right)$ and P2X2/3 $\left(\mathrm{pEC}_{50}\left(\mathrm{Ca}^{2+}{ }_{-}\right.\right.$ flux $=5.57)$ receptor activity. Compound $\mathbf{3 7}$ is the only derivative with an extended aromatic ring system that leads to an increased $\mathrm{P} 2 \mathrm{X} 2\left(\mathrm{pEC}_{50}\left(\mathrm{Ca}^{2+}-\right.\right.$ flux $\left.)=6.38\right), \mathrm{P} 2 \mathrm{X} 3\left(\mathrm{pEC}_{50}\left(\mathrm{Ca}^{2+}-\right.\right.$ flux $)=$ $6.00)$, and $\mathrm{P} 2 \mathrm{X} 2 / 3\left(\mathrm{pEC}_{50}\left(\mathrm{Ca}^{2+}-\right.\right.$ flux $\left.)=6.55\right)$ receptor activity. Modifications at the 8-position of the nucleobase were also examined. Introduction of an azide $\mathbf{3 8}$ substituent or an additional carbonyl group as in compound $\mathbf{3 9}$ leads to a complete loss of agonistic potency at all investigated $\mathrm{P} 2 \mathrm{X}$ receptor subtypes or activity at the $\mathrm{P} 2 \mathrm{X} 3$ receptor in a micromolar range $\left(\mathrm{pEC} \mathrm{C}_{50}\left(\mathrm{Ca}^{2+}{ }_{\text {-flux }}\right)=\right.$ 4.96), respectively. Most compounds displayed in Table 5 are inactive at the $P 2 X 7$ receptor in both assays, except for compound 2. Demonstrating the P2X7 receptor's limited acceptance for nucleobase modifications. In summary, the modified nucleobase compounds in table 5 display no selectivity for one single $\mathrm{P} 2 \mathrm{X}$ receptor subtype but the compounds $2,33,34$, and 36 represent an agonistic profile at least at two particular receptors. Also, compounds $\mathbf{2}$ and $\mathbf{3 3}$ are outperforming BzBzATP 3 regarding their selectivity and potency at the P2X receptor subtypes and are presenting a promising alternatives for BzBzATP when investigating the particular P2X receptor subtypes. 
a)

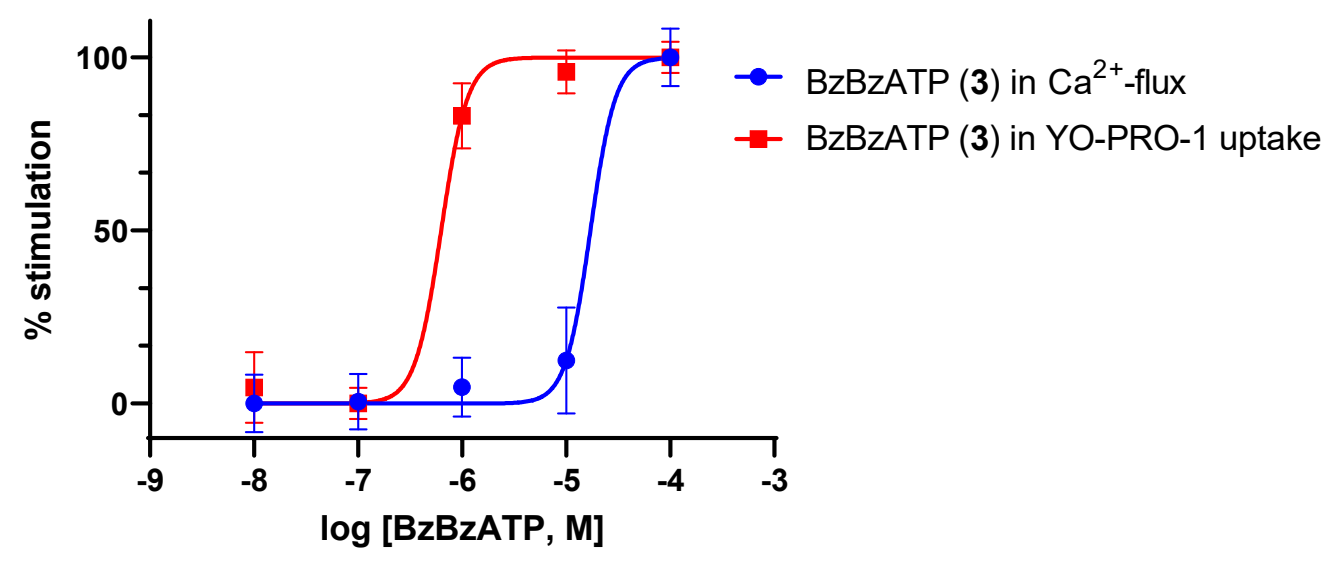

b)

P2X7R YOPRO-1 uptake

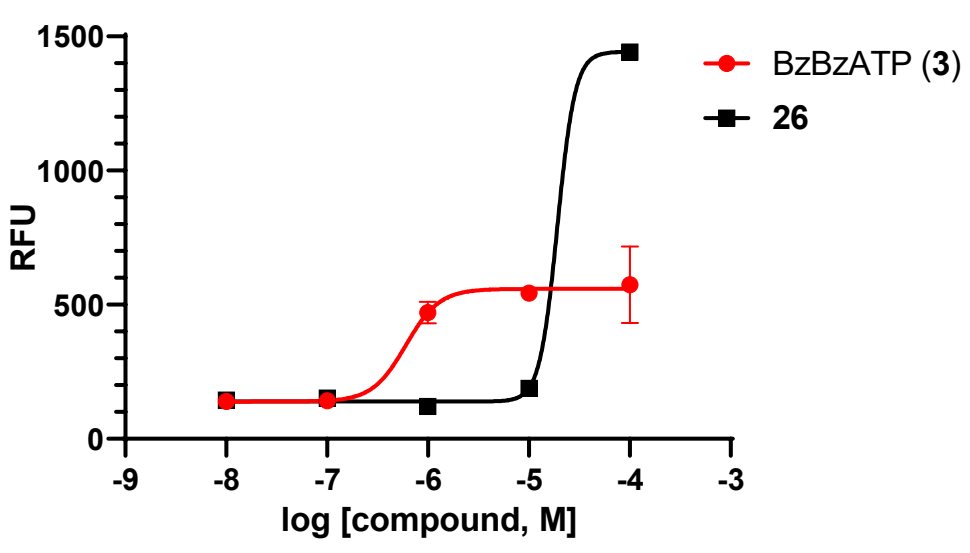

c)

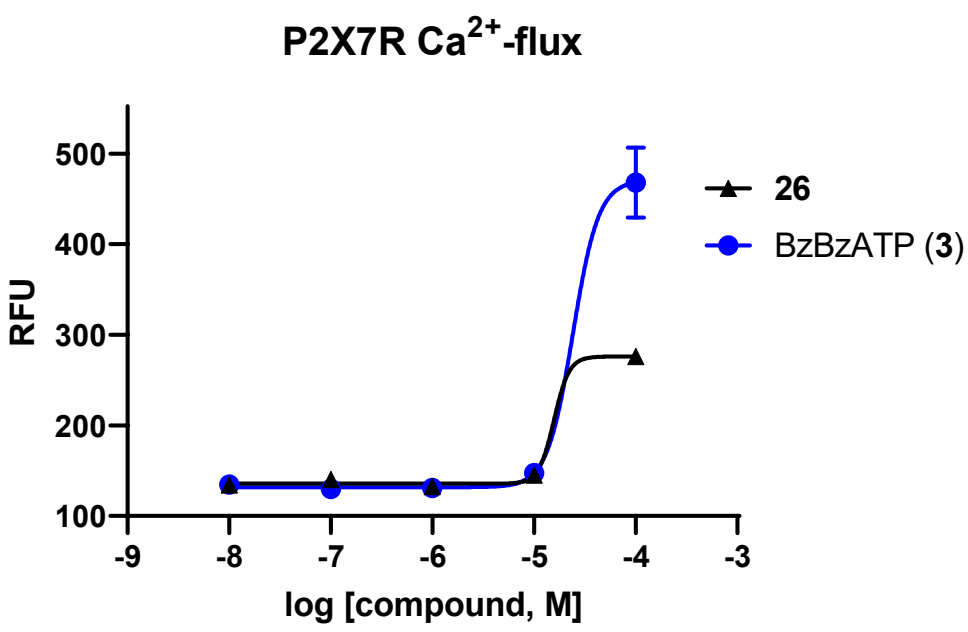

Figure 2: a) Concentration-response curves for BzBzATP (3) in the $\mathrm{Ca}^{2+}$-flux assay (blue curve) and the YO-PRO-1 dye uptake assay (red curve). b). Concentration-response curves of BzBzATP (3) and bisnapho1-yl ester 26 in the P2X7R YO-PRO-1 assay. c). Concentration-response curves of BzBzATP (3) and bisnapho-1-yl ester 26 in the P2X7R Ca ${ }^{2+}$-flux assay. RFU: relative fluorescence units. 
Table 3. The activity of ATP esters 10-26. Data presented as $p E C_{50}$ values \pm SEM $(n \geq 3)$. n.d. $=$ not determined.

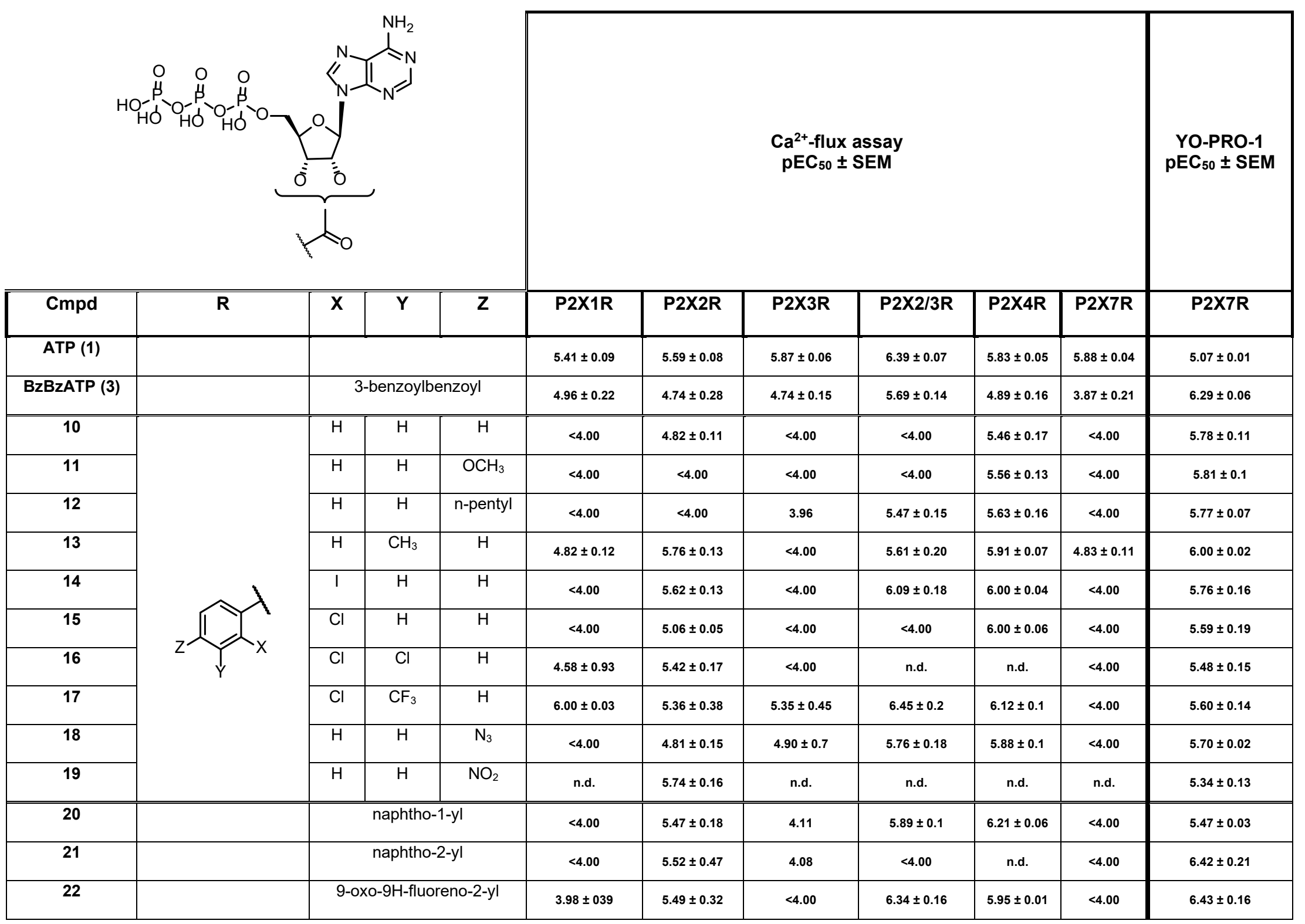




\begin{tabular}{|c|c|c|c|c|c|c|c|c|c|c|c|}
\hline 23 & & \multicolumn{3}{|c|}{ 2-(adamantan-1-yl)acetyl } & $<4.00$ & 4.05 & $<4.00$ & $<4.00$ & $4.93 \pm 0.09$ & n.d. & $5.79 \pm 0.11$ \\
\hline 24 & bis ester & $\mathrm{H}$ & $\mathrm{H}$ & $\mathrm{H}$ & $<4.00$ & $<4.00$ & $<4,00$ & $5.92 \pm 0.04$ & $5.83 \pm 0.09$ & $<4.00$ & $<4.00$ \\
\hline 25 & bis ester & $\mathrm{H}$ & $\mathrm{H}$ & $\mathrm{OCH}_{3}$ & $<4.00$ & $<4.00$ & $<4,00$ & $<4.00$ & $<4.00$ & $<4.00$ & $<4.00$ \\
\hline 26 & bis ester & \multicolumn{3}{|c|}{ bisnaphtho-1-yl } & $<4.00$ & $<4.00$ & $<4,00$ & $<4.00$ & $<4.00$ & $4.78 \pm 0.05$ & $4.15 \pm 0.36$ \\
\hline
\end{tabular}

Table 4. The activity of ATP analogs modified at the ribose moiety. Data presented as $p E C_{50}$ values \pm SEM ( $n \geq 3$ ).

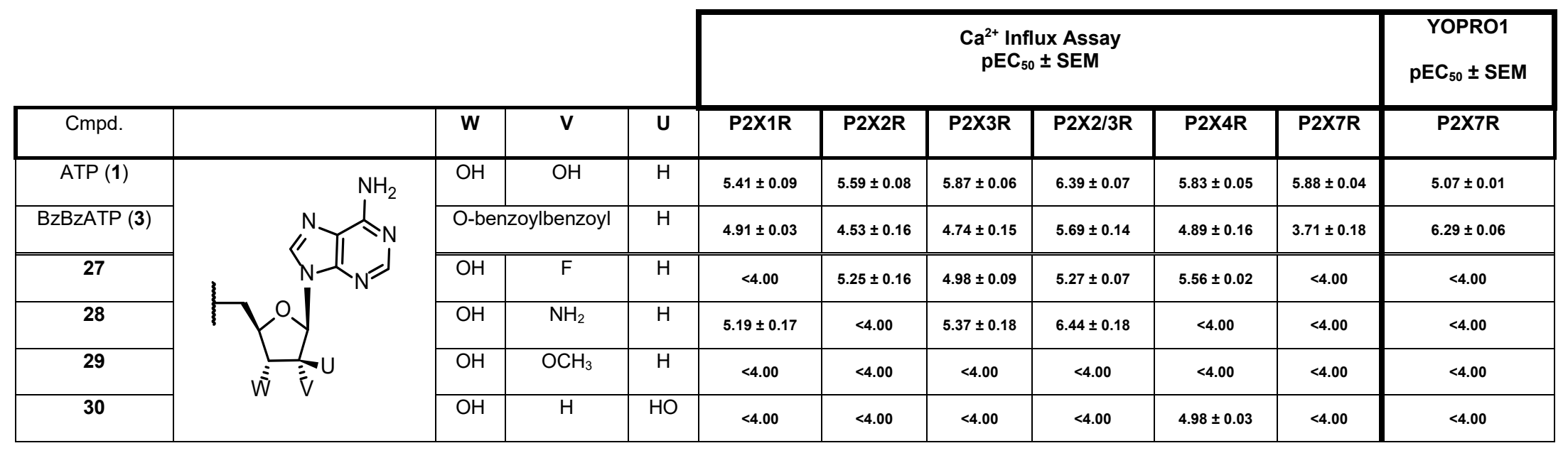


Table 3: Activity of analogs modified at the nucleobase moiety. Data presented as $p E C_{50}$ values $\pm S E M(n \geq 3)$.

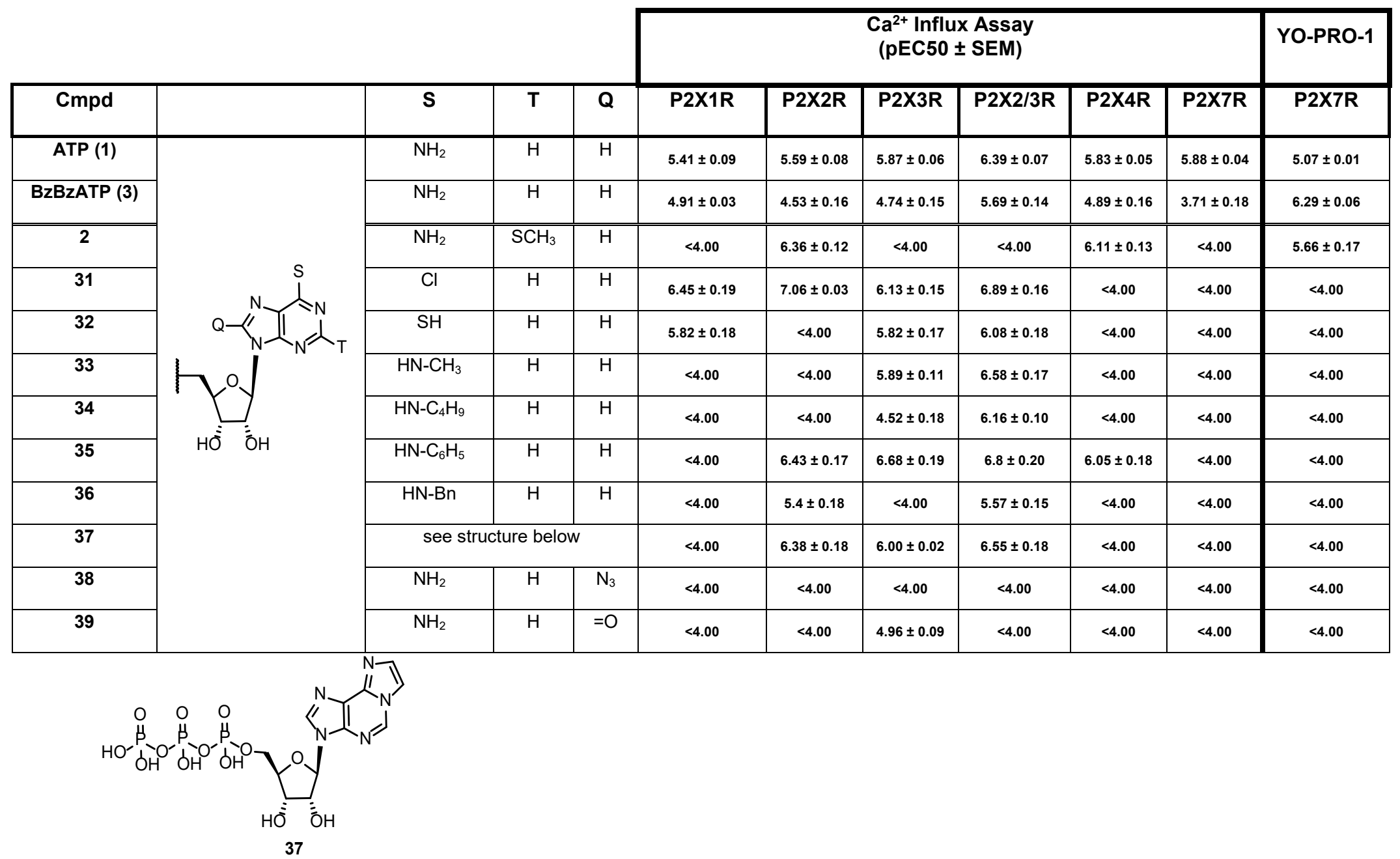




\section{ATP bis-esters as orthosteric $\mathrm{P} 2 \mathrm{X}$ receptor antagonists}

Trinitrophenyl adenosine triphosphate (TNP-ATP, 7) with the large substituent blocking the C2' and the $\mathrm{C}^{\prime}$ alcohols is a potent orthosteric inhibitor at $\mathrm{P} 2 \mathrm{X}$ receptors (Table 2), indicating the requirement of blockade of the hydroxy function for antagonistic potency. Based on this hypothesis, we selected bis esters 24-26 from our compound library to be tested in the $\mathrm{Ca}^{2+}$-flux assay for their orthosteric antagonism at P2X receptors.

Table 6: Antagonistic activity of bis ester compounds 24-26 at different P2X receptor subtypes. Data presented as $\mathrm{pIC}_{50}$ values $\pm \operatorname{SEM}(\mathrm{n} \geq 3)$.

\begin{tabular}{|c|c|c|c|c|c|c|}
\hline & P2X1 & P2X2 & P2X3 & P2X2/3 & P2X4 & P2X7 \\
\hline 24 & $<4$ & $4.58 \pm 0.17$ & $<4$ & $<4$ & $<4$ & $<4$ \\
\hline 25 & $<4$ & $<4$ & $<4$ & $<4$ & $<4$ & $<4$ \\
\hline 26 & $4.80 \pm 0.07$ & $5.00 \pm 0.14$ & $4.73 \pm 0.08$ & $4.94 \pm 0.06$ & $5.20 \pm 0.09$ & $<4$ \\
\hline
\end{tabular}

The bis-benzoyl ester 24 displays an antagonistic potency at the $\mathrm{P} 2 \mathrm{X} 2$ receptor $\left(\mathrm{plC} \mathrm{C}_{50}(\mathrm{P} 2 \mathrm{X} 2\right.$ receptor $)=4.58$ ) in low micromolar range. Interestingly this compound shows agonistic activity at $\mathrm{P} 2 \mathrm{X} 2 / 3\left(\mathrm{pEC}_{50}\left(\mathrm{Ca}^{2+}-\mathrm{flux}\right)=5.92\right)$ and P2X4 $\left(\mathrm{pEC}_{50}\left(\mathrm{Ca}^{2+}-\right.\right.$ flux $\left.)=5.83\right)$ receptors. The 4-methoxy benzoic bis ester 25 is inactive at all P2X receptor subtypes in agonistic as well as antagonistic mode. The bisnaphtho-1-yl ester 26 shows an antagonistic potency at all, except P2X7 receptor subtype. The highest antagonistic activity for compound $\mathbf{2 6}$ is measured at the P2X4 receptor $\left(\mathrm{plC}_{50}(\mathrm{P} 2 \mathrm{X} 4\right.$ receptor $\left.)=5.20\right)$, whereas the lowest inhibition potency is found at the $\mathrm{P} 2 \mathrm{X} 3$ receptor $\left(\mathrm{plC}_{50}(\mathrm{P} 2 \mathrm{X} 3\right.$ receptor $\left.)=4.73\right)$. Intriguingly compound 26 is a superagonist with moderate $\mathrm{P} 2 \mathrm{X} 7$ receptor activity (Figure 2b) in the YO-PRO-1 uptake but partial agonist in the $\mathrm{Ca}^{2+}$-flux (Figure 2c) P2X7 receptor assays. 


\section{In silico study}

The activities of the bis ester compounds 24-26 were quite surprising, so we started a computational analysis that could explain these different activities. As shown previously by Kasuya et al. and Mansoor et al. a structural change of the P2X receptor is crucial for the opening of the ion channel, which is induced by ATP binding. The ATP binding pocket is built up by two monomers and defined as head, left flipper and dorsal fin surrounding the ATP (see Figure 3a). ${ }^{13,16,35,36}$ A comparison of the human ATP-bound open (pdb 5svk) and the closed (5svj) structures of the P2X3 receptor reveals conformational changes of the left flipper regions and especially the dorsal fin (Figure 3). In the ATP bound structure, the dorsal fin exhibits a short helical structure (Figure 3b), whereas in the closed state, it exhibits an irregular loop region (Figure 3c). This indicates that this dorsal fin region is important for the conformational changes to open the ion channel.

As a starting point, the amino acid sequences of the analyzed proteins were aligned using clustal omega (see Figure 4). The residues at interaction sites 1-4 of the analyzed P2X receptors are highly conserved and show mainly interactions with the triphosphate and the adenine of the ATP. In contrast, the head, dorsal fin and left flipper domain are highly diverse in all receptors. Due to the orientation of ATP in the binding site, it can be expected that a 2'-O extension will interact with the head and an extension of the 3'-O-position with both other binding regions. Most interestingly, and with respect to the unexpected agonistic effect of compound $26, \mathrm{P} 2 \mathrm{X} 7$ subunit shows a deletion of 4 amino acids in the dorsal fin region. This could lead to a better acceptance of bulkier groups at the 3'-position compared to the other receptors. This is supported by the active P2X7 receptor structure (Figure 5) where the dorsal fin loop loses its helical structure shown in figure 3 b leading to higher flexibility of this interaction region.

Subsequently, the potential binding modes were analyzed using homology modeling and energy minimization studies. Due to the necessary movement of the interaction domains for the binding 
of the analyzed modulators, a molecular docking study was not possible in this case (data not shown). Missing structures of the human receptors for P2X4, P2X7, P2X2 and the heterotrimer P2X2/3 were complemented using homology models (see methods and materials for details). These homology models were used to analyze the possible binding of compounds 24-26. The corresponding ATP-bound structures or homology models were used to model compounds 24-26 in the binding site by modifying the ATP using MOE. Subsequently, these structures were energy minimized using MOE and the needed structural arrangements were analyzed in detail.
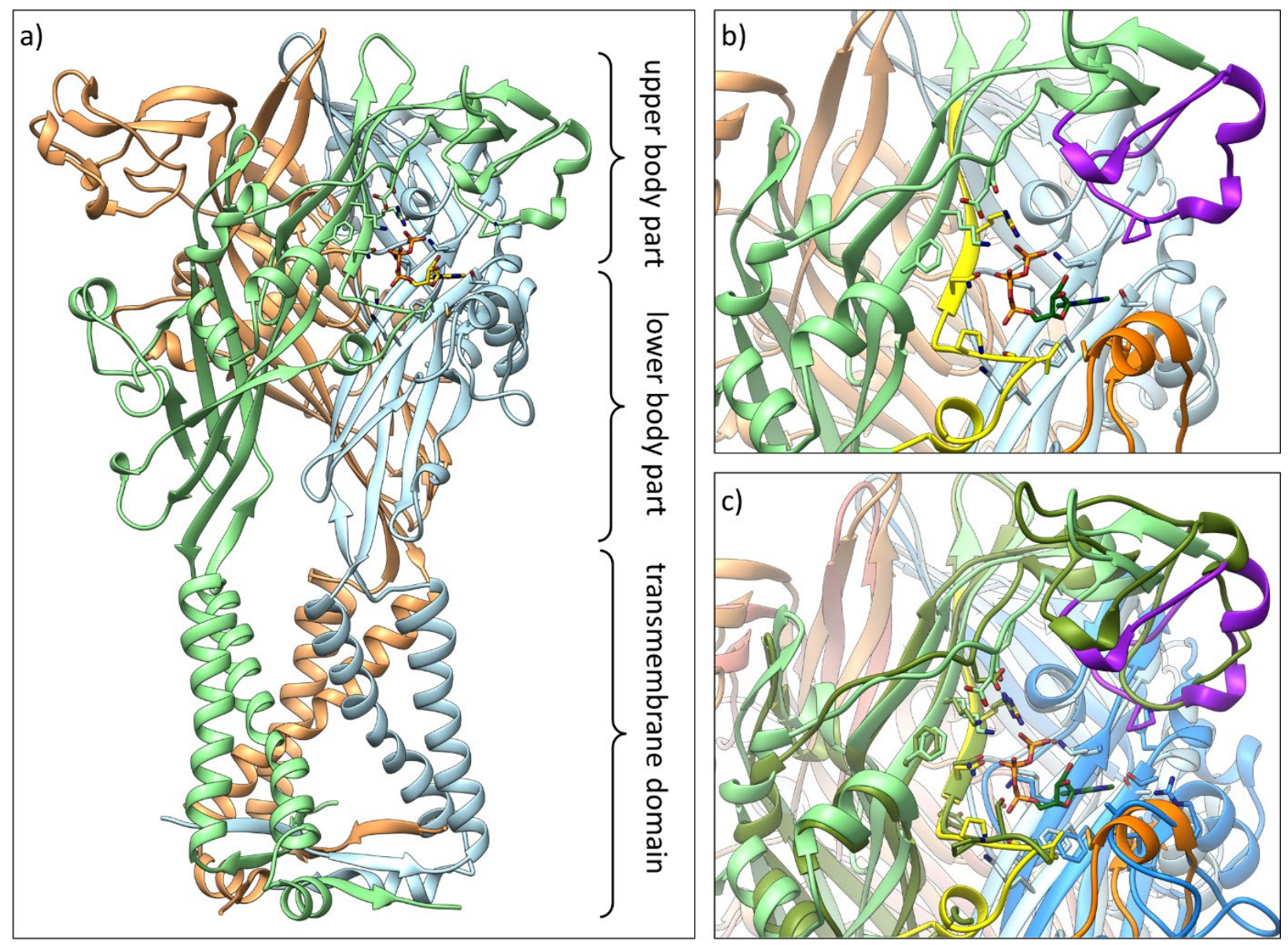

Figure 3: Definition of interacting domain:the human $P 2 X 3$ structure. a) Structural overview of the ATPbound open hP2X3 channel (PDB 5SVK), the coloring indicates the different chains. b/c) Focus on the ATP binding pocket of hP2X3 with bound ATP (b, PDB 5SVK) and overlayed with the open binding pocket (c, PDB 5SVK/5SVJ), the coloring indicates the important binding regions with bound ATP (magenta: head domain, orange: dorsal fin, yellow: left flipper). 
It seems quite obvious, why compound $\mathbf{2 5}$ is inactive on all receptors. The methoxy group in para position at the 2'O-benzoic ester led to a significant clash with the side chains of the head domain (see Figure 5b). The necessary adaptations of the receptor in the minimization step are so fundamental that they are very unlikely in the context of an induced-fit mechanism. Therefore, the additional methoxy group does not fit into the binding site in comparison to ATP binding. The unexpected behavior of compound $\mathbf{2 6}$ was already indicated in the previous section and can also be seen in the structural analysis. In all receptors, except P2X7, the dorsal fin loop forms a rather rigid helical structure which leads to steric clashes with the bulky group of $\mathbf{2 6}$ (see Figure 5). In contrast, this loop misses the helical structure in the P2X7 receptor due to a deletion of 4 amino acids in comparison to the other receptors. Without this helical region, this loop is considerably more flexible and can easily adapt to the bulky group during the minimization study. Therefore, it can be expected that the binding pocket closure can still happen inducing the needed conformational changes for opening the $\mathrm{P} 2 \mathrm{X} 7$ receptor. In the other receptors, the needed conformational changes are hampered by the helical structure that is preventing the full closure of the binding pockets. In addition, the P2X7 receptor lacks a Lys in the dorsal fin that closes the binding pocket around the ATP in the other receptors. 


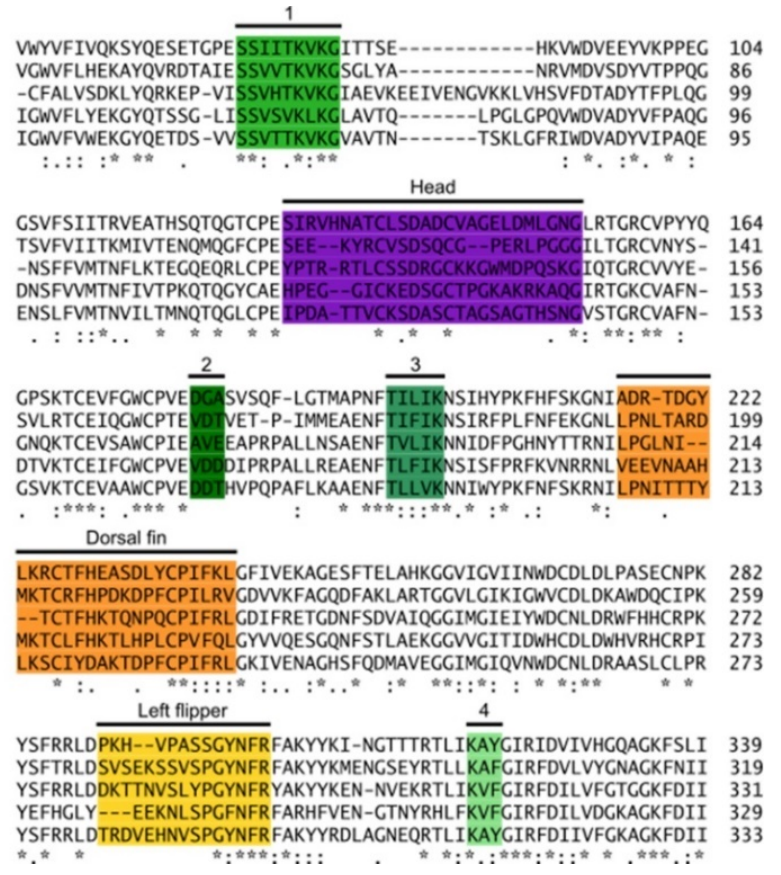

Figure 4: Multiple sequence alignments of different $P 2 X$ ion channels. Relevant parts for ATP binding are named and colored: Different green colors: different ATP binding regions, magenta: head domain, orange: dorsal fin, yellow: left flipper.

Unfortunately, finding an explanation for the results of compound $\mathbf{2 4}$ is less obvious as before. However, the computational analysis shows that compound 24 nicely fits into the P2X4 receptor binding site without major movements of the interaction regions during the minimization. This explains the agonistic effect on the P2X4 receptor. In contrast, in P2X3 receptor, steric clashes can be seen for the 2'-O extension, which most likely lead to the same problem as explained with compound 25. The antagonistic activity of $\mathbf{2 4}$ on P2X2 receptor can be explained by the needed movement of left flipper and dorsa fin during energy minimization. It seems that compound $\mathbf{2 4}$ can bind but is too big for a full closure of the binding pocket that is needed for the opening of the receptor. For the $\mathrm{P} 2 \mathrm{X} 7$ receptor, the modeling study did not reveal an obvious explanation. It can only be speculated that the number of suitable interactions between $\mathbf{2 4}$ and the receptor is too low. 
a)

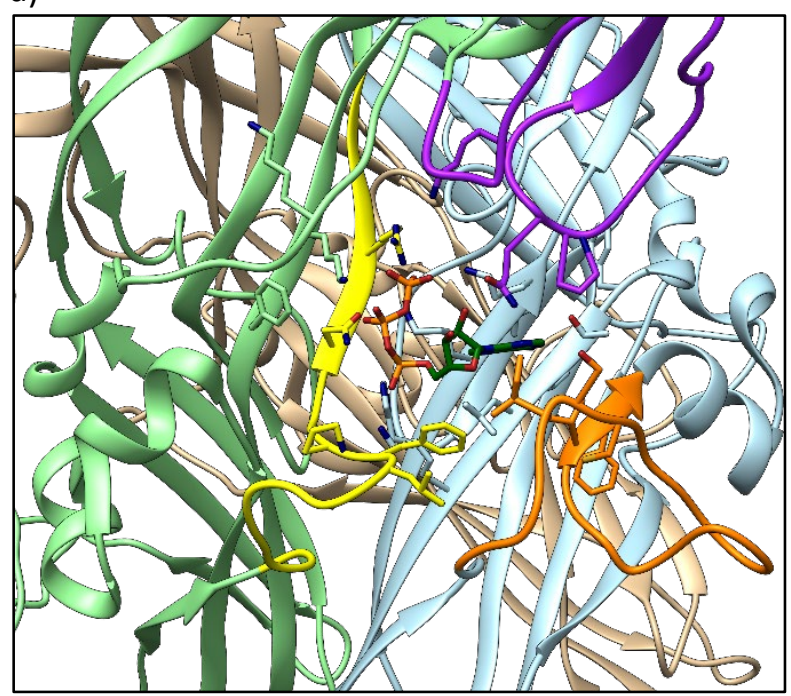

c)

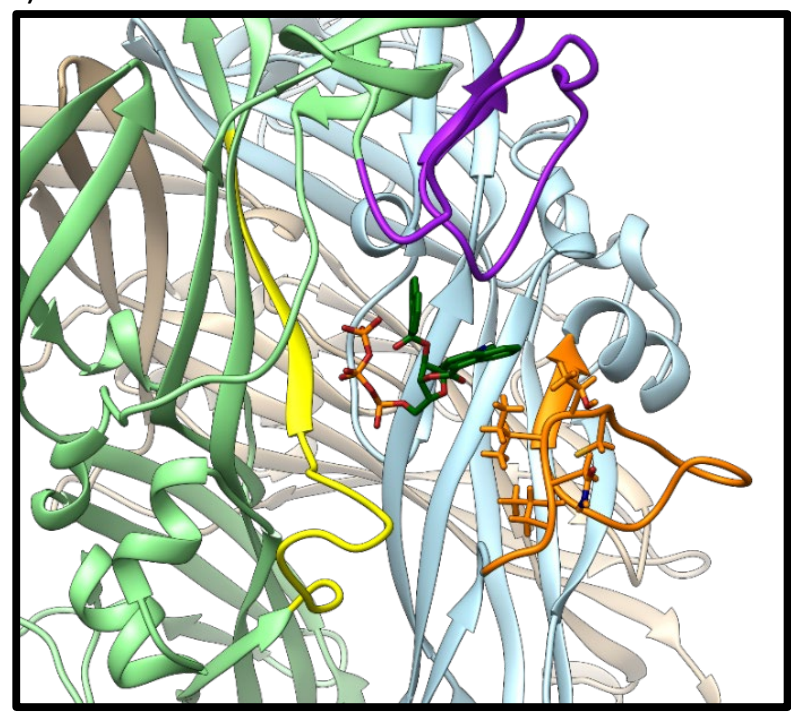

b)

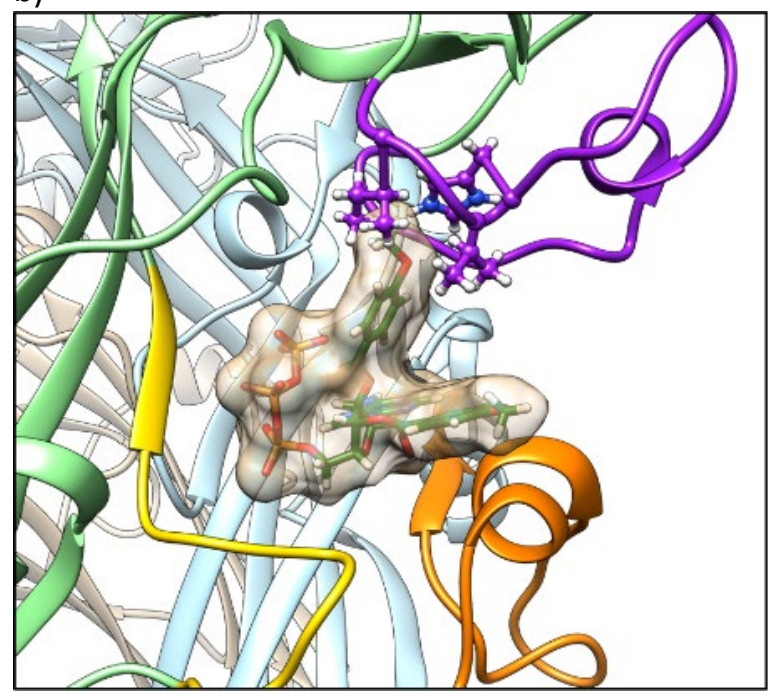

d)

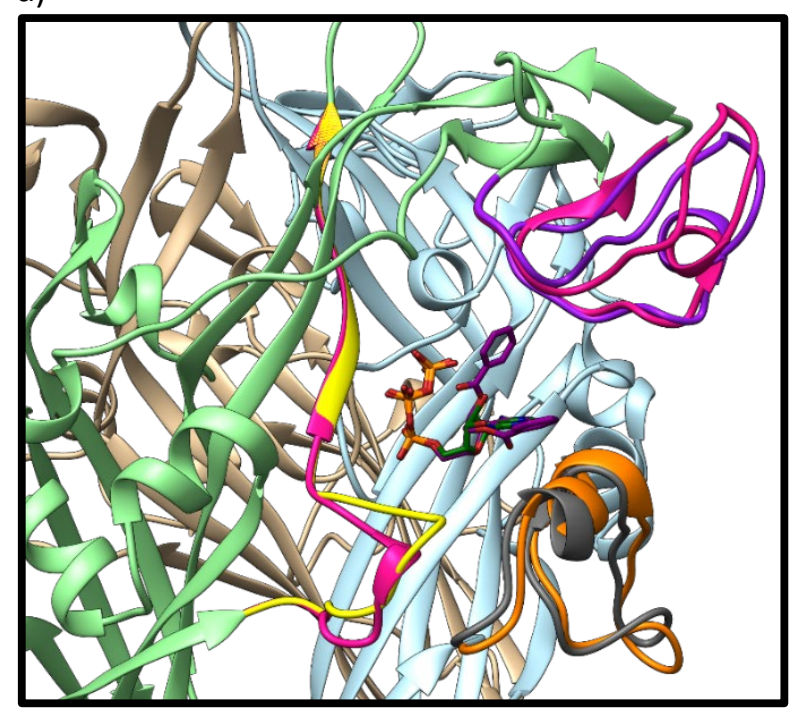

Figure 5: Structural analysis of compounds 24-26 binding to different P2X recptors a) ATP bound P2X7 structure (pdb 6u9w) with irregular dorsal fin loop region (orange). Structural analysis of compounds 24-26 binding to different $\mathrm{P} 2 \mathrm{X}$ receptors (receptor and interaction region coloring as in figure 3 . b) Compound 25 bound the P2X2-model showing a steric clash. c) compound 26 bound to the P2X7 model. d) Compound 24 bound to P2X2-model in comparison to the ATP bound model (grey and pink colored interaction regions).

Based on the composition of the heterotrimer P2X2/3 either a full P2X2 or a full P2X3 ATP binding pocket exists together with two mixed P2X2/3 ATP binding site. For the mixed binding sites, the dorsal fin, or the head domain and left flipper is provided by either a P2X2 or P2X3 chain. This means that at least one mixed binding site must be accessible for compound $\mathbf{2 4}$ depending on which chain is providing a suitable binding region. This can be seen for the hetero-dimer-binding- 
sites, where the P2X2 chain provides the head domain and left flipper, and the P2X3 chain the dorsal fin $(\mathrm{P} 2 \mathrm{X} 2 / 3)$. In this combination, the above-described problems can not be seen and compound 24 fits well into the binding site. For the other heterodimer-binding site, where the P2X3 deliver the head domain (P2X3/2), the same problem as before can be seen. The 2'-O extension has not enough space in the binding site and therefore lead to a movement of the loop in the head domain indicating the compound 24 cannot bind to this heterodimer-binding site. This can explain the unexpected agonistic effect of compound $\mathbf{2 4}$ and this would mean, that one agonistic binding seems to be sufficient for an agonistic effect. As a summary, an agonistic binding can be seen for $\mathrm{P} 2 \mathrm{X} 2 / 3$ heterodimer binding site, no binding for $\mathrm{P} 2 \mathrm{X} 3 / 2$ and a $\mathrm{P} 2 \mathrm{X} 3$ binding sites or a antagonistic binding for the $\mathrm{P} 2 \mathrm{X} 2$ binding site. So, the $\mathrm{P} 2 \mathrm{X} 2 / 3$ agonistic binding must be dominant in this case and the exact composition of the hetero-trimer seems irrelevant.

\section{Conclusion}

A series of 30 ATP derivatives varied at the nucleobase and the ribose portion were evaluated for their agonistic and antagonistic activity across six different P2X receptor subtypes (P2X1RP2X4R, P2X2/3R, P2X7R). Structure-activity relationships revealed ways for the development of highly selective orthosteric P2X receptor ligands. The 2-chloro-3-trifluoromethylbenzoic ester 17 acts as a pan P2X receptor agonist outperforming BzBzATP (3) in its agonistic activity as well as photostability. The adamantyl ester 23 is a highly P2X4 and P2X7 selective agonist. Introducing a methoxy function at 2'-position as in compound 29 leads to a complete loss of P2X receptor activity, while stereoinversion of the 2' stereocenter as in $\mathbf{3 0}$ induces P2X4 receptor activity and selectivity. The P2X7 receptor is most sensitive towards modifications at the nucleobase. The introduction of the azide function at the 8-position of the nucleobase abolishes P2X receptor activity (38) completely, while the introduction of a carbonyl function as in compound 39 leads to $\mathrm{P} 2 \mathrm{X} 3$ receptor selectivity. $\mathrm{N}^{6}$-alkylation leads to $\mathrm{P} 2 \mathrm{X} 2 / 3$ and $\mathrm{P} 2 \mathrm{X} 3$ receptor preference. In 
contradiction to the common assumption of the requirement of at least one free hydroxy group at 2'- or 3'-position of the ribose moiety for the agonistic activity of ATP derivatives at P2X receptors, we could demonstrate that in fact, the SARs at the orthosteric binding site are more complex. The bisbenzoyl ester derivative 24 displayed an agonism at $\mathrm{P} 2 \mathrm{X} 2 / 3$ and $\mathrm{P} 2 \mathrm{X} 4$ receptors while acting as an antagonist at $\mathrm{P} 2 \mathrm{X} 2$ receptors. The bis ester $\mathbf{2 6}$ acted, depending on the assay, as a superagonist or partial agonist at $\mathrm{P} 2 \mathrm{X} 7$ receptors while showing an antagonistic profile at all other $\mathrm{P} 2 \mathrm{X}$ receptor subtypes. The multiple sequence alignment clearly showed that the $\mathrm{P} 2 \mathrm{X} 7$ receptor has a unique deletion of four amino acids in the important dorsal fin region. The detailed computational analysis indicates that this deletion leads to a more flexible dorsal fin region in the P2X7 receptor tolerating more bulkier substituents, as seen in compound $\mathbf{2 6}$. This particular profile makes compound 26 an exciting pharmacological tool compound for investigating P2X7 receptor agonism while silencing the activity of all other P2X receptor subtypes.

Altogether the results of this study will improve our understanding of the orthosteric binding site of the $\mathrm{P} 2 \mathrm{X}$ receptors and advance the development of further subtype-selective, orthosteric P2X receptor agonists and antagonists.

\section{Experimental section}

\section{Chemistry General}

Compounds 27-41 were purchased from Jena Bioscience. Unless otherwise noted, moisturesensitive reactions were conducted under dry nitrogen. Flash column chromatography (fc): Silica gel 60, 40-64 $\mu \mathrm{m}$; parentheses include: diameter of the column, length of the column, fraction size, eluent, $R_{f}$ value. Melting point: melting point apparatus Stuart Scientific ${ }^{\circledR}$ SMP 3 , uncorrected. IR: IR spectrophotometer FT-ATR-IR (Jasco®). ${ }^{1} \mathrm{H}$ NMR (400 MHz): Unity Mercury Plus 400 spectrometer (Varian®), AV400 (Bruker®), JEOL JNM-ECA-400. ${ }^{13} \mathrm{C}$ NMR (100 MHz): Unity Mercury plus 400 spectrometer (Varian®) JEOL JNM-ECA-400; $\delta$ in ppm relative to tetramethylsilane; coupling constants are given with $0.5 \mathrm{~Hz}$ resolution, the assignments of ${ }^{13} \mathrm{C}$ and 
${ }^{1} \mathrm{H}$ NMR signals were supported by $2 \mathrm{D}$ NMR techniques; $\mathrm{MS}$ : $\mathrm{APCl}=$ atmospheric pressure chemical ionization, $\mathrm{EI}=$ electron impact, $\mathrm{ESI}=$ electro-spray ionization: MicroTof (Bruker Daltronics, Bremen), calibration with sodium formate clusters before measurement. All solvents were of analytical grade quality and demineralized water was used. HPLC solvents were of gradient grade quality, and ultrapure water was used. All HPLC eluents were degassed by sonication prior to use. HPLC Purity: Equipment: UV-detector: UltiMate 3000 variable Wavelength Detector; autosampler: UltiMate 3000; pump: Ultimate 3000; degasser: Ultimate 3000: data acquisition: Chromeleon Client 8.0.0 (Dionex Corpor.). Method: column: guard column: Zorbax SB-Aq 12.5x4.6 mm catridge, column: Zorbax SB-Aq StableBond analytical 150x4.6 mm, flow rate: $1.00 \mathrm{~mL} / \mathrm{min}$; injection volume: $5.0 \mu \mathrm{L}$; detection at $\lambda=210 \mathrm{~nm}$; Method $\mathrm{A}$ : solvents: $A$ : Tetrabutylammonium phosphate buffer $(5 \mathrm{mM})$ in $\mathrm{H}_{2} \mathrm{O}, \mathrm{B}: \mathrm{CH}_{3} \mathrm{CN}$, gradient elution: $(\mathrm{A} \%)$ : 0-20 100 to $90 \%, 20-30$ min: gradient from $90 \%$ to $100 \%$. Method B: solvents: A: Tetrabutylammonium phosphate buffer $(5 \mathrm{mM})$ in $\mathrm{H}_{2} \mathrm{O}, \mathrm{B}: \mathrm{CH}_{3} \mathrm{CN}$, gradient elution: (A \%): 0-20 min 80 to 20\%, 20-30 min: gradient from $20 \%$ to $80 \%$. Semi-preparative HPLC was used to purify the compounds. Equipment: UV-detector: UltiMate VWD-3400RS variable Wavelength Detector; manual sampler injector valve for UltiMate 3000 (800 $\mu \mathrm{L}$ sample loop); pump: UltiMate LPG-3400SD; degasser: UltiMate LPG-3400SD; fraction collector: UltiMate AFC-3000; data acquisition: Chromeleon Client 6.8.0 (Dionex Corpor.). The methods (A) to (D) were mainly applied. If further modifications of methods $(A)$ to $(D)$ were required, the detailed procedure is given in the experimental part. Method RP-HPLC (A): column: guard column: Agilent technologies, PursuitTM C18, 30x21.2 mm, $5 \mu \mathrm{m}$, column: Agilent technologies, Polaris ${ }^{\mathrm{TM}} \mathrm{C} 18-\mathrm{A}, 250 \times 21.2 \mathrm{~mm}, 5 \mu \mathrm{m}$. flow rate: $5.00 \mathrm{~mL} / \mathrm{min}$; injection volume: $400-800 \mu \mathrm{L}$; detection at $\lambda=254$, 280, $230 \mathrm{~nm}$; Method RP-HPLC A: solvents: A: $\mathrm{CH}_{3} \mathrm{CN}, \mathrm{B}$ : Triethylammonium acetate $(0.1 \mathrm{M}, \mathrm{pH}=7)$ in water, gradient elution: $(\mathrm{A} \%):$ 1-30 $\min 10$ to $30 \%, 30-31 \min 30$ to $100 \%, 31-40 \min 100$ to $10 \%, 41-51 \min 10 \%$. Method RP-HPLC $\mathrm{B}: \mathrm{A}: \mathrm{CH}_{3} \mathrm{CN}, \mathrm{B}$ : Triethylammonium acetate $(0.1 \mathrm{M}, \mathrm{pH}=7)$ in water, gradient elution: $(\mathrm{A} \%)$ : 0-1 $\min 20 \%, 1-35 \min 20$ to $35 \%, 35-40 \min 35 \%, 40-41 \min 35$ to $100,41-50100 \%, 51-59100$ to 
20\%. Method RP-HPLC C: A: $\mathrm{CH}_{3} \mathrm{CN}, \mathrm{B}$ : Triethylammonium acetate $(0.1 \mathrm{M}, \mathrm{pH}=7)$ in water, gradient elution: (A \%): 0-1 $\min 15 \%, 1-25 \min 15$ to $40 \%, 25-35 \min 40 \%, 35-36$ min 40 to 100 , 40-45 100 to $15 \%, 45-51$ 15\%. Method RP-HPLC D: A: $\mathrm{CH}_{3} \mathrm{CN}$, B: Triethylammonium acetate $(0.1 \mathrm{M}, \mathrm{pH}=7)$ in water, gradient elution: $(\mathrm{A} \%)$ : 0-1 $\min 20 \%, 1-20 \min 20$ to $40 \%, 20-30 \min$ $40 \%, 30-31 \min 40$ to $100 \%, 31-40100 \%, 40-41100$ to $20 \%, 41-5020 \%$. Thin-layer chromatography was conducted with silica gel $F_{254}$ on aluminium plates in a saturated chamber at room temperature. The spots were visualized using UV light $(254 \mathrm{~nm})$ or reagents such as cerium molybdate dipping bath with additional heating using a standard heat gun. Hence the retention factor values strongly depend on the temperature, the chamber saturation and exact ratio of components of the eluent (highly volatile); the given retention factor values represent just approximate values. Flash column chromatography was conducted with silica gel 600 (40 - $63 \mu \mathrm{m}$, Macherey-Nagel).

\section{Nomenclature of synthesized ATP-derivatives}

For simplification, the retained names derived from ATP (1) were used. Otherwise, using the preferred IUPAC names, based on the substitutive nomenclature principle, would change the numbering of the ribose moiety due to the higher priority of the benzoic esters.

\section{General procedure for the synthesis of ATP-esters}

A solution of CDI (3 eq.) and the corresponding carboxylic acid (2 eq.) in dry DMF (2 mL) was stirred for $1 \mathrm{~h}$ at room temperature. Then ATP (1 eq.) in water $(2 \mathrm{~mL})$ was added at room temperature, and the mixture was allowed to stir at room temperature for 1-7 d. Samples were withdrawn at $1 \mathrm{~d}$ interval for LC-MS to check the disappearance of ATP and monitor the desired ester formation. Toluene $(25 \mathrm{~mL})$ was added on the disappearance of ATP, and the solution was evaporated to dryness $\left(40^{\circ} \mathrm{C}\right)$. The residue was resuspended in acetone $(25 \mathrm{~mL})$, sonicated, and filtered two times. The residue was dissolved in water, freeze-dried, and then stored at $-20{ }^{\circ} \mathrm{C}$. The mixture of monosubstituted and disubstituted ATP esters was separated by ion-exchange 
chromatography on Sephadex LH. Fractions containing the product were pooled and freeze-dried. The compound was then purified by RP-HPLC. Suitable fractions were pooled and lyophilized to obtain the final product as glassy solid.

\section{Synthesis procedures}

2'-O-Benzoyl-adenosine 5'-(tetrahydrogene triphosphate) and 3'-O-Benzoyl-adenosine 5'(tetrahydrogene triphosphate) (10)

The mixture of the products was obtained as colorless solid after lyophilization (3.5 eq. $\mathrm{Et}_{3} \mathrm{~N}$-salt [965,46 g/mol], 0.6:1 [A:B], $71 \mathrm{mg}, 73.5 \mu \mathrm{mol}, 7.4 \%$ ). $R_{t}$ (Sephadex-C): $11.7 \mathrm{~min} . R_{t}$ (RP-HPLCA): $22.7 \mathrm{~min}$. Purity (HPLC-A): $98 \%\left(R_{t}=12.9 \mathrm{~min}[83 \%\right.$ ] and $14.2 \mathrm{~min}[15 \%])$. LC-MS: $\mathrm{m} / \mathrm{z}=$ calcd. for $\mathrm{C}_{17} \mathrm{H}_{19} \mathrm{~N}_{5} \mathrm{O}_{14} \mathrm{P}_{3} 610.0$, found $610.0[\mathrm{M}-\mathrm{H}]^{-}\left(R_{t}=1.94 \mathrm{~min}\right)$. Exact mass $(\mathrm{ESI}): \mathrm{m} / \mathrm{z}=$ calcd. for $\mathrm{C}_{17} \mathrm{H}_{19} \mathrm{~N}_{5} \mathrm{O}_{14} \mathrm{P}_{3} 610.0147$, found $610.0137[\mathrm{M}-\mathrm{H}]^{-} .{ }^{1} \mathrm{H}$ NMR $\left(\mathrm{D}_{2} \mathrm{O}, 400 \mathrm{MHz}\right): \delta(\mathrm{ppm})=8.61(\mathrm{~s}$, $\left.1 \mathrm{H}, 8-\mathrm{CH}_{\text {purine-B }}\right), 8.55\left(\mathrm{~s}, 0.6 \mathrm{H}, 8-\mathrm{CH}_{\text {purine-A}}\right), 8.21\left(\mathrm{~s}, 1 \mathrm{H}, 2-\mathrm{CH}_{\text {purine-B }}\right), 8.17\left(\mathrm{~s}, 0.6 \mathrm{H}, 2-\mathrm{CH}_{\text {purine-A}}\right)$, 8.14-8.09 (m, 2H, 2,6-CH $\left.\mathrm{CH}_{\text {phenyl-B }}\right), 8.04-7.97\left(\mathrm{~m}, 1.2 \mathrm{H}, 2,6-\mathrm{CH}_{\text {phenyl-A }}\right), 7.73-7.67\left(\mathrm{~m}, 1 \mathrm{H}, 4-\mathrm{CH}_{\text {phenyl- }}\right.$

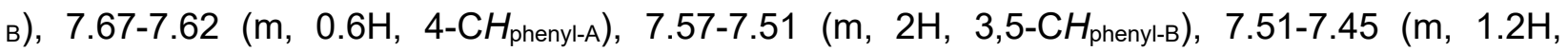
3,5- $\mathrm{CH}_{\text {phenyl-A) }}, 6.45$ (dd, $\left.J=4.6,2.9 \mathrm{~Hz}, 0.6 \mathrm{H}, 1 '-\mathrm{CH}_{\mathrm{A}}\right), 6.30$ (dd, $J=7.6,3.4 \mathrm{~Hz}, 1 \mathrm{H}, 1^{\prime}-\mathrm{CH}$ ), 5.84$5.77\left(\mathrm{~m}, 1.6 \mathrm{H}, 2^{\prime}-\mathrm{CH}_{\mathrm{A}}, 3^{\prime}-\mathrm{CH}_{\mathrm{B}}\right), 5.18$ (td, $\left.J=7.2,5.2 \mathrm{~Hz}, 1 \mathrm{H}, 2^{\prime}-\mathrm{CH}_{\mathrm{B}}\right), 4.94\left(\mathrm{t}, J=5.5 \mathrm{~Hz}, 0.6 \mathrm{H}, 3^{\prime}-\right.$ $\left.\mathrm{CH}_{\mathrm{A}}\right), 4.73-4.69\left(\mathrm{~m}, 1 \mathrm{H}, 4^{\prime}-\mathrm{CH}_{\mathrm{B}}\right), 4.56-4.50\left(\mathrm{~m}, 0.6 \mathrm{H}, 4^{\prime}-\mathrm{CH}_{\mathrm{A}}\right), 4.45-4.37\left(\mathrm{~m}, 2.2 \mathrm{H}, 5^{\prime}-\mathrm{CHH}_{\mathrm{B}}, 5^{\prime}-\right.$ $\left.\mathrm{CH}_{2 \mathrm{~A}}\right), 4.35-4.29\left(\mathrm{~m}, 1 \mathrm{H}, 5^{\prime}-\mathrm{CHH}_{\mathrm{B}}\right), 3.17\left(\mathrm{q}, J=7.3 \mathrm{~Hz}, 34 \mathrm{H}, \mathrm{CH}_{2 \mathrm{NEt} 3}\right), 1.26(\mathrm{t}, J=7.3 \mathrm{~Hz}, 50 \mathrm{H}$,

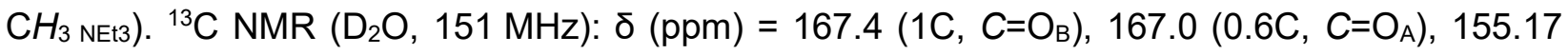

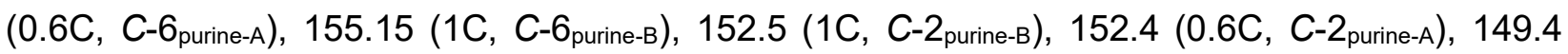
(C-4 purine-B), 148.6 (0.6C, C-4 purine-A), 140.1 (0.6C, C-8 purine-A), 140.0 (1C, C-8 purine-B) $_{\text {B }} 134.3$ (0.6C,

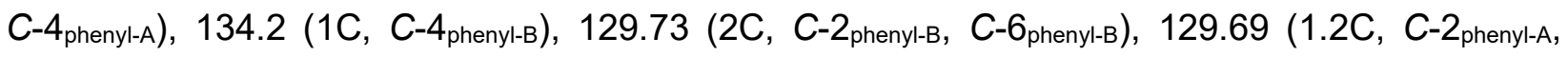

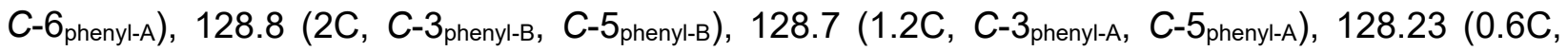
$\left.C-1_{\text {phenyl-A) }}\right), 128.19$ (C-1 $\left.1_{\text {phenyl-B }}\right), 118.4$ (1.6C, C-5 purine-A, $\left.C-5_{\text {purine-B }}\right), 86.0$ (d, J = 2.1 Hz, 1C, $C-1_{\text {B) }}$ ), $85.9\left(\mathrm{~d}, J=2.4 \mathrm{~Hz}, 0.6 \mathrm{C}, C-1^{\prime} \mathrm{A}\right), 83.6\left(\mathrm{~d}, J=9.3 \mathrm{~Hz}, 0.6 \mathrm{C}, C-4{ }_{\mathrm{A}}\right), 82.4\left(\mathrm{~d}, J=9.2 \mathrm{~Hz}, 1 \mathrm{C}, C-4_{\mathrm{B}}^{\prime}\right.$ ), $76.8\left(0.6 \mathrm{C}, C-2^{\prime} \mathrm{A}\right), 74.6\left(1 \mathrm{C}, \mathrm{C}-3_{\mathrm{B}}^{\prime}\right), 73.2\left(1 \mathrm{C}, \mathrm{C}-2^{\prime}{ }_{\mathrm{B}}\right), 68.7\left(0.6 \mathrm{C}, \mathrm{C}-3^{\prime}{ }_{\mathrm{A}}\right), 65.7$ (d, J = $5.2 \mathrm{~Hz}, 1 \mathrm{C}$, $\left.C-5{ }_{B}{ }_{B}\right), 64.8\left(\mathrm{~d}, J=5.8 \mathrm{~Hz}, 0.6 \mathrm{C}, C-5^{\prime}{ }_{\mathrm{A}}\right), 46.7\left(16.7 \mathrm{C}, 1 \mathrm{C}, \mathrm{CH}_{2 \mathrm{NEt} 3}\right), 8.3\left(16.7 \mathrm{C}, \mathrm{CH}_{3 \mathrm{NEt}}\right) .{ }^{31} \mathrm{P}$ NMR $\left(162 \mathrm{MHz}, \mathrm{D}_{2} \mathrm{O} / \mathrm{D}_{3} \mathrm{PO}_{4}\right): \delta(\mathrm{ppm})=-10.7\left(0.6 \mathrm{P}, \beta-\mathrm{P}_{\mathrm{A}}\right),-10.9\left(1 \mathrm{P}, \beta-\mathrm{P}_{\mathrm{B}}\right),-11.5\left(0.6 \mathrm{P}, \alpha-\mathrm{P}_{\mathrm{A}}\right),-11.6$ $\left(1 \mathrm{P}, \alpha-\mathrm{P}_{\mathrm{B}}\right),-23.3\left(1.6 \mathrm{P}, \mathrm{y}-\mathrm{P}_{\mathrm{A}, \mathrm{B}}\right)$. 
2'-O-(4-Methoxybenzoyl)-adenosine 5'-(tetrahydrogene triphosphate) and 3'-O-(4Methoxybenzoyl)-adenosine 5'-(tetrahydrogene triphosphate) (11)

The mixture of the products was obtained as colorless solid after lyophilization $\left(2.5 \mathrm{eq}\right.$. Et $\mathrm{t}_{3} \mathrm{~N}$-salt [894,30 g/mol], 0.6:1 [A:B], $30 \mathrm{mg}, 34 \mu \mathrm{mol}, 3.4 \%$ ). $R_{t}$ (Sephadex-B): $12.7 \mathrm{~min} . R_{t}(\mathrm{RP}-\mathrm{HPLC}-\mathrm{A})$ : 24.4 min. Purity (HPLC-A): $95 \%\left(R_{t}=12.9 \mathrm{~min}\right.$ [86 \%] and $14.3 \mathrm{~min}$ [9 \%]). LC-MS: $\mathrm{m} / \mathrm{z}=$ calcd. for $\mathrm{C}_{18} \mathrm{H}_{21} \mathrm{~N}_{5} \mathrm{O}_{15} \mathrm{P}_{3} 640.0$, found $640.0[\mathrm{M}-\mathrm{H}]^{-}\left(R_{t}=2.73 \mathrm{~min}\right)$. Exact mass $(\mathrm{ESI}): \mathrm{m} / \mathrm{z}=$ calcd. for $\mathrm{C}_{18} \mathrm{H}_{21} \mathrm{~N}_{5} \mathrm{O}_{15} \mathrm{P}_{3} 640.0252$, found $640.0256[\mathrm{M}-\mathrm{H}]^{-} .{ }^{1} \mathrm{H}$ NMR $\left(\mathrm{D}_{2} \mathrm{O}, 600 \mathrm{MHz}\right): \delta(\mathrm{ppm})=8.64(\mathrm{~s}, 1 \mathrm{H}$, 8- $\left.\mathrm{CH}_{\text {purine-B}}\right), 8.60\left(\mathrm{~s}, 0.6 \mathrm{H}, 8-\mathrm{CH}_{\text {purine-A }}\right), 8.34\left(\mathrm{~s}, 1.6 \mathrm{H}, 2-\mathrm{CH}_{\text {purine-B, }} 2-\mathrm{CH}_{\text {purine-A}}\right), 7.93(\mathrm{~d}, \mathrm{~J}=7.9 \mathrm{~Hz}$, $\left.2 \mathrm{H}, 2,6-\mathrm{CH}_{\text {phenyl-B}}\right), 7.85\left(\mathrm{~d}, J=8.3 \mathrm{~Hz}, 1.2 \mathrm{H}, 2,6-\mathrm{CH}_{\text {phenyl-A) }}\right), 6.92\left(\mathrm{~d}, J=8.3 \mathrm{~Hz}, 2 \mathrm{H}, 3,5-\mathrm{CH}_{\text {phenyl- }}\right.$ в), $6.89\left(\mathrm{~d}, J=8.3 \mathrm{~Hz}, 1.2 \mathrm{H}, 3,5-\mathrm{CH}_{\text {phenyl-A) }}\right) 6.36\left(\mathrm{~d}, J=3.9 \mathrm{~Hz}, 0.6 \mathrm{H}, 1 '-\mathrm{CH}_{\mathrm{A}}\right), 6.24$ (d, J = $7.5 \mathrm{~Hz}$, $\left.1 \mathrm{H}, 1^{\prime}-\mathrm{CH}_{\mathrm{B}}\right), 5.67\left(\mathrm{t}, J=4.5 \mathrm{~Hz}, 0.6 \mathrm{H}, 2^{\prime}-\mathrm{CH}_{\mathrm{A}}\right), 5.64\left(\mathrm{~d}, J=5.2 \mathrm{~Hz}, 1 \mathrm{H}, 3^{\prime}-\mathrm{CH}_{\mathrm{B}}\right), 5.06-5.02(\mathrm{~m}, 1 \mathrm{H}$, 2'-CH $\left.\mathrm{B}_{\mathrm{B}}\right), 4.89-4.86\left(\mathrm{~m}, 0.6 \mathrm{H}, 3\right.$ '- $\left.\mathrm{CH}_{\mathrm{A}}\right), 4.66\left(\mathrm{~m}, 1 \mathrm{H}, 4\right.$ '- $\left.\mathrm{CH}_{\mathrm{B}}\right), 4.52-4.49\left(\mathrm{~m}, 0.6 \mathrm{H}, 4{ }^{\prime}-\mathrm{CH}_{\mathrm{A}}\right), 4.46(\mathrm{~d}$, $\left.J=11.3 \mathrm{~Hz}, 0.6 \mathrm{H}, 5^{\prime}-\mathrm{CHH}_{\mathrm{A}}\right), 4.43-4.32\left(\mathrm{~m}, 2.6 \mathrm{H}, 5^{\prime}-\mathrm{CH}_{\mathrm{A}}, 5^{\prime}-\mathrm{CH}_{2 \mathrm{~B}}\right), 3.86\left(\mathrm{~s}, 3 \mathrm{H}, \mathrm{CH}_{3 \mathrm{~B}}\right), 3.82(\mathrm{~s}$,

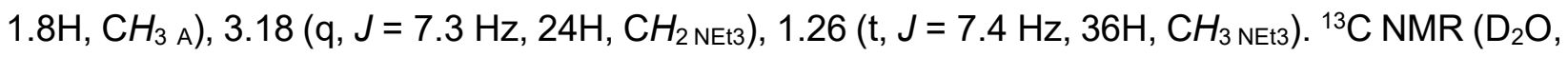
$151 \mathrm{MHz}): \delta(\mathrm{ppm})=167.0\left(1 \mathrm{C}, \mathrm{C}=\mathrm{O}_{\mathrm{B}}\right), 166.4\left(0.6 \mathrm{C}, \mathrm{C}=\mathrm{O}_{\mathrm{A}}\right), 163.7\left(0.6 \mathrm{C}, \mathrm{C}-4_{\text {phenyl-A }}\right), 163.6(1 \mathrm{C}$, C-4 $\left.4_{\text {phenyl-B}}\right), 151.4$ and 151.2 (1.6C, C- $\left.6_{\text {purine-A, }} C-6_{\text {purine-B }}\right), 148.8$ (1C, C-4 $\left.4_{\text {purine-B }}\right), 147.4$ (1.6C, $\left.C-2_{\text {purine-A, }} C-2_{\text {purine-B }}\right), 141.5$ (1.6C, C-8 $\left.8_{\text {purine-A }}, C-8_{\text {purine-B }}\right), 131.95$ (1.2C, C- $\left.2_{\text {phenyl-A }} C-6_{\text {phenyl-A }}\right)$,

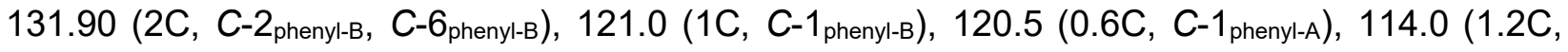

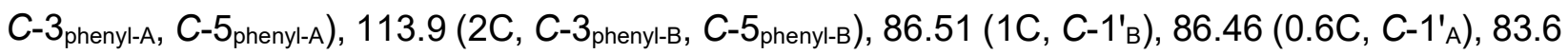
$\left(\mathrm{d}, J=8.7 \mathrm{~Hz}, 0.6 \mathrm{C}, C-4_{\mathrm{A}}^{\prime}\right), 82.8\left(\mathrm{~d}, J=8.8 \mathrm{~Hz}, 1 \mathrm{C}, C-4_{\mathrm{B}}^{\prime}\right), 76.6\left(0.6 \mathrm{C}, C-2_{\mathrm{A}}^{\prime}\right), 74.4\left(1 \mathrm{C}, C-3_{\mathrm{B}}^{\prime}\right)$, 73.8 (1C, C-2'B), 68.5 (0.6C, C-3'A), 65.7 (d, J = 3.6 Hz, 1C, C-5'B), $64.6\left(0.6 \mathrm{C}, C-5_{\mathrm{A}}^{\prime}\right), 55.68$ (1C, $\left.\mathrm{CH}_{3 \mathrm{~B}}\right), 55.65$ (0.6C, $\left.\mathrm{CH}_{3 \mathrm{~A}}\right), 46.7\left(12 \mathrm{C}, \mathrm{CH}_{2} \mathrm{NEt} 3\right), 8.3\left(12 \mathrm{C}, \mathrm{CH}_{3 \mathrm{NEt}}\right) . C-5_{\text {purine-A, }} C-5_{\text {purine-B }}$ and $C-4_{\text {purine-A }}$ could not be seen. ${ }^{31} \mathrm{P}$ NMR $\left(160 \mathrm{MHz}, \mathrm{D}_{2} \mathrm{O}\right): \delta(\mathrm{ppm})=-11.1(2 \mathrm{P}, \alpha-\mathrm{P}, \beta-\mathrm{P}),-22.4(1 \mathrm{P}$, $\mathrm{Y}-\mathrm{P})$.

2'-O-(4-Pentylbenzoyl)-adenosine 5'-(tetrahydrogene triphosphate) and 3'-O-(4-Pentylbenzoyl)adenosine 5'-(tetrahydrogene triphosphate) (12)

The mixture of the products was obtained as colorless solid after lyophilization (2.75 eq. $\mathrm{Et}_{3} \mathrm{~N}$-salt [959.69 g/mol], 0.5:1 [A:B], $4 \mathrm{mg}, 4 \mu \mathrm{mol}, 0.4 \%$ ). $R_{t}$ (RP-HPLC): $33.7 \mathrm{~min}:$ solvent $\mathrm{A}: \mathrm{CH}_{3} \mathrm{CN}$, solvent B: $0.1 \mathrm{M}$ TEAA, 0-1 min: $25 \%$ solvent A, $0.1 \mathrm{~mL} / \mathrm{min} \rightarrow 5 \mathrm{~mL} / \mathrm{min}, 1-20 \mathrm{~min}: 25 \% \rightarrow 40 \%$ solvent $A, 20-30$ min: $40 \%$ solvent $A, 30-31 \mathrm{~min}: 40 \% \rightarrow 100 \%$ solvent $A, 31-40 \mathrm{~min}: 100 \%$ solvent $A, 40-41 \mathrm{~min}: 100 \% \rightarrow 25 \%$ solvent $A, 41-50 \mathrm{~min}: 25 \%$ solvent $A, 5-51 \mathrm{~min}: 25 \%$ solvent A, $5 \mathrm{~mL} / \mathrm{min} \rightarrow 0.1 \mathrm{~mL} / \mathrm{min}$, Injection volume : 400-800 $\mu \mathrm{L}$. Purity (HPLC-B): $96 \%\left(R_{t}=12.2 \mathrm{~min}\right)$. LC-MS: $\mathrm{m} / \mathrm{z}=$ calcd. for $\mathrm{C}_{22} \mathrm{H}_{29} \mathrm{~N}_{5} \mathrm{O}_{14} \mathrm{P}_{3} 680.1$, found $680.2[\mathrm{M}-\mathrm{H}]^{-}\left(R_{t}=6.05 \mathrm{~min}\right)$. Exact mass (ESI): $\mathrm{m} / \mathrm{z}=$ calcd. for $\mathrm{C}_{22} \mathrm{H}_{29} \mathrm{~N}_{5} \mathrm{O}_{14} \mathrm{P}_{3} 680.0929$, found 680.0941 [M-H]- ${ }^{1} \mathrm{H}$ NMR $\left(\mathrm{D}_{2} \mathrm{O}, 600 \mathrm{MHz}\right)$ : 
$\delta(\mathrm{ppm})=8.67\left(\mathrm{~s}, 1 \mathrm{H}, 8-\mathrm{CH}_{\text {purine-B }}\right), 8.61\left(\mathrm{~s}, 0.5 \mathrm{H}, 8-\mathrm{CH}_{\text {purine-A }}\right), 8.31\left(\mathrm{~m}, 1.5 \mathrm{H}, 2-\mathrm{CH}_{\text {purine-A }}, 2-\mathrm{CH}_{\text {purine- }}\right.$ в), 7.98-7.84 (m, 3H, 2,6-CH $\left.\mathrm{CH}_{\text {phyl-A, }} 2,6-\mathrm{CH}_{\text {phenyl-B }}\right), 7.34-7.16\left(\mathrm{~m}, 3 \mathrm{H}, 3,5-\mathrm{CH}_{\text {phenyl-A, }} 3,5-\mathrm{CH}_{\text {phenyl-B}}\right)$, $6.34\left(\mathrm{~m}, 0.5 \mathrm{H}, 1^{\prime}-\mathrm{CH}_{\mathrm{A}}\right), 6.19\left(\mathrm{~m}, 1 \mathrm{H}, 1^{\prime}-\mathrm{CH}_{\mathrm{B}}\right), 5.75\left(\mathrm{~m}, 0.5 \mathrm{H}, 2^{\prime}-\mathrm{CH}_{\mathrm{A}}\right), 5.69\left(\mathrm{~m}, 1 \mathrm{H}, 3^{\prime}-\mathrm{CH}_{\mathrm{B}}\right), 5.05$ $\left(\mathrm{m}, 1 \mathrm{H}, 2^{\prime}-\mathrm{CH}_{\mathrm{B}}\right), 4.91\left(\mathrm{~m}, 0.5 \mathrm{H}, 3^{\prime}-\mathrm{CH}_{\mathrm{A}}\right), 4.58\left(\mathrm{~m}, 1 \mathrm{H}, 4{ }^{\prime}-\mathrm{CH}_{\mathrm{B}}\right), 4.50-4.43\left(\mathrm{~m}, 1 \mathrm{H}, 4^{\prime}-\mathrm{CH}_{\mathrm{A}}, 5^{\prime}-\mathrm{CH}_{\mathrm{A}}\right)$,

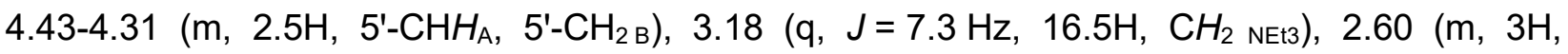
$\left.\mathrm{CH}_{2} \mathrm{CH}_{2} \mathrm{CH}_{2} \mathrm{CH}_{2} \mathrm{CH}_{3 \mathrm{~A}}, \quad \mathrm{CH}_{2} \mathrm{CH}_{2} \mathrm{CH}_{2} \mathrm{CH}_{2} \mathrm{CH}_{3 \mathrm{~B}}\right), \quad 1.54 \quad\left(\mathrm{~m}, \quad 3 \mathrm{H}, \quad \mathrm{CH}_{2} \mathrm{CH}_{2} \mathrm{CH}_{2} \mathrm{CH}_{2} \mathrm{CH}_{3} \mathrm{~A}\right.$, $\mathrm{CH}_{2} \mathrm{CH}_{2} \mathrm{CH}_{2} \mathrm{CH}_{2} \mathrm{CH}_{3 \mathrm{~B}}$ ), $\quad 1.26$ (t, $J=7.3 \mathrm{~Hz}, \quad 27.75 \mathrm{H}, \quad \mathrm{CH}_{3 \mathrm{NEt} 3}, \quad \mathrm{CH}_{2} \mathrm{CH}_{2} \mathrm{CH}_{2} \mathrm{CH}_{2} \mathrm{CH}_{3} \mathrm{~A}$, $\mathrm{CH}_{2} \mathrm{CH}_{2} \mathrm{CH}_{2} \mathrm{CH}_{2} \mathrm{CH}_{3 \mathrm{~B}}$ ), 1.22-1.16 (m, 3H, $\mathrm{CH}_{2} \mathrm{CH}_{2} \mathrm{CH}_{2} \mathrm{CH}_{2} \mathrm{CH}_{3}$ A, $\mathrm{CH}_{2} \mathrm{CH}_{2} \mathrm{CH}_{2} \mathrm{CH}_{2} \mathrm{CH}_{3 \mathrm{~B}}$ ), 0.83$0.76\left(\mathrm{~m}, 4.5 \mathrm{H}, \mathrm{CH}_{2} \mathrm{CH}_{2} \mathrm{CH}_{2} \mathrm{CH}_{2} \mathrm{CH}_{3}\right.$ A, $\left.\mathrm{CH}_{2} \mathrm{CH}_{2} \mathrm{CH}_{2} \mathrm{CH}_{2} \mathrm{CH}_{3 \mathrm{~B}}\right) .{ }^{13} \mathrm{C} \mathrm{NMR}\left(\mathrm{D}_{2} \mathrm{O}, 151 \mathrm{MHz}\right): \delta(\mathrm{ppm})$ $=167.2\left(1.5 \mathrm{C}, C=\mathrm{O}_{\mathrm{A}}, C=\mathrm{O}_{\mathrm{B}}\right), 150.3\left(1.5 \mathrm{C}, C-4_{\text {phenyl-A}}, C-4_{\text {phenyl-B }}\right), 129.93$ (1C,C-2 phenyl-A $\left.C-6_{\text {phenyl-A }}\right)$,

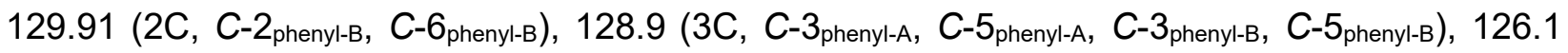
(1C, C-1 phenyl-B), $125.6\left(0.5 \mathrm{C}, C-1_{\text {phenyl-A }}\right), 86.7\left(0.5 \mathrm{C}, C-1_{\mathrm{A}}{ }_{\mathrm{A}}\right), 86.5\left(1 \mathrm{C}, \mathrm{C}-1_{\mathrm{B}}{ }_{\mathrm{B}}\right), 83.5\left(0.5 \mathrm{C}, \mathrm{C}-4_{\mathrm{A}}^{\prime}\right)$, $83.0\left(1 \mathrm{C}, C-4{ }^{\prime}\right), 76.7\left(0.5 \mathrm{C}, C-2^{\prime} \mathrm{A}\right), 74.8\left(1 \mathrm{C}, C-3_{\mathrm{B}}^{\prime}\right), 73.8\left(1 \mathrm{C}, \mathrm{C}-2_{\mathrm{B}}^{\prime}\right), 68.2\left(0.5 \mathrm{C}, \mathrm{C}-3_{\mathrm{A}}^{\prime}\right), 65.8(1 \mathrm{C}$, C-5'B), 64.4 (0.5C, C-5'A), 46.7 (8.25C, $\mathrm{CH}_{2 \mathrm{NEt} 3}$ ), 35.34 (1C, $\mathrm{CH}_{2} \mathrm{CH}_{2} \mathrm{CH}_{2} \mathrm{CH}_{2} \mathrm{CH}_{3 \mathrm{~B}}$ ), 35.31 (0.5C, $\mathrm{CH}_{2} \mathrm{CH}_{2} \mathrm{CH}_{2} \mathrm{CH}_{2} \mathrm{CH}_{3 \mathrm{~A}}$ ), 30.8 (1C, $\mathrm{CH}_{2} \mathrm{CH}_{2} \mathrm{CH}_{2} \mathrm{CH}_{2} \mathrm{CH}_{3 \mathrm{~B}}$ ), 30.7 (0.5C, $\mathrm{CH}_{2} \mathrm{CH}_{2} \mathrm{CH}_{2} \mathrm{CH}_{2} \mathrm{CH}_{3 \mathrm{~A}}$ ), $30.22\left(1 \mathrm{C}, \quad \mathrm{CH}_{2} \mathrm{CH}_{2} \mathrm{CH}_{2} \mathrm{CH}_{2} \mathrm{CH}_{3 \mathrm{~B}}\right), \quad 30.18$ (0.5C, $\left.\mathrm{CH}_{2} \mathrm{CH}_{2} \mathrm{CH}_{2} \mathrm{CH}_{2} \mathrm{CH}_{3} \mathrm{~A}\right), \quad 22.1$ (1C, $\mathrm{CH}_{2} \mathrm{CH}_{2} \mathrm{CH}_{2} \mathrm{CH}_{2} \mathrm{CH}_{3 \mathrm{~B}}$ ), $22.0\left(0.5 \mathrm{C}, \mathrm{CH}_{2} \mathrm{CH}_{2} \mathrm{CH}_{2} \mathrm{CH}_{2} \mathrm{CH}_{3 \mathrm{~A}}\right.$ ), 13.5 (1C, $\mathrm{CH}_{2} \mathrm{CH}_{2} \mathrm{CH}_{2} \mathrm{CH}_{2} \mathrm{CH}_{3 \mathrm{~B}}$ ), 13.4 (0.5, $\mathrm{CH}_{2} \mathrm{CH}_{2} \mathrm{CH}_{2} \mathrm{CH}_{2} \mathrm{CH}_{3 \mathrm{~A}}$ ), 8.3 (8.25C, $\mathrm{CH}_{3 \mathrm{NEt} 3}$ ). Signals of the purine C-atoms could not be seen.

2'-O-(3-Methylbenzoyl)-adenosine 5'-(tetrahydrogene triphosphate) and 3'-O-(3-Methylbenzoyl)adenosine 5'-(tetrahydrogene triphosphate) (13)

The mixture of the products was obtained as colorless solid after lyophilization (3.2 eq. $\mathrm{Et}_{3} \mathrm{~N}$-salt [949.13 g/mol], 0.6:1 [A:B], $20 \mathrm{mg}, 21 \mu \mathrm{mol}, 2 \%$ ). $R_{t}$ (Sephadex-A): $12.6 \mathrm{~min} . R_{t}$ (RP-HPLC-B): 32.5 min. Purity (HPLC-A): $>99 \%\left(R_{t}=12.5 \mathrm{~min}\right)$. LC-MS: $\mathrm{m} / \mathrm{z}=$ calcd. for $\mathrm{C}_{18} \mathrm{H}_{21} \mathrm{~N}_{5} \mathrm{O}_{14} \mathrm{P}_{3} 624.0$, found $624.0[\mathrm{M}-\mathrm{H}]^{-}\left(R_{t}=5.62 \mathrm{~min}\right)$. Exact mass $(\mathrm{ESI}): \mathrm{m} / \mathrm{z}=$ calcd. for $\mathrm{C}_{18} \mathrm{H}_{21} \mathrm{~N}_{5} \mathrm{O}_{14} \mathrm{P}_{3} 624.0303$, found $624.0300[\mathrm{M}-\mathrm{H}]^{-} .{ }^{1} \mathrm{H}$ NMR $\left(\mathrm{D}_{2} \mathrm{O}, 400 \mathrm{MHz}\right): \delta(\mathrm{ppm})=8.60\left(\mathrm{~s}, 1 \mathrm{H}, 8-\mathrm{CH}_{\text {purine-B }}\right), 8.54(\mathrm{~s}$, $\left.0.6 \mathrm{H}, 8-\mathrm{CH}_{\text {purine-A }}\right), 8.20\left(\mathrm{~s}, 1 \mathrm{H}, 2-\mathrm{CH}_{\text {purine-B}}\right), 8.18\left(\mathrm{~s}, 0.6 \mathrm{H}, 2-\mathrm{CH}_{\text {purine-A }}\right), 7.88\left(\mathrm{~s}, 1 \mathrm{H}, 2-\mathrm{CH}_{\text {phenyl-B}}\right)$, $7.85\left(\mathrm{~d}, J=7.6 \mathrm{~Hz}, 1 \mathrm{H}, 6-\mathrm{CH}_{\text {phenyl-B}}\right), 7.76\left(\mathrm{~s}, 0.6 \mathrm{H}, 2-\mathrm{CH}_{\text {phenyl-A) }}\right) 7.74(\mathrm{~d}, J=8.7 \mathrm{~Hz}, 0.6 \mathrm{H}$, 6- $\mathrm{CH}_{\text {phenyl-A) }} 7.46\left(\mathrm{~d}, J=7.3 \mathrm{~Hz}, 1 \mathrm{H}, 4-\mathrm{CH}_{\text {phenyl-B) }}, 7.41\left(\mathrm{~d}, J=6.4 \mathrm{~Hz}, 0.6 \mathrm{H}, 4-\mathrm{CH}_{\text {phenyl-A) }}\right), 7.37\right.$ (t, $\left.J=7.7 \mathrm{~Hz}, 1 \mathrm{H}, 5-\mathrm{CH}_{\text {phenyl-B)}}\right), 7.31\left(\mathrm{t}, J=7.6 \mathrm{~Hz}, 0.6 \mathrm{H}, 5-\mathrm{CH}_{\text {phenyl-A) }}, 6.43\left(\mathrm{~d}, J=4.4 \mathrm{~Hz}, 0.6 \mathrm{H}, 1^{\prime}-\right.\right.$ $\left.\mathrm{CH}_{\mathrm{A}}\right), 6.28\left(\mathrm{~d}, J=7.6 \mathrm{~Hz}, 1 \mathrm{H}, 1^{\prime}-\mathrm{CH}_{\mathrm{B}}\right), 5.78-5.74\left(\mathrm{~m}, 1.6 \mathrm{H}, 2^{\prime}-\mathrm{CH}_{\mathrm{A}}, 3^{\prime}-\mathrm{CH}_{\mathrm{B}}\right), 5.15(\mathrm{dd}, J=7.6$, $\left.5.3 \mathrm{~Hz}, 1 \mathrm{H}, 2^{\prime}-\mathrm{CH}_{\mathrm{B}}\right), 4.93\left(\mathrm{t}, J=5.5 \mathrm{~Hz}, 0.6 \mathrm{H}, 3^{\prime}-\mathrm{CH}_{\mathrm{A}}\right), 4.71-4.67\left(\mathrm{~m}, 1 \mathrm{H}, 4^{\prime}-\mathrm{CH}_{\mathrm{B}}\right), 4.52(\mathrm{dq}, J=5.5$, $2.8 \mathrm{~Hz}, 0.6 \mathrm{H}, 4 '-\mathrm{CH}_{\mathrm{A}}$ ), 4.40 (ddd, $J=13.9,5.2,2.5 \mathrm{~Hz}, 1 \mathrm{H}, 5 '-\mathrm{CH}_{2 \mathrm{~B}}$ ), 4.33 (ddd, J=11.5, 4.7, $2.8 \mathrm{~Hz}, 0.6 \mathrm{H}, 5$ '- $\mathrm{CH}_{2 \mathrm{~A}}$ ), $3.17\left(\mathrm{q}, J=7.3 \mathrm{~Hz}, 30.6 \mathrm{H}, \mathrm{CH}_{2 \mathrm{NEt} 3}\right), 3.38$ (s, $2 \mathrm{H}, \mathrm{CH}_{3 \mathrm{~B}}$ ), $2.31(\mathrm{~s}, 1.8 \mathrm{H}$, 
$\mathrm{CH}_{3 \mathrm{~A}}$ ), 1.26 (t, $\left.J=7.3 \mathrm{~Hz}, 45.8 \mathrm{H}, \mathrm{CH}_{3 \mathrm{NEt} 3}\right) .{ }^{13} \mathrm{C} \mathrm{NMR}\left(\mathrm{D}_{2} \mathrm{O}, 151 \mathrm{MHz}\right): \delta(\mathrm{ppm})=167.5(1 \mathrm{C}$, $\left.\mathrm{C}=\mathrm{O}_{\mathrm{B}}\right), 167.1\left(0.6 \mathrm{C}, \mathrm{C}=\mathrm{O}_{\mathrm{A}}\right), 154.74\left(0.6 \mathrm{C}, \mathrm{C}-6_{\text {purine-A}}\right), 154.71$ (1C, C-6 $\left.6_{\text {purine-B}}\right), 151.9$ (1C, C-2 $\left.2_{\text {purine-B }}\right), 151.8$ (0.6C, C-2 purine-A $\left._{\text {A }}\right), 149.2$ (1C, C-4 purine-B $), 148.5$ (0.6C, C-4 purine-A), 140.2 (0.6C,

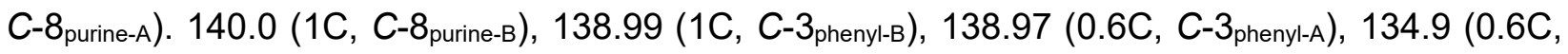

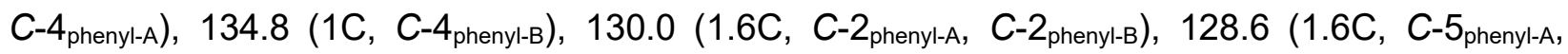

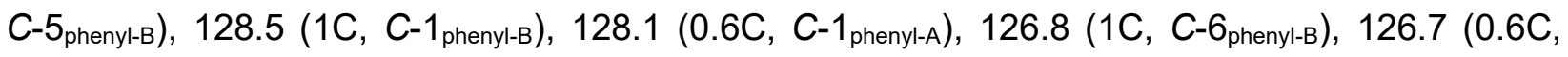
$\left.C-6_{\text {phenyl-A }}\right), 118.4$ (0.6C, C-5 purine-A), 118.3 (1C, C-5 purine-B), 86.0 (1C, C-1'B), $85.9\left(0.6 \mathrm{C}, C-1{ }^{\prime} \mathrm{A}\right), 83.7$ $\left(\mathrm{d}, J=8.8 \mathrm{~Hz}, 0.6 \mathrm{C}, C-4_{\mathrm{A}}^{\prime}\right), 82.5\left(\mathrm{~d}, J=9.2 \mathrm{~Hz}, 1 \mathrm{C}, C-4_{\mathrm{B}}^{\prime}\right), 76.7\left(0.6 \mathrm{C}, C-2_{\mathrm{A}}{ }_{\mathrm{A}}\right), 74.6\left(1 \mathrm{C}, \mathrm{C}-3_{\mathrm{B}}^{\prime}\right)$, $73.3\left(1 \mathrm{C}, C-2^{\prime}{ }_{B}\right), 68.7\left(0.6 \mathrm{C}, C-3_{A}^{\prime}\right), 65.7\left(\mathrm{~d}, J=5.3 \mathrm{~Hz}, 1 \mathrm{C}, C-5_{\mathrm{B}}^{\prime}\right), 64.8(\mathrm{~d}, J=5.3 \mathrm{~Hz}, 0.6 \mathrm{C}, C-$ 5'A), 46.7 (15.3C, $\mathrm{CH}_{2 \mathrm{NEt}}$ ), 20.44 (1C, $\left.\mathrm{CH}_{3 \mathrm{~B}}\right), 20.38\left(0.6 \mathrm{C}, \mathrm{CH}_{3 \mathrm{~A}}\right), 8.3\left(15.3 \mathrm{C}, \mathrm{CH}_{3 \mathrm{NEt}}\right) .{ }^{31} \mathrm{P} \mathrm{NMR}$ $\left(162 \mathrm{MHz}, \mathrm{D}_{2} \mathrm{O} / \mathrm{D}_{3} \mathrm{PO}_{4}\right): \delta(\mathrm{ppm})=-10.8\left(0.6 \mathrm{P}, \beta-\mathrm{P}_{\mathrm{A}}\right),-10.9\left(1 \mathrm{P}, \beta-\mathrm{P}_{\mathrm{B}}\right),-11.5\left(0.6 \mathrm{P}, \alpha-\mathrm{P}_{\mathrm{A}}\right),-11.6$ $\left(1 \mathrm{P}, \alpha-\mathrm{P}_{\mathrm{B}}\right),-23.2\left(\mathrm{t}, J=19.9 \mathrm{~Hz}, 1.6 \mathrm{P}, \mathrm{\gamma}-\mathrm{P}_{\mathrm{A} . \mathrm{B}}\right)$.

2'-O-(2-lodobenzoyl)-adenosine 5'-(tetrahydrogene triphosphate) and 3'-O-(2-lodobenzoyl)adenosine 5'-(tetrahydrogene triphosphate) (14)

The mixture of the products was obtained as colorless solid after lyophilization (2.94 eq. Et $3 \mathrm{~N}$-salt [1033.81 g/mol], 0.7:1 [A:B], $38.5 \mathrm{mg}, 37 \mu \mathrm{mol}, 3.7 \%$ ). $R_{t}$ (Sephadex-D): $14.1 \mathrm{~min} . R_{t}$ (RP-HPLCA): 31.7 min. Purity (HPLC-A): $98 \%\left(R_{t}=13.3 \mathrm{~min}\right)$. LC-MS: $\mathrm{m} / \mathrm{z}=$ calcd. for $\mathrm{C}_{17} \mathrm{H}_{18} \mathrm{IN}_{5} \mathrm{O}_{14} \mathrm{P}_{3}$ 736.0, found $736.0[\mathrm{M}-\mathrm{H}]^{-}\left(R_{t}=5.61 \mathrm{~min}\right)$. Exact mass $(\mathrm{ESI}): \mathrm{m} / \mathrm{z}=$ calcd. for $\mathrm{C}_{17} \mathrm{H}_{18} \mathrm{IN}_{5} \mathrm{O}_{14} \mathrm{P}_{3}$ 735.9113, found $735.9091[\mathrm{M}-\mathrm{H}]^{-} .{ }^{1} \mathrm{H}$ NMR $\left(\mathrm{D}_{2} \mathrm{O}, 400 \mathrm{MHz}\right): \delta(\mathrm{ppm})=8.62\left(\mathrm{~s}, 1.7 \mathrm{H}, 8-\mathrm{CH}_{\text {purine-A, }}\right.$ 8- $\left.\mathrm{CH}_{\text {purine-B) }}\right), 8.21$ (s, 1.7H, 2-CH $\left.\mathrm{C}_{\text {purine-A, }}, 2-\mathrm{CH}_{\text {purine-B}}\right), 7.95\left(\mathrm{~d}, J=8.0 \mathrm{~Hz}, 1 \mathrm{H}, 3-\mathrm{CH}_{\text {phenyl-B) }}\right), 7.90$ (dd, $\left.J=7.8,1.6 \mathrm{~Hz}, 1 \mathrm{H}, 6-\mathrm{CH}_{\text {phenyl-B) }}\right), 7.84\left(\mathrm{~d}, J=8.0 \mathrm{~Hz}, 0.7 \mathrm{H}, 3-\mathrm{CH}_{\text {phenyl-A }}\right), 7.82(\mathrm{dd}, J=7.7,1.7 \mathrm{~Hz}$, $\left.0.7 \mathrm{H}, 6-\mathrm{CH}_{\text {phenyl-A }}\right), 7.45\left(\mathrm{t}, J=7.7 \mathrm{~Hz}, 1 \mathrm{H}, 5-\mathrm{CH}_{\text {phenyl-B}}\right), 7.41\left(\mathrm{t}, J=7.6 \mathrm{~Hz}, 0.7 \mathrm{H}, 5-\mathrm{CH}_{\text {phenyl-A }}\right), 7.22$ (t, $J=7.6 \mathrm{~Hz}, 1 \mathrm{H}, 4-\mathrm{CH}_{\text {phenyl-B) }}, 7.17\left(\mathrm{t}, J=7.7 \mathrm{~Hz}, 0.7 \mathrm{H}, 4-\mathrm{CH}_{\text {phenyl-A) }}, 6.44\left(\mathrm{~d}, J=4.9 \mathrm{~Hz}, 0.7 \mathrm{H}, 1^{\prime}-\right.\right.$ $\left.\mathrm{CH}_{\mathrm{A}}\right), 6.28\left(\mathrm{~d}, J=7.7 \mathrm{~Hz}, 1 \mathrm{H}, 1^{\prime}-\mathrm{CH}_{\mathrm{B}}\right), 5.84\left(\mathrm{t}, J=5.2 \mathrm{~Hz}, 0.7 \mathrm{H}, 2^{\prime}-\mathrm{CH}_{\mathrm{A}}\right), 5.77(\mathrm{~d}, J=5.1 \mathrm{~Hz}, 1 \mathrm{H}$, $\left.3^{\prime}-\mathrm{CH}_{\mathrm{B}}\right), 5.16\left(\mathrm{t}, J=6.4 \mathrm{~Hz}, 1 \mathrm{H}, 2^{\prime}-\mathrm{CH}_{\mathrm{B}}\right), 4.93\left(\mathrm{t}, J=5.2 \mathrm{~Hz}, 0.7 \mathrm{H}, 3^{\prime}-\mathrm{CH}_{\mathrm{A}}\right), 4.74\left(\mathrm{~m}, 1 \mathrm{H}, 4^{\prime}-\mathrm{CH}_{\mathrm{B}}\right)$, $4.52\left(\mathrm{~m}, 0.7 \mathrm{H}, 4^{\prime}-\mathrm{CH}_{\mathrm{A}}\right), 4.40\left(\mathrm{~d}, J=13.1 \mathrm{~Hz}, 2.4 \mathrm{H}, 5^{\prime}-\mathrm{CHH}_{\mathrm{B}}, 5^{\prime}-\mathrm{CH}_{2 \mathrm{~A}}\right), 4.33(\mathrm{~d}, J=11.8 \mathrm{~Hz}, 1 \mathrm{H}$, $5^{\prime}-\mathrm{CHH}_{\mathrm{B}}$ ), 3.17 (q, $\left.J=7.4 \mathrm{~Hz}, 30 \mathrm{H}, \mathrm{CH}_{2} \mathrm{NEt3}\right), 1.26$ (t, $\left.J=7.4 \mathrm{~Hz}, 45 \mathrm{H}, \mathrm{CH}_{3} \mathrm{NEt3}\right) .{ }^{13} \mathrm{C}$ NMR $\left(\mathrm{D}_{2} \mathrm{O}\right.$, $151 \mathrm{MHz}): \delta(\mathrm{ppm})=167.3\left(1 \mathrm{C}, C=\mathrm{O}_{\mathrm{B}}\right), 166.7\left(0.7 \mathrm{C}, C=\mathrm{O}_{\mathrm{A}}\right), 154.9\left(0.7 \mathrm{C}, C-6_{\text {purine-A }}\right), 154.8(1 \mathrm{C}$, C-6 purine-B), 152.2 (1C, C-2 purine-B), 152.0 (0.7C, C-2 purine-A), 149.4 (1C, C-4 purine-B), 148.6 (0.7C,

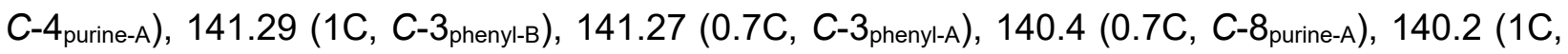
C-8 purine-B $\left._{\text {B }}\right), 133.75$ (0.7C, C-4 $\left.4_{\text {phenyl-A }}\right), 133.69$ (1C, C-4 phenyl-B), 133.5 (1C, C-1 $\left.1_{\text {phenyl-B }}\right), 133.0$ (0.7C, $C-1_{\text {phenyl-A) }}, 131.40$ (1C, C- $\left.6_{\text {phenyl-B }}\right), 131.36$ (0.7C, C- $\left.6_{\text {phenyl-A }}\right), 128.38$ (1C, C-5 $\left.5_{\text {phenyl-B }}\right), 128.37$ (0.7C, $\left.C-5_{\text {phenyl-A }}\right), 118.8$ (1.7C, $C$-5 $\left.5_{\text {purine-A, }} C-5_{\text {purine-B }}\right), 93.61$ (1C, C-2 $\left.2_{\text {phenyl-B }}\right), 93.58$ (0.7C, C-2 $\left.2_{\text {phenyl-A }}\right), 86.1$ (1C, C-1'B), $85.3\left(0.7 \mathrm{C}, C-1_{A}^{\prime}\right), 84.0\left(\mathrm{~d}, J=8.8 \mathrm{~Hz}, 0.7 \mathrm{C}, C-4_{\mathrm{A}}{ }_{\mathrm{A}}\right), 82.3\left(\mathrm{~d}, J=8.7 \mathrm{~Hz}, 1 \mathrm{C}, \mathrm{C}-4_{\mathrm{B}}^{\prime}\right)$, 
$77.2\left(0.7 \mathrm{C}, C-2^{\prime}{ }_{\mathrm{A}}\right), 75.5\left(1 \mathrm{C}, C-3_{\mathrm{B}}^{\prime}\right), 73.2\left(1 \mathrm{C}, C-2_{\mathrm{B}}^{\prime}\right), 68.8\left(0.7 \mathrm{C}, C-3_{\mathrm{A}}{ }_{\mathrm{A}}\right), 65.7\left(1 \mathrm{C}, C-5_{\mathrm{B}}^{\prime}\right), 64.9$ (0.7C, C-5'A), 46.7 (15C, $\left.\mathrm{CH}_{2 \mathrm{NEt} 3}\right), 8.3\left(15 \mathrm{C}, \mathrm{CH}_{3 \mathrm{NEt} 3}\right) .{ }^{31} \mathrm{P} \mathrm{NMR}\left(160 \mathrm{MHz}, \mathrm{D}_{2} \mathrm{O} \mathrm{D}_{3} \mathrm{PO}_{4}\right): \delta(\mathrm{ppm})$ $=-11.4(2 \mathrm{P}, \alpha-\mathrm{P}$, and $\beta-\mathrm{P}),-23.1(1 \mathrm{P}, \mathrm{\gamma}-\mathrm{P})$.

2'-O-(2-Chlorobenzoyl)-adenosine 5'-(tetrahydrogene triphosphate) and 3'-O-(2-Chlorobenzoyl)adenosine 5'-(tetrahydrogene triphosphate) (15)

The mixture of the products was obtained as colorless solid after lyophilization (2.9 eq. Et ${ }_{3} \mathrm{~N}$-salt [939.18 g/mol], 0.6:1 [A:B], $73 \mathrm{mg}, 77.7 \mu \mathrm{mol}, 7.8 \%$ ). $R_{t}$ (Sephadex-B): $11.8 \mathrm{~min} . R_{t}$ (RP-HPLCA): 24.9 min. Purity (HPLC-A): $97 \%\left(R_{t}=12.9 \mathrm{~min}\right.$ [92\%] and $14.4 \mathrm{~min}$ [5 \%]). LC-MS: $\mathrm{m} / \mathrm{z}=$ calcd. for $\mathrm{C}_{17} \mathrm{H}_{18}{ }^{35} \mathrm{CIN}_{5} \mathrm{O}_{14} \mathrm{P}_{3} 644.0$, found $644.0[\mathrm{M}-\mathrm{H}]^{-}\left(R_{t}=5.71 \mathrm{~min}\right)$. Exact mass $(\mathrm{ESI}): \mathrm{m} / \mathrm{z}=$ calcd. for $\mathrm{C}_{17} \mathrm{H}_{18}{ }^{35} \mathrm{CIN}_{5} \mathrm{O}_{14} \mathrm{P}_{3}$ 643.9757, found 643.9759 [M-H] ${ }^{-}{ }^{1} \mathrm{H}$ NMR $\left(\mathrm{D}_{2} \mathrm{O}, 400 \mathrm{MHz}\right): \delta(p p m)$

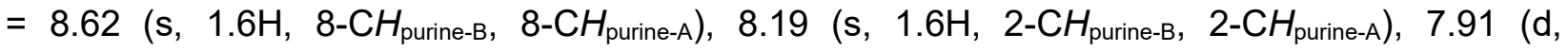
$\left.J=7.6 \mathrm{~Hz}, 1 \mathrm{H}, 2-\mathrm{CH}_{\text {phenyl-B}}\right), 7.83\left(\mathrm{~d}, J=7.7 \mathrm{~Hz}, 0.6 \mathrm{H}, 2-\mathrm{CH}_{\text {phenyl-A }}\right), 7.54-7.41\left(\mathrm{~m}, 2.6 \mathrm{H}, 3-\mathrm{CH}_{\text {phenyl- }}\right.$

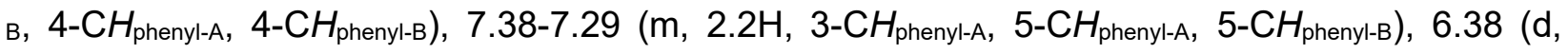
$\left.J=4.2 \mathrm{~Hz}, 0.6 \mathrm{H}, 1^{\prime}-\mathrm{CH}_{\mathrm{A}}\right), 6.21\left(\mathrm{~d}, J=7.3 \mathrm{~Hz}, 1 \mathrm{H}, 1^{\prime}-\mathrm{CH}_{\mathrm{B}}\right), 5.79-5.71\left(\mathrm{~m}, 1.6 \mathrm{H}, 2^{\prime}-\mathrm{CH}_{\mathrm{A}}, 3^{\prime}-\mathrm{CH}_{\mathrm{B}}\right)$, $5.13\left(\mathrm{t}, J=6.5 \mathrm{~Hz}, 1 \mathrm{H}, 2^{\prime}-\mathrm{CH}_{\mathrm{B}}\right), 4.92\left(\mathrm{t}, J=5.3 \mathrm{~Hz}, 0.6 \mathrm{H}, 3^{\prime}-\mathrm{CH}_{\mathrm{A}}\right), 4.70-4.64\left(\mathrm{~m}, 1 \mathrm{H}, 4^{\prime}-\mathrm{CH}_{\mathrm{B}}\right), 4.53-$ $4.46\left(\mathrm{~m}, 0.6 \mathrm{H}, 4{ }^{\prime}-\mathrm{CH}_{\mathrm{A}}\right), 4.45-4.29\left(\mathrm{~m}, 3.2 \mathrm{H}, 5 '-\mathrm{CH}_{2 \mathrm{~B}}, 5\right.$ '- $\left.\mathrm{CH}_{2 \mathrm{~A}}\right), 3.17$ (q, J = 7.2 Hz, 27.6H, $\mathrm{CH}_{2}$ $\mathrm{NEt} 3), 1.26\left(\mathrm{t}, J=7.3 \mathrm{~Hz}, 41.4 \mathrm{H}, \mathrm{CH}_{3 \mathrm{NEt} 3}\right) .{ }^{13} \mathrm{C} \mathrm{NMR}\left(\mathrm{D}_{2} \mathrm{O}, 151 \mathrm{MHz}\right): \delta(\mathrm{ppm})=166.1\left(1 \mathrm{C}, C=\mathrm{O}_{B}\right)$, 165.5 (0.6C, $\left.C=\mathrm{O}_{\mathrm{A}}\right), 154.1$ (0.6C, C-6 purine-A $_{\text {A }}, 153.8$ (1C, C-6 $\left.6_{\text {purine-B }}\right), 151.2$ (0.6C, C-2 purine-A $\left._{\text {A }}\right), 151.0$

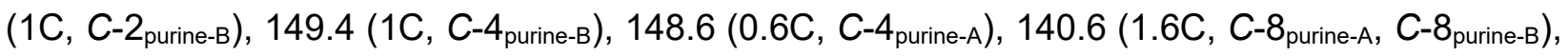

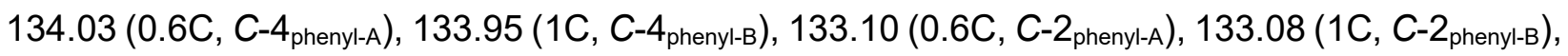

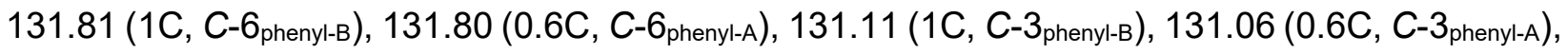

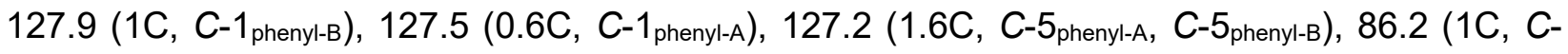
1'B), $85.8\left(0.6 \mathrm{C}, C-1{ }^{A}\right), 83.8\left(\mathrm{~d}, J=8.6 \mathrm{~Hz}, 0.6 \mathrm{C}, C-4{ }_{\mathrm{A}}\right), 83.7\left(\mathrm{~d}, J=8.2 \mathrm{~Hz}, 1 \mathrm{C}, \mathrm{C}-4_{\mathrm{B}}{ }^{\prime}\right), 77.2(0.6 \mathrm{C}$, $\left.C-2_{\mathrm{A}}^{\prime}\right), 75.2\left(1 \mathrm{C}, C-3_{\mathrm{B}}^{\prime}\right), 73.4\left(1 \mathrm{C}, \mathrm{C}-2_{\mathrm{B}}^{\prime}\right), 68.6\left(0.6 \mathrm{C}, \mathrm{C}-3_{\mathrm{A}}^{\prime}\right), 65.7\left(1 \mathrm{C}, \mathrm{C}-5_{\mathrm{B}}^{\prime}\right), 64.8\left(0.6 \mathrm{C}, C-5_{\mathrm{A}}^{\prime}\right)$, 46.7 (13.8C, $\left.\mathrm{CH}_{2 \mathrm{NEt} 3}\right), 8.3\left(13.8 \mathrm{C}, \mathrm{CH}_{3 \mathrm{NEt} 3}\right)$. $C-5_{\text {purine-A }}$ and $C-5_{\text {purine-B }}$ could not be seen. ${ }^{31} \mathrm{P}$ NMR $\left(160 \mathrm{MHz}, \mathrm{D}_{2} \mathrm{O} / \mathrm{D}_{3} \mathrm{PO}_{4}\right): \delta(\mathrm{ppm})=-10.3(1 \mathrm{P}, \beta-\mathrm{P}),-11.4(1 \mathrm{P}, \alpha-\mathrm{P}),-22.3(1 \mathrm{P}, \mathrm{y}-\mathrm{P})$.

2'-O-(2,3-Dichlorobenzoyl)-adenosine 5'-(tetrahydrogene triphosphate) and 3'-O-(2,3-

Dichlorobenzoyl)-adenosine 5'-(tetrahydrogene triphosphate) (16)

The mixture of the products was obtained as colorless solid after lyophilization ( $0.59 \mathrm{eq}$. $\mathrm{Et}_{3} \mathrm{~N}$-salt [740.14 g/mol], 0.5:1 [A:B], $4 \mathrm{mg}, 5.4 \mu \mathrm{mol}, 0.5 \%$ ). $R_{t}$ (Sephadex-B): $14.9 \mathrm{~min} . R_{t}$ (RP-HPLC-A): $32.9 \mathrm{~min}$ and $33.5 \mathrm{~min}$. Purity (HPLC-A): $>99 \%\left(R_{t}=12.9 \mathrm{~min}\right)$. LC-MS: $\mathrm{m} / \mathrm{z}=$ calcd. for $\mathrm{C}_{17} \mathrm{H}_{17}{ }^{35} \mathrm{Cl}_{2} \mathrm{~N}_{5} \mathrm{O}_{14} \mathrm{P}_{3} 678.0$, found $678.0[\mathrm{M}-\mathrm{H}]^{-}\left(R_{t}=5.81 \mathrm{~min}\right)$. Exact mass $(\mathrm{ESI}): \mathrm{m} / \mathrm{z}=$ calcd. for $\mathrm{C}_{17} \mathrm{H}_{17}{ }^{35} \mathrm{Cl}_{2} \mathrm{~N}_{5} \mathrm{O}_{14} \mathrm{P}_{3} 677.9367$, found $677.9366[\mathrm{M}-\mathrm{H}]^{-} .{ }^{1} \mathrm{H}$ NMR $\left(\mathrm{D}_{2} \mathrm{O}, 600 \mathrm{MHz}\right): \delta(\mathrm{ppm})=8.70$ (s, $\left.1 \mathrm{H}, 8-\mathrm{CH}_{\text {purine-B}}\right), 8.68\left(\mathrm{~s}, 0.5 \mathrm{H}, 8-\mathrm{CH}_{\text {purine-A }}\right), 8.42\left(\mathrm{~s}, 1.5 \mathrm{H}, 2-\mathrm{CH}_{\text {purine-A }}, 2-\mathrm{CH}_{\text {purine-B }}\right), 7.88$ (d, 
$J=7.8 \mathrm{~Hz}, 1 \mathrm{H}, 6-\mathrm{CH}_{\text {phenyl-B) }}, 7.83\left(\mathrm{dd}, J=7.9,1.6 \mathrm{~Hz}, 0.5 \mathrm{H}, 6-\mathrm{CH}_{\text {phenyl-A }}\right), 7.76(\mathrm{~d}, J=8.0 \mathrm{~Hz}, 1 \mathrm{H}$, 4- $\left.\mathrm{CH}_{\text {phenyl-A) }}\right) 7.74\left(\mathrm{~d}, J=8.2 \mathrm{~Hz}, 0.5 \mathrm{H}, 4-\mathrm{CH}_{\text {phenyl-A) }}\right), 7.41$ (t, $\left.J=7.9 \mathrm{~Hz}, 1 \mathrm{H}, 5-\mathrm{CH}_{\text {phenyl-B) }}\right), 3.39$ (t, $\left.J=8.0 \mathrm{~Hz}, 0.5 \mathrm{H}, 5-\mathrm{CH}_{\text {phenyl-A) }}\right), 6.48\left(\mathrm{~d}, J=3.8 \mathrm{~Hz}, 0.5 \mathrm{H}, 1^{\prime}-\mathrm{CH}_{\mathrm{A}}\right), 6.27\left(\mathrm{~d}, J=7.2 \mathrm{~Hz}, 1 \mathrm{H}, 1^{\prime}-\mathrm{CH}_{\mathrm{B}}\right)$, $5.87\left(\mathrm{t}, J=4.5 \mathrm{~Hz}, 0.5 \mathrm{H}, 2^{\prime}-\mathrm{CH}_{\mathrm{A}}\right), 5.79\left(\mathrm{~d}, J=4.5 \mathrm{~Hz}, 1 \mathrm{H}, 3^{\prime}-\mathrm{CH}_{\mathrm{B}}\right), 5.16\left(\mathrm{t}, J=6.1 \mathrm{~Hz}, 1 \mathrm{H}, 2^{\prime}-\mathrm{CH}_{\mathrm{B}}\right)$, $4.96\left(\mathrm{t}, J=5.5 \mathrm{~Hz}, 0.5 \mathrm{H}, 3{ }^{\prime}-\mathrm{CH}_{\mathrm{A}}\right), 4.77\left(\mathrm{~m}, 1 \mathrm{H}, 4{ }^{\prime}-\mathrm{CH}_{\mathrm{B}}\right), 4.48\left(\mathrm{~m}, 0.4 \mathrm{H}, 4{ }^{\prime}-\mathrm{CH}_{\mathrm{A}}\right), 4.41$ (d, $\left.J=11.7 \mathrm{~Hz}, 0.5 \mathrm{H}, 5^{\prime}-\mathrm{CHH}_{\mathrm{A}}\right), 4.38-4.31\left(\mathrm{~m}, 2.5 \mathrm{H}, 5^{\prime}-\mathrm{CH} H_{\mathrm{A}}, 5^{\prime}-\mathrm{CH}_{2 \mathrm{~B}}\right), 3.18\left(\mathrm{q}, J=7.3 \mathrm{~Hz}, 8 \mathrm{H}, \mathrm{CH}_{2}\right.$ $\mathrm{NEt} 3), 1.26\left(\mathrm{t}, J=7.4 \mathrm{~Hz}, 12 \mathrm{H}, \mathrm{CH}_{3} \mathrm{NEt} 3\right) .{ }^{13} \mathrm{C} \mathrm{NMR}\left(\mathrm{D}_{2} \mathrm{O}, 151 \mathrm{MHz}\right): \delta(p p m)=166.0\left(1 \mathrm{C}, C=\mathrm{O}_{B}\right)$, $165.5\left(0.5 \mathrm{C}, C=\mathrm{O}_{\mathrm{A}}\right), 150.2$ (1C,C-6 purine-B$\left._{\text {B }}\right), 150.1$ (0.5C, C-6 $\left.6_{\text {purine-A }}\right), 148.8$ (1.5C, C- $4_{\text {purine-A, }}$

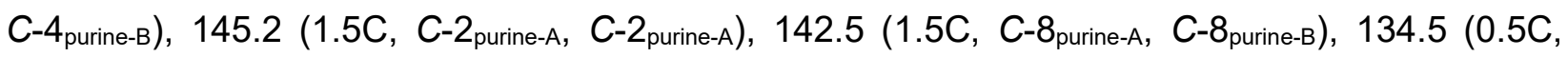
C-4 phenyl-A), 134.3 (1C, C-4 phenyl-B), 134.14 (0.5C, C-1 phenyl-A), 134.10 (1C, C-1 phenyl-B), 131.0 (0.5C,

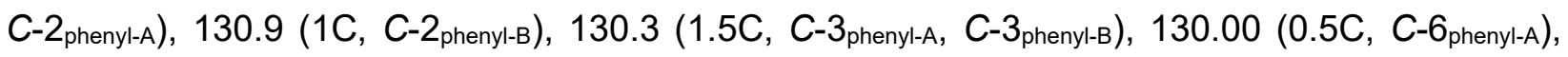
129.95 (1C, C-6 phenyl-B $\left._{1}\right), 128.0$ (1.5C, C-5 $\left.5_{\text {phenyl-A, }} C-5_{\text {phenyl-B }}\right), 107.5$ (1.5C, C-5 $\left.5_{\text {purine-A, }} C-5_{\text {purine-B }}\right), 87.1$ (1C, C-1'B), $86.7\left(0.5 \mathrm{C}, C-1_{\mathrm{A}}^{\prime}\right), 83.9\left(\mathrm{~d}, J=7.0 \mathrm{~Hz}, 0.5 \mathrm{C}, C-4_{\mathrm{A}}^{\prime}\right), 82.7\left(\mathrm{~d}, J=8.7 \mathrm{~Hz}, 1 \mathrm{C}, C-4_{\mathrm{B}}^{\prime}\right)$, $77.6\left(0.5 \mathrm{C}, C-2^{\prime} \mathrm{A}\right), 75.5\left(1 \mathrm{C}, C-3_{\mathrm{B}}^{\prime}\right), 73.5\left(1 \mathrm{C}, C-2_{\mathrm{B}}^{\prime}\right), 68.5\left(0.5 \mathrm{C}, C-3_{\mathrm{A}}^{\prime}\right), 65.6\left(1 \mathrm{C}, C-5_{\mathrm{B}}{ }_{\mathrm{B}}\right), 64.5$ (0.5C, C-5'A), 46.8 (4C, $\left.\mathrm{CH}_{2 \mathrm{NEt} 3}\right), 8.3\left(4 \mathrm{C}, \mathrm{CH}_{3} \mathrm{NEt}_{3}\right) .{ }^{31} \mathrm{P}$ NMR $\left(162 \mathrm{MHz}, \mathrm{D}_{2} \mathrm{O} / \mathrm{D}_{3} \mathrm{PO}_{4}\right): \delta(\mathrm{ppm})=$ 10.9 (2P, $\alpha-\mathrm{P}, \beta-\mathrm{P}) . \gamma$-P could not be seen.

2'-O-[2-Chloro-3-(trifluoromethyl)benzoyl]-adenosine 5'-(tetrahydrogene triphosphate) and 3'-O[2-Chloro-3-(trifluoromethyl)benzoyl]-adenosine 5'-(tetrahydrogene triphosphate) (17)

The compound was purified by semi preparative RP-HPLC on a Polaris C18 column. (TEAA buffer/ACN; 5mL/min; 0 min 90/10; 0-30 min 70/30; 30-40 min 70/30; 41-55 min 90/10; 56-65 min 90/10; product: $R_{t}=45 \mathrm{~min}$ ). The pooled fractions were directly cooled to $-80^{\circ} \mathrm{C}$ and lyophilized to obtain the final product as a glassy solid in a yield of $10 \%\left(185 \mathrm{mg}, 0.19 \mathrm{mmol}, 2.7 \mathrm{eq}\right.$. NEt N- $^{-}$ salt). $R_{t}$ (RP-HPLC-A): $45 \mathrm{~min}$. Purity (HPLC-B): $97 \%\left(R_{t}=13.9 \mathrm{~min}\right)$ LC-MS: $\mathrm{m} / \mathrm{z}=$ calcd. for for $\mathrm{C}_{18} \mathrm{H}_{17}{ }^{35} \mathrm{CIF}_{3} \mathrm{~N}_{5} \mathrm{O}_{14} \mathrm{P}_{3} 712.0$, found $712.0[\mathrm{M}-\mathrm{H}]^{-}\left(R_{t}=5.73 \mathrm{~min}\right)$. Exact mass $(\mathrm{ESI}): \mathrm{m} / \mathrm{z}=$ calcd. for $\mathrm{C}_{18} \mathrm{H}_{17}{ }^{35} \mathrm{CIF}_{3} \mathrm{~N}_{5} \mathrm{O}_{14} \mathrm{P}_{3} 711.9631$, found $711.9598[\mathrm{M}-\mathrm{H}]^{-} .{ }^{1} \mathrm{H}$ NMR $\left(\mathrm{D}_{2} \mathrm{O}, 400 \mathrm{MHz}\right): \delta(\mathrm{ppm})=8.61$ (s, $\left.1 \mathrm{H}, 8-\mathrm{CH}_{\text {purine-B}}\right), 8.59\left(\mathrm{~s}, 0.55 \mathrm{H}, 8-\mathrm{CH}_{\text {purine-A }}\right), 8.59\left(\mathrm{~s}, 0.16 \mathrm{H}, 8-\mathrm{CH}_{\text {purine-ATP }}\right), 8.25(\mathrm{~s}, 0.16 \mathrm{H}, 2-$ $\left.\mathrm{CH}_{\text {purine-ATP}}\right), 8.23\left(\mathrm{~s}, 1 \mathrm{H}, 2-\mathrm{CH}_{\text {purine-B }}\right), 8.20\left(\mathrm{~s}, 0.55 \mathrm{H}, 2-\mathrm{CH}_{\text {purine-A }}\right), 8.16(\mathrm{~d}, J=7.9 \mathrm{~Hz}, 1 \mathrm{H}, 6-$

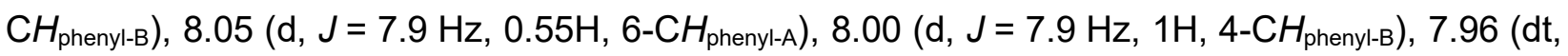
$J=7.9,2.1 \mathrm{~Hz}, 0.55 \mathrm{H}, 4-\mathrm{CH}_{\text {phenyl-A) }}, 7.77$ (dd, $J=7.9,1.6 \mathrm{~Hz}, 0.5 \mathrm{H}, 4-\mathrm{CH}_{\text {phenyl-C) }}, 7.60$ (td, $J=7.9$, $\left.2.3 \mathrm{~Hz}, 1 \mathrm{H}, 5-\mathrm{CH}_{\text {phenyl-B}}\right), 7.56\left(\mathrm{~m}, 1 \mathrm{H}, 5-\mathrm{CH}_{\text {phenyl-A, }} 6-\mathrm{CH}_{\text {phenyl-C}}\right), 7.48\left(\mathrm{t}, \mathrm{J}=7.7 \mathrm{~Hz}, 0.5 \mathrm{H}, 5-\mathrm{CH}_{\text {phenyl- }}\right.$ c), $6.45\left(\mathrm{~d}, J=4.9 \mathrm{~Hz}, 0.55 \mathrm{H}, 1^{\prime}-\mathrm{CH}_{\mathrm{A}}\right), 6.24\left(\mathrm{~d}, J=7.7 \mathrm{~Hz}, 1 \mathrm{H}, 1^{\prime}-\mathrm{CH}_{\mathrm{B}}\right), 6.13(\mathrm{~d}, J=6.0 \mathrm{~Hz}, 0.16 \mathrm{H}$, $\left.1^{\prime}-\mathrm{CH}_{\text {ATP }}\right), 5.86\left(\mathrm{t}, J=5.2 \mathrm{~Hz}, 0.55 \mathrm{H}, 2^{\prime}-\mathrm{CH}_{\mathrm{A}}\right), 5.84\left(\mathrm{dd}, J=5.3,1.7 \mathrm{~Hz}, 1 \mathrm{H}, 3^{\prime}-\mathrm{CH}_{\mathrm{B}}\right), 5.17$ (dd, $\left.J=7.7,5.2 \mathrm{~Hz}, 1 \mathrm{H}, 2^{\prime}-\mathrm{CH}_{\mathrm{B}}\right), 4.93\left(\mathrm{t}, J=5.2 \mathrm{~Hz}, 0.55 \mathrm{H}, 3^{\prime}-\mathrm{CH}_{\mathrm{A}}\right), 4.79\left(\mathrm{~m}, 0.16 \mathrm{H}, 2^{\prime}-\mathrm{CH} H_{\text {ATP }}\right), 4.76-$ $4.73\left(\mathrm{~m}, 1 \mathrm{H}, 4^{\prime}-\mathrm{CH}_{\mathrm{B}}\right), 4.58\left(\mathrm{dd}, J=5.1,3.3 \mathrm{~Hz}, 0.16 \mathrm{H}, 3^{\prime}-\mathrm{CH}_{\text {ATP }}\right), 4.49$ (dq, J = 5.0, $2.7 \mathrm{~Hz}, 0.55 \mathrm{H}$, 
4'- $\left.\mathrm{CH}_{\mathrm{A}}\right), 4.41-4.33\left(\mathrm{~m} 3.36 \mathrm{H}, 5\right.$ '- $\left.\mathrm{CH}_{2 \mathrm{~A}}, 5{ }^{\prime}-\mathrm{CHH}_{\mathrm{B}}, 4^{\prime}-\mathrm{CH}_{\text {ATP }}\right), 4.30-4.25\left(\mathrm{~m}, 1.16 \mathrm{H}, 5 '-\mathrm{CH}_{\mathrm{B}}\right.$, 5'-CHH ${ }_{\text {ATP }}$ ), 4.21 (dt, $\left.J=11.8,3.7 \mathrm{~Hz}, 0.16 \mathrm{H}, 5 '-\mathrm{CH} H_{\text {ATP }}\right), 3.18$ (q, $J=7.4 \mathrm{~Hz}, 44.6 \mathrm{H}, \mathrm{CH}_{2}$ NEt3), $1.26\left(\mathrm{t}, J=7.4 \mathrm{~Hz}, 67.0 \mathrm{H}, \mathrm{CH}_{3 \mathrm{NEt} 3}\right) .{ }^{13} \mathrm{C} \operatorname{NMR}\left(\mathrm{D}_{2} \mathrm{O}, 151 \mathrm{MHz}\right): \delta(\mathrm{ppm})=174.8\left(0.5 \mathrm{C}, \mathrm{C}=\mathrm{O}_{\mathrm{C}}\right)$,

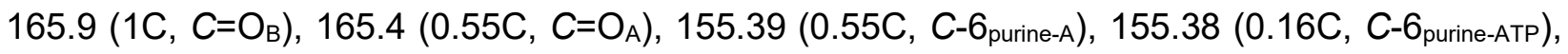
155.33 (1C, C-6 purine-B), 152.56 (1C, C-2 purine-B), 152.53 (0.55C, C-2 $2_{\text {purine-A) }} 152.48$ (0.16C,

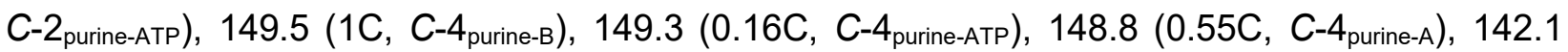

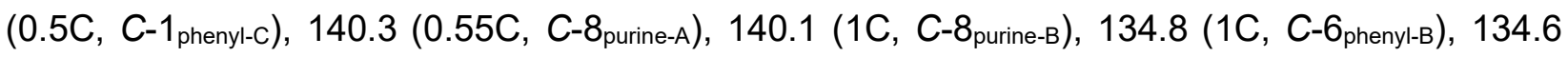

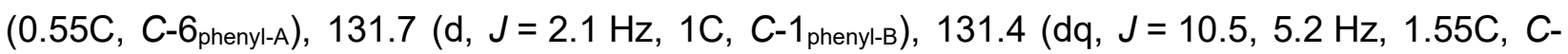

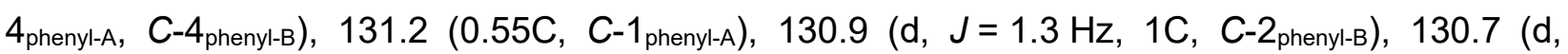

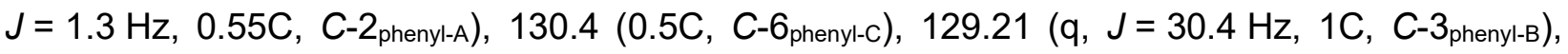

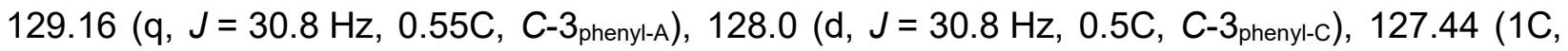
C-5 phenyl-B), 127.40 (0.55C, C-5 phenyl-A), 127.2 (q, J=5.4 Hz, 0.5C,C-4 phenyl-C), 126.3 (0.5C,

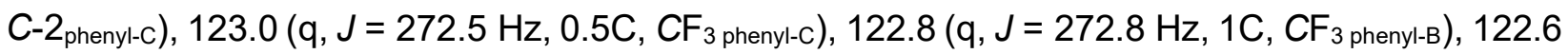
(q, J $\left.=272.8 \mathrm{~Hz}, 0.55 \mathrm{C}, \mathrm{CF}_{3 \text { phenyl-A }}\right), 118.6$ (1.71C, C-5 purine-A, $C-5_{\text {purine-B, }} C-5_{\text {purine-ATP) }}, 86.8$ (0.16C, C-1'AтP), 85.9 (1C, C-1'B), 85.5 (0.55C,C-1'A), 84.2 (d, J = 9.2 Hz, 0.16C, C-4'ATP), 84.0 (d, $\left.J=9.2 \mathrm{~Hz}, 0.55 \mathrm{C}, C-4{ }_{\mathrm{A}}^{\prime}\right), 82.3\left(\mathrm{~d}, J=9.1 \mathrm{~Hz}, 1 \mathrm{C}, C-4{ }_{\mathrm{B}}\right), 77.7\left(0.55 \mathrm{C}, C-2_{\mathrm{A}}{ }^{\mathrm{A}}\right), 75.7\left(1 \mathrm{C}, \mathrm{C}-3_{\mathrm{B}}^{\prime}\right), 74.4$ (0.16C, C-2'ATP), 73.1 (1C,C-2'B), 70.5 (0.16C, C-3'ATP), $68.8\left(0.55 \mathrm{C}, C-3^{\prime}{ }_{\mathrm{A}}\right), 65.7$ (d, J = $5.2 \mathrm{~Hz}$, 1C, C-5'B), 65.4 (d, J = 5.2 Hz, 0.16C, C-5'ATP), 64.9 (d, J = 5.6 Hz, 0.55C, C-5'A), 46.7 (22.33C, $\mathrm{CH}_{2 \mathrm{NEt} 3}$ ), 8.3 (22.33C, $\mathrm{CH}_{3 \mathrm{NEt} 3}$ ). ${ }^{31} \mathrm{P}$ NMR (162 MHz, $\left.\mathrm{D}_{2} \mathrm{O} / \mathrm{D}_{3} \mathrm{PO}_{4}\right): \delta(\mathrm{ppm})=-10.8\left(1.66 \mathrm{P}, \beta-\mathrm{P}_{\mathrm{A}, \mathrm{B}}\right)$, -11.4 (0.66P, $\left.\alpha-\mathrm{P}_{\mathrm{A}}\right),-11.5\left(1 \mathrm{P}, \alpha-\mathrm{P}_{\mathrm{B}}\right),-23.1\left(1.66 \mathrm{P}, \mathrm{y}-\mathrm{P}_{\mathrm{A}, \mathrm{B}}\right) .{ }^{19} \mathrm{~F} \mathrm{NMR}\left(376 \mathrm{MHz}, \mathrm{D}_{2} \mathrm{O}\right): \delta(\mathrm{ppm})=$ $62.18\left(1.5 \mathrm{~F}, \mathrm{CF}_{3-\mathrm{C}}\right),-62.23\left(3 \mathrm{~F}, \mathrm{CF}_{3-\mathrm{B}}\right),-62.3\left(1.65 \mathrm{~F}, \mathrm{C} F_{3-\mathrm{A}}\right)$.

2'-O-(4-Azidobenzoyl)-adenosine 5'-(tetrahydrogene triphosphate) and 3'-O-(4-Azidobenzoyl)adenosine 5'-(tetrahydrogene triphosphate) (18)

The mixture of the products was obtained as orange solid after lyophilization (3.35 eq. $\mathrm{Et}_{3} \mathrm{~N}$ [991.79 g/mol], 0.55:1 [A:B], $24 \mathrm{mg}, 24 \mu \mathrm{mol}, 2.4 \%$ ). $R_{t}$ (Sephadex-D): $11.1 \mathrm{~min} . R_{t}$ (RP-HPLCA): 32.7 min. Purity (HPLC-A): $96 \%\left(R_{t}=13.3 \mathrm{~min}[84 \%\right.$ ] and $14.5 \mathrm{~min}[12 \%])$. LC-MS: $\mathrm{m} / \mathrm{z}=$ calcd. for $\mathrm{C}_{17} \mathrm{H}_{18} \mathrm{~N}_{8} \mathrm{O}_{14} \mathrm{P}_{3} 651.0$, found $651.0[\mathrm{M}-\mathrm{H}]^{-}\left(R_{t}=5.60 \mathrm{~min}\right)$. Exact mass $(\mathrm{ESI}): \mathrm{m} / \mathrm{z}=$ calcd. for $\mathrm{C}_{17} \mathrm{H}_{18} \mathrm{~N}_{8} \mathrm{O}_{14} \mathrm{P}_{3} 651.0161$, found $651.0152[\mathrm{M}-\mathrm{H}]^{-}$. ${ }^{1} \mathrm{H}$ NMR $\left(\mathrm{D}_{2} \mathrm{O}, 400 \mathrm{MHz}\right): \delta(\mathrm{ppm})=8.60(\mathrm{~s}$, $\left.1 \mathrm{H}, 8-\mathrm{CH}_{\text {purine-B }}\right), 8.55\left(\mathrm{~s}, 0.55 \mathrm{H}, 8-\mathrm{CH}_{\text {purine-A }}\right), 8.23\left(\mathrm{~s}, 1 \mathrm{H}, 2-\mathrm{CH}_{\text {purine-B }}\right), 8.18\left(\mathrm{~s}, 0.55 \mathrm{H}, 2-\mathrm{CH}_{\text {purine- }}\right.$ А), 8.13-8.07 (m, 2H, 2,6- $\left.\mathrm{CH}_{\text {phenyl-B}}\right)$, 8.01-7.97 (m, 1.1H, 2,6- $\left.\mathrm{CH}_{\text {phenyl-A }}\right), 7.18-7.12(\mathrm{~m}, 2 \mathrm{H}, 3,5-$ $\left.\mathrm{CH}_{\text {phenyl-B}}\right), 7.12-7.07\left(\mathrm{~m}, 1.1 \mathrm{H}, 3,5-\mathrm{CH}_{\text {phenyl-A) }}, 6.43\right.$ (dd, J = 4.4, $1.8 \mathrm{~Hz}, 0.55 \mathrm{H}, 1$ '- $\left.\mathrm{CH}_{\mathrm{A}}\right), 6.28$ (dd, $\left.J=7.5,2.4 \mathrm{~Hz}, 1 \mathrm{H}, 1^{\prime}-\mathrm{CH}_{\mathrm{B}}\right), 5.80-5.75\left(\mathrm{~m}, 1.55 \mathrm{H}, 2^{\prime}-\mathrm{CH}_{\mathrm{A}}, 3^{\prime}-\mathrm{CH}_{\mathrm{B}}\right), 5.14(\mathrm{td}, J=7.7,5.1 \mathrm{~Hz}, 1 \mathrm{H}$, 2'-CHB $\mathrm{CH}_{\mathrm{B}}, 4.91\left(\mathrm{t}, \mathrm{J}=5.6 \mathrm{~Hz}, 0.55 \mathrm{H}, 3{ }^{\prime}-\mathrm{CH}_{\mathrm{A}}\right), 4.70\left(\mathrm{~m}, 1 \mathrm{H}, 4^{\prime}-\mathrm{CH}_{\mathrm{B}}\right), 4.53-4.49\left(\mathrm{~m}, 0.55 \mathrm{H}, 4{ }^{\prime}-\mathrm{CH}_{\mathrm{A}}\right)$, 4.42-4.34 (m, 2.1H, 5'-CHH $\left.\mathrm{H}_{\mathrm{B}}, 5^{\prime}-\mathrm{CH}_{2 \mathrm{~A}}\right), 4.32-4.28\left(\mathrm{~m}, 1 \mathrm{H}, 5^{\prime}-\mathrm{CHH}_{\mathrm{B}}\right), 3.18(\mathrm{q}, J=7.3 \mathrm{~Hz}, 31.2 \mathrm{H}$, 
$\left.\mathrm{CH}_{2 \mathrm{NEt} 3}\right), 1.26\left(\mathrm{t}, J=7.4 \mathrm{~Hz}, 46.8 \mathrm{H}, \mathrm{CH}_{3} \mathrm{NEt3}\right) .{ }^{13} \mathrm{C} \mathrm{NMR}\left(\mathrm{D}_{2} \mathrm{O}, 151 \mathrm{MHz}\right): \delta(\mathrm{ppm})=166.7(1 \mathrm{C}$, $\left.C=\mathrm{O}_{\mathrm{B}}\right), 166.3$ (0.55C, $\left.C=\mathrm{O}_{\mathrm{A}}\right), 155.0$ (1.55C, C-6 $\left.6_{\text {purine-A }}, C-6_{\text {purine-B}}\right), 152.2$ (1C, C-2 $\left.2_{\text {purine-B}}\right), 152.0$ (0.55C, C-2 purine-A $\left._{\text {A }}\right), 149.4$ (1C, C-4 purine-B $), 148.6$ (0.55C, C-4 $\left.4_{\text {purine-A }}\right), 145.9$ (0.55C, C-4 $\left.4_{\text {phenyl-A }}\right), 145.7$ (1C, C-4 phenyl-B), 140.3 (0.55C, C-8 purine-A $\left._{\text {A }}\right), 140.1$ (1C, C-8 $\left.8_{\text {purine-B }}\right), 131.7$ (2C, C- $\left.2_{\text {phenyl-B, }} C-6_{\text {phenyl-B }}\right)$, 131.6 (1.1C, $C$ - $\left.2_{\text {phenyl-A, }} C-6_{\text {phenyl-A }}\right), 125.0$ (1C, $C$ - $\left.1_{\text {phenyl-B }}\right), 124.5$ (0.55C, $C$ - $\left.1_{\text {phenyl-A }}\right), 119.1$ (3.1C, $\left.C-3_{\text {phenyl-A, }} C-5_{\text {phenyl-A, }} C-3_{\text {phenyl-B, }} C-5_{\text {phenyl-B }}\right), 118.5$ (1.55C, C- $\left.5_{\text {purine-A, }} C-5_{\text {purine-B }}\right), 86.02$ (0.55C, $C$ $\left.1^{\prime} \mathrm{A}\right), 85.99\left(0.55 \mathrm{C}, C-1_{B}{ }_{B}\right), 83.6\left(\mathrm{~d}, J=9.3 \mathrm{~Hz}, 0.55 \mathrm{C}, C-4_{\mathrm{A}}{ }_{\mathrm{A}}\right), 82.5$ (d, J = 9.3 Hz, 1C, C-4'B), 76.8 (0.55C, C-2'A), $74.6\left(C-3_{B}^{\prime}\right), 73.2\left(1 C, C-2_{B}^{\prime}\right), 68.7\left(0.55 C, C-3_{A}^{\prime}\right), 65.7\left(d, J=5.3 \mathrm{~Hz}, 1 C, C-5_{B}^{\prime}\right)$, $64.7\left(\mathrm{~d}, J=5.1 \mathrm{~Hz}, 0.55 \mathrm{C}, \mathrm{C}-5^{\prime} \mathrm{A}\right), 46.7\left(15.6 \mathrm{C}, \mathrm{CH}_{2 \mathrm{NEt3}}\right), 8.3\left(15.6 \mathrm{C}, \mathrm{CH}_{3 \mathrm{NEt3}}\right) .{ }^{31} \mathrm{P} \mathrm{NMR}(162 \mathrm{MHz}$, $\left.\mathrm{D}_{2} \mathrm{O} / \mathrm{D}_{3} \mathrm{PO}_{4}\right): \delta(\mathrm{ppm})=-10.8,-11.4$ and $-11.5(2 \mathrm{P}, \alpha-\mathrm{P}$ and $\beta-\mathrm{P}),-23.2(1 \mathrm{P}, \gamma-\mathrm{P})$.

2'-O-(4-Nitrobenzoyl)-adenosine 5'-(tetrahydrogene triphosphate) and 3'-O-(4-Nitrobenzoyl)adenosine 5'-(tetrahydrogene triphosphate) (19)

The mixture of the products was obtained as colorless solid after lyophilization ( $2.5 \mathrm{eq}$. Et ${ }_{3} \mathrm{~N}$-salt and 0.12 eq. ATP and 0.17 eq. 4-nitrobenzoic acid $\{C$ C [998.54 g/mol], 0.5:1 [A:B], $1 \mathrm{mg}, 1 \mu \mathrm{mol}$, $0.1 \%$ ). $R_{t}$ (Sephadex-D): 14.1 min. $R_{t}$ (RP-HPLC-C): 30.6 min. Purity (HPLC-A): $90 \%\left(R_{t}=12.0\right.$ min) \{impurities are ATP $\left(R_{t}=11.1 \mathrm{~min}[3.5 \%]\right)$ and 4-nitrobenzoic acid $\left.\left(R_{t}=10.9 \mathrm{~min}[6.5 \%]\right)\right\}$. LC-MS: $\mathrm{m} / \mathrm{z}=$ calcd. for $\mathrm{C}_{17} \mathrm{H}_{19} \mathrm{~N}_{6} \mathrm{O}_{16} \mathrm{P}_{3} 655.0$, found $655.0[\mathrm{M}-\mathrm{H}]^{-}\left(R_{t}=5.71 \mathrm{~min}\right)$. Exact mass (ESI): $\mathrm{m} / \mathrm{z}=$ calcd. for $\mathrm{C}_{17} \mathrm{H}_{19} \mathrm{~N}_{6} \mathrm{O}_{16} \mathrm{P}_{3} 654.9998$, found 655.0019 [M-H]- . ${ }^{1} \mathrm{H}$ NMR $\left(\mathrm{D}_{2} \mathrm{O}, 600 \mathrm{MHz}\right)$ : $\delta(\mathrm{ppm})=8.61\left(\mathrm{~s}, 1 \mathrm{H}, 8-\mathrm{CH}_{\text {purine-B}}\right), 8.56\left(\mathrm{~s}, 0.5 \mathrm{H}, 8-\mathrm{CH}_{\text {purine-A }}\right), 8.52\left(\mathrm{~s}, 0.12 \mathrm{H}, 8-\mathrm{CH}_{\text {purine-ATP }}\right), 8.41-$ $8.38\left(\mathrm{~m}, 1 \mathrm{H}, 2,6-\mathrm{CH}_{\text {phenyl- } \mathrm{B}}\right), 8.38-8.33\left(\mathrm{~m}, 3 \mathrm{H}, 2,6-\mathrm{CH}_{\text {phenyl-A, }} 3,5-\mathrm{CH}_{\text {phenyl-B }}\right), 8.28-8.27(\mathrm{~m}, 0.34 \mathrm{H}$, 3,5- $\left.\mathrm{CH}_{\text {phenyl-C}}\right), 8.27$ (s, $\left.1 \mathrm{H}, 2-\mathrm{CH}_{\text {purine-B}}\right), 8.26-8.24\left(\mathrm{~m}, 1.12 \mathrm{H}, 3,5-\mathrm{CH}_{\text {phenyl-A, }} 2-\mathrm{CH}_{\text {purine-ATP) }}\right), 8.18$ (s, $\left.0.5 \mathrm{H}, 2-\mathrm{CH}_{\text {purine-A }}\right), 7.99-7.97\left(\mathrm{~m}, 0.34 \mathrm{H}, 2,6-\mathrm{CH}_{\text {phenyl-C) }}\right) 6.49\left(\mathrm{~d}, J=4.1 \mathrm{~Hz}, 0.5 \mathrm{H}, 1^{\prime}-\mathrm{CH}_{\mathrm{A}}\right), 6.33(\mathrm{~d}$, $\left.J=7.6 \mathrm{~Hz}, 1 \mathrm{H}, 1^{\prime}-\mathrm{CH}_{\mathrm{B}}\right), 6.13\left(\mathrm{~d}, J=6.0 \mathrm{~Hz}, 0.12 \mathrm{H}, 1^{\prime}-\mathrm{CH}_{\mathrm{ATP}}\right), 5.87-5.82\left(\mathrm{~m}, 1.5 \mathrm{H}, 2^{\prime}-\mathrm{CH}_{\mathrm{A}}, 3^{\prime}-\mathrm{CH}_{\mathrm{B}}\right)$, $5.17\left(\mathrm{dd}, J=7.5,5.2 \mathrm{~Hz}, 1 \mathrm{H}, 2^{\prime}-\mathrm{CH}_{\mathrm{B}}\right), 4.95\left(\mathrm{t}, J=5.6 \mathrm{~Hz}, 0.5 \mathrm{H}, 3^{\prime}-\mathrm{CH}_{\mathrm{A}}\right), 4.79\left(\mathrm{~m}, 0.12 \mathrm{H}, 2^{\prime}-\mathrm{CH}_{\text {ATP }}\right)$, $4.74\left(\mathrm{~m}, 1 \mathrm{H}, 4^{\prime}-\mathrm{CH}_{\mathrm{B}}\right), 4.58\left(\mathrm{dd}, J=5.0,3.3 \mathrm{~Hz}, 0.12 \mathrm{H}, 3^{\prime}-\mathrm{CH}_{\text {ATP }}\right), 4.52\left(\mathrm{~m}, 0.5 \mathrm{H}, 4^{\prime}-\mathrm{CH}_{\mathrm{A}}\right), 4.42-$ $4.35\left(\mathrm{~m}, 2 \mathrm{H}, 5^{\prime}-\mathrm{CH}_{2 \mathrm{~A}}, 5^{\prime}-\mathrm{CHH}_{\mathrm{B}}\right), 4.27\left(\mathrm{~d}, J=12.3 \mathrm{~Hz}, 1.12 \mathrm{H}, 5^{\prime}-\mathrm{CH}_{\mathrm{B}}, 5^{\prime}-\mathrm{CH} \mathrm{H}_{\text {ATP }}\right), 4.20$ (d, $\left.J=12.0 \mathrm{~Hz}, 0.12 \mathrm{H}, 55^{\prime}-\mathrm{CHH}_{\text {ATP }}\right), 3.18\left(\mathrm{q}, J=7.3 \mathrm{~Hz}, 22.5 \mathrm{H}, \mathrm{CH}_{2 \mathrm{NEt3}}\right), 1.26(\mathrm{t}, J=7.4 \mathrm{~Hz}, 33.75 \mathrm{H}$, $\left.\mathrm{CH}_{3 \mathrm{NEt}}\right) .{ }^{13} \mathrm{C}$ NMR $\left(\mathrm{D}_{2} \mathrm{O}, 151 \mathrm{MHz}\right): \delta(\mathrm{ppm})=165.7\left(1 \mathrm{C}, \mathrm{C}=\mathrm{O}_{\mathrm{B}}\right), 165.4\left(0.5 \mathrm{C}, \mathrm{C}=\mathrm{O}_{\mathrm{A}}\right), 155.8$

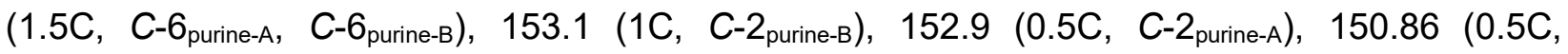
C-4 $\left.4_{\text {phenyl-A) }}\right), 150.82$ (1C, C-4 phenyl-B), 149.7 (1C,C-4 purine-B), 148.7 (0.5C, C-4 purine-A), 140.0 (1C,

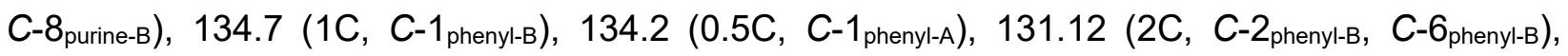
131.08 (1C, C-2 $\left.2_{\text {phenyl-A, }} C-6_{\text {phenyl-A }}\right), 129.6$ (0.34C, C-2 $\left.2_{\text {phenyl-C, }} C-6_{\text {phenyl-C }}\right), 123.9$ (3C, C-3 $3_{\text {phenyl-A, }}$ $\left.C-5_{\text {phenyl-A, }} C-3_{\text {phenyl-B }}, C-5_{\text {phenyl-B }}\right), 123.6$ (0.34C, $\left.C-3_{\text {phenyl-C, }} C-5_{\text {phenyl-C }}\right), 118.7$ (1C, $\left.C-5_{\text {purine-B }}\right), 85.9$

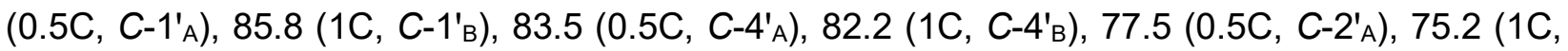




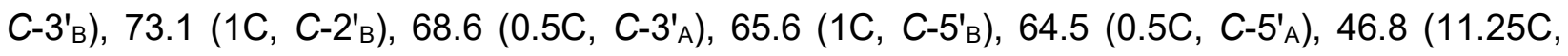
$\left.\mathrm{CH}_{2 \mathrm{NEt} 3}\right), 8.3\left(11.25 \mathrm{C}, \mathrm{CH}_{3 \mathrm{NEt}}\right) . \mathrm{C}-5_{\text {purine-A }}$ and $\mathrm{C}-8_{\text {purine-A }}$ could not be seen. ${ }^{31} \mathrm{P} \mathrm{NMR}$ (162 MHz, $\left.\mathrm{D}_{2} \mathrm{O} / \mathrm{D}_{3} \mathrm{PO}_{4}\right): \delta(\mathrm{ppm})=-11.2(2 \mathrm{P}, \alpha-\mathrm{P}$ and $\beta-\mathrm{P}),-22.3(1 \mathrm{P}, \mathrm{\gamma}-\mathrm{P})$.

2'-O-(Naphtho-1-yl)-adenosine 5'-(tetrahydrogene triphosphate) and 3'-O-(Naphtho-1-yl)adenosine 5'-(tetrahydrogene triphosphate) (20)

The mixture of the products was obtained as colorless solid after lyophilization (1.15 eq. Et $3 \mathrm{~N}$-salt [777.72 g/mol], 0.6:1 [A:B], $4 \mathrm{mg}, 5.1 \mu \mathrm{mol}, 0.5 \%$ ). $R_{t}$ (Sephadex HPLC): $15.8 \mathrm{~min}$. Solvent A: $\mathrm{CH}_{3} \mathrm{CN}$, solvent B: $0.1 \mathrm{M}$ TEAA, 0-1 min: $25 \%$ solvent A, $0.1 \mathrm{~mL} / \mathrm{min} \rightarrow 4 \mathrm{~mL} / \mathrm{min}, 1-50 \mathrm{~min}: 25 \%$ solvent A, 50-52 min: $25 \% \rightarrow 40 \%$ solvent $A, 52-70$ min: $40 \%$ solvent $A, 70-72$ min: $40 \% \rightarrow$ $25 \%$ solvent $A, 72-80$ min: $25 \%$ solvent $A, 80-81$ min: $25 \%$ solvent $A, 4 \mathrm{~mL} / \mathrm{min} \rightarrow 0.1 \mathrm{~mL} / \mathrm{min}$, Injection volume : 400-800 $\mu \mathrm{L}$. $R_{t}$ (RP-HPLC-C): $29.0 \mathrm{~min}$. Purity (HPLC-A): $>99 \%\left(R_{t}=\right.$ $12.7 \mathrm{~min})$. LC-MS: $\mathrm{m} / \mathrm{z}=$ calcd. for $\mathrm{C}_{21} \mathrm{H}_{21} \mathrm{~N}_{5} \mathrm{O}_{14} \mathrm{P}_{3} 660.0$, found $660.0[\mathrm{M}-\mathrm{H}]^{-}\left(R_{t}=5.70 \mathrm{~min}\right)$. Exact mass (ESI): $\mathrm{m} / \mathrm{z}=$ calcd. for $\mathrm{C}_{21} \mathrm{H}_{21} \mathrm{~N}_{5} \mathrm{O}_{14} \mathrm{P}_{3} 660.0303$, found 660.0323 [M-H] $]^{-}{ }^{1} \mathrm{H}$ NMR (DMSO$\left.\mathrm{d}_{6}, 600 \mathrm{MHz}\right): \delta(\mathrm{ppm})=8.84\left(\mathrm{~d}, J=8.7 \mathrm{~Hz}, 1 \mathrm{H}, 8-\mathrm{CH}_{\text {naphthoyl- }}\right), 8.70-8.60\left(\mathrm{~m}, 0.6 \mathrm{H}, 8-\mathrm{CH}_{\text {naphthoyl- }}\right.$ A), 8.60 and $8.55\left(\mathrm{~s}, 1 \mathrm{H}, 8-\mathrm{CH}_{\text {purine-B [syn and anti] }}\right), 8.53$ and $8.49\left(\mathrm{~s}, 0.6 \mathrm{H}, 8-\mathrm{CH}_{\text {purine-A [syn and anti] }}\right), 8.32$ (dd, $\left.J=7.2,1.3 \mathrm{~Hz}, 1 \mathrm{H}, 2-\mathrm{CH}_{\text {naphthoyl-B}}\right), 8.26-8.23\left(\mathrm{~m}, 1.6 \mathrm{H}, 2-\mathrm{CH}_{\text {naphthoyl-A, }}, 4-\mathrm{CH}_{\text {naphthoyl-B }}\right), 8.21$ (d, $\left.J=8.3 \mathrm{~Hz}, 0.6 \mathrm{H}, 4-\mathrm{CH}_{\text {naphthoyl-A }}\right), 8.20-8.17\left(\mathrm{~m}, 1.6 \mathrm{H}, 2-\mathrm{CH}_{\text {purine-A, }}, 2-\mathrm{CH}_{\text {purine- } \mathrm{B}}\right), 8.06(\mathrm{~d}, J=8.1 \mathrm{~Hz}$, $\left.1 \mathrm{H}, \quad 5-\mathrm{CH}_{\text {naphthoyl-B }}\right), \quad 8.04-8.02\left(\mathrm{~m}, 0.6 \mathrm{H}, 5-\mathrm{CH}_{\text {naphthoyl-A }}\right), 7.71-7.61\left(\mathrm{~m}, 2 \mathrm{H}, 3-\mathrm{CH}_{\text {naphthoyl-B, }}\right.$ 7-CH $\mathrm{CHaphthoyl-B}), 7.65-7.57\left(\mathrm{~m}, 2.8 \mathrm{H}, 3-\mathrm{CH}_{\text {naphthoyl-A, }}, 6-\mathrm{CH}_{\text {naphthoyl-A, }}, 7-\mathrm{CH}_{\text {naphthoyl-A, }}, 6-\mathrm{CH}_{\text {naphthoyl-B}}\right), 6.38$ (t, $J=4.5 \mathrm{~Hz}, 0.6 \mathrm{H}, 1^{\prime}-\mathrm{CH}_{\mathrm{A}}$ ), $6.07\left(\mathrm{~d}, J=7.3 \mathrm{~Hz}, 1 \mathrm{H}, 1^{\prime}-\mathrm{CH}_{\mathrm{B}}\right), 5.94$ (dt, $J=12.8,5.2 \mathrm{~Hz}, 0.6 \mathrm{H}$, $\left.2^{\prime}-\mathrm{CH}_{\mathrm{A} \text { [syn and anti] }}\right), 5.74-5.68\left(\mathrm{~m}, 1 \mathrm{H}, 3^{\prime}-\mathrm{CH}_{\mathrm{B}}\right), 5.12-5.06\left(\mathrm{~m}, 1 \mathrm{H}, 2^{\prime}-\mathrm{CH}_{\mathrm{B}}\right), 4.74(\mathrm{dt}, J=16.2,5.2 \mathrm{~Hz}$, $\left.0.6 \mathrm{H}, 3{ }^{\prime}-\mathrm{CH}_{\mathrm{A} \text { [syn and anti] }}\right), 4.51\left(\mathrm{~m}, 1 \mathrm{H}, 4^{\prime}-\mathrm{CH}_{\mathrm{B}}\right), 4.25\left(\mathrm{q}, J=4.5 \mathrm{~Hz}, 0.6 \mathrm{H}, 4^{\prime}-\mathrm{CH}_{\mathrm{A}}\right), 4.20-4.14(\mathrm{~m}$, $\left.1.6 \mathrm{H}, 5^{\prime}-\mathrm{CHH}_{\mathrm{A}}, 5^{\prime}-\mathrm{CHH}_{\mathrm{B}}\right), 4.14-4.07\left(\mathrm{~m}, 1.6 \mathrm{H}, 5^{\prime}-\mathrm{CH}_{\mathrm{A}}, 55^{\prime}-\mathrm{CH}_{\mathrm{B}}\right), 3.14-3.04\left(\mathrm{~m}, 11 \mathrm{H}, \mathrm{CH}_{2 \mathrm{NEt}}\right)$, $1.17\left(\mathrm{t}, J=7.2 \mathrm{~Hz}, 16.5 \mathrm{H}, \mathrm{CH}_{3 \mathrm{NEt}}\right)$. Signals at $9.19(\mathrm{~s}, 1.45 \mathrm{H}), 7.49(\mathrm{~s}, 1.8 \mathrm{H})$ and $7.42(\mathrm{~s}, 0.75 \mathrm{H})$ are $\mathrm{OH}$ - and $\mathrm{NH}_{2}$-groups. ${ }^{13} \mathrm{C}$ NMR (DMSO-d $\left.\mathrm{d}_{6}, 151 \mathrm{MHz}\right): \delta(\mathrm{ppm})=165.9\left(1 \mathrm{C}, \mathrm{C}=\mathrm{O}_{\mathrm{B}}\right), 165.7$ (0.6C, $\left.C=\mathrm{O}_{\mathrm{A}}\right), 155.7$ (1.6C, C-6 purine-A $\left._{1} C-6_{\text {purine-B}}\right), 152.5$ (1.6C, C-2 $\left.2_{\text {purine-A, }} C-2_{\text {purine-B }}\right), 149.8$ (1C, C-4 purine-B), 149.2 (0.6C, C-4 purine-A), 139.7 (0.6C, C-8 purine-A), 139.4 (1C, C-8 purine-B), 133.6 (0.6C, C-4naphthoyl-A), 133.42 (1C, C-4 naphthoyl-B), 133.39 (1C, C-1 naphthoyl-B), 133.33 (0.6C, C-1 naphthoyl-A), 130.6

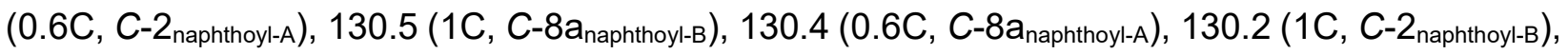
128.7 (1.6C, C-5 naphthoyl-A, $C-5_{\text {naphthoyl-B }),} 127.9$ (1.6C, C-7 naphthoyl-A, C-7 naphthoyl-B), 126.7 (1C,

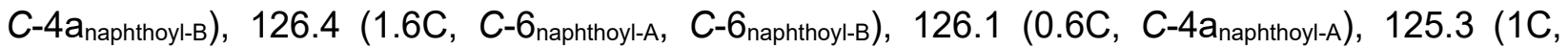
C-8naphthoyl-B), 125.2 (0.6C, C-8 naphthoyl-A), 125.0 (1C, C-3 $\left.3_{\text {naphthoyl-B) }}\right), 124.9$ (0.6C, C-3 $\left.3_{\text {naphthoyl-A }}\right), 118.8$ (0.6C, C-5 purine-A), $118.6\left(1 \mathrm{C}, C-5_{\text {purine-B }}\right), 86.3\left(1 \mathrm{C}, C-1_{B}{ }_{B}\right), 85.3\left(0.6 \mathrm{C}, C-1{ }_{A}^{\prime}\right), 83.8\left(0.6 \mathrm{C}, C-4_{A}^{\prime}\right)$, $81.6\left(1 \mathrm{C}, C-4_{\mathrm{B}}{ }_{\mathrm{B}}\right), 76.3\left(0.6 \mathrm{C}, \mathrm{C}-2^{\prime}{ }_{\mathrm{A}}\right), 74.8\left(1 \mathrm{C}, \mathrm{C}-3^{\prime}{ }_{\mathrm{B}}\right), 72.6\left(1 \mathrm{C}, \mathrm{C}-2^{\prime}{ }_{\mathrm{B}}\right), 68.9$ and $68.8\left(0.6 \mathrm{C}, \mathrm{C}-3^{\prime}{ }_{\mathrm{A} \text { [syn }}\right.$ 
and anti]), $65.3\left(1 \mathrm{C}, \mathrm{C}-5_{\mathrm{B}}^{\prime}\right), 64.8\left(0.6 \mathrm{C}, \mathrm{C}-5^{\prime}{ }_{\mathrm{A}}\right), 45.6\left(5.5 \mathrm{C}, \mathrm{CH}_{2 \mathrm{NEt} 3}\right), 8.6\left(5.5 \mathrm{C}, \mathrm{CH}_{3 \mathrm{NEt} 3}\right) .{ }^{31} \mathrm{P}$ NMR $\left(162 \mathrm{MHz}, \mathrm{D}_{2} \mathrm{O} / \mathrm{D}_{3} \mathrm{PO}_{4}\right): \delta(\mathrm{ppm})=-10.7,-11.4(2 \mathrm{P}, \alpha-\mathrm{P}$ and $\beta-\mathrm{P}),-23.1(1 \mathrm{P}, \mathrm{\gamma}-\mathrm{P})$.

2'-O-(Naphtho-2-yl)-adenosine 5'-(tetrahydrogene triphosphate) and 3'-O-(Naphtho-2-yl)adenosine 5'-(tetrahydrogene triphosphate) (21)

The mixture of the products was obtained as colorless solid after lyophilization (4.25 eq. Et ${ }_{3} \mathrm{~N}$-salt [1091.42 g/mol], 0.65:1 [A:B], $2 \mathrm{mg}, 1.8 \mu \mathrm{mol}, 0.2 \%$ ). $R_{t}$ (Sephadex-A): $15.5 \mathrm{~min} . R_{t}$ (RP-HPLCA): 35.2 min. Purity (HPLC-A): 99 \% ( $R_{t}=13.4$ min). LC-MS: $\mathrm{m} / \mathrm{z}=$ calcd. for $\mathrm{C}_{21} \mathrm{H}_{21} \mathrm{~N}_{5} \mathrm{O}_{14} \mathrm{P}_{3} 660.0$, found $660.0[\mathrm{M}-\mathrm{H}]^{-}\left(R_{t}=5.73 \mathrm{~min}\right)$. Exact mass $(\mathrm{ESI}): \mathrm{m} / \mathrm{z}=$ calcd. for $\mathrm{C}_{21} \mathrm{H}_{21} \mathrm{~N}_{5} \mathrm{O}_{14} \mathrm{P}_{3} 660.0303$, found $660.0299[\mathrm{M}-\mathrm{H}]^{-} .{ }^{1} \mathrm{H}$ NMR $\left(\mathrm{D}_{2} \mathrm{O}, 600 \mathrm{MHz}\right): \delta(\mathrm{ppm})=8.80\left(\mathrm{~s}, 1 \mathrm{H}, 1-\mathrm{CH}_{\text {naphthoyl-B}}\right), 8.67$ (s, $\left.0.65 \mathrm{H}, 1-\mathrm{CH}_{\text {naphthoyl-A }}\right), 8.63\left(\mathrm{~s}, 1 \mathrm{H}, 8-\mathrm{CH}_{\text {purine-B }}\right), 8.57\left(\mathrm{~s}, 0.65 \mathrm{H}, 8-\mathrm{CH}_{\text {purine-A }}\right), 8.23\left(\mathrm{~s}, 1 \mathrm{H}, 2-\mathrm{CH}_{\text {purine- }}\right.$ B), $8.17\left(\mathrm{~s}, 0.65 \mathrm{H}, 2-\mathrm{CH}_{\text {purine-A) }}\right), 8.13\left(\mathrm{dt}, J=8.7,1.5 \mathrm{~Hz}, 1 \mathrm{H}, 3-\mathrm{CH}_{\text {naphthoyl-B}}\right), 8.10$ (d, J = 8.2 Hz, $\left.1 \mathrm{H}, 8-\mathrm{CH}_{\text {naphthoyl-B }}\right), 8.05-8.02\left(\mathrm{~m}, 1.65 \mathrm{H}, 8-\mathrm{CH}_{\text {naphthoyl-A, }} 4-\mathrm{CH}_{\text {naphthoyl-B }}\right), 8.02-7.99(\mathrm{~m}, 1.65 \mathrm{H}$,

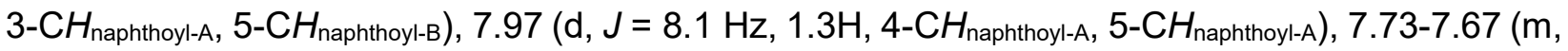
$1.65 \mathrm{H}, 6-\mathrm{CH}_{\text {naphthoyl-A, }} 6-\mathrm{CH}_{\text {naphthoyl-B) }}, 7.67-7.61\left(\mathrm{~m}, 1.65 \mathrm{H}, 7-\mathrm{CH}_{\text {naphthoyl-A, }} 7-\mathrm{CH}_{\text {naphthoyl-B}}\right), 6.50$ (d, $\left.J=4.1 \mathrm{~Hz}, 0.65 \mathrm{H}, 1^{\prime}-\mathrm{CH}_{\mathrm{A}}\right), 6.38\left(\mathrm{~d}, J=7.8 \mathrm{~Hz}, 1 \mathrm{H}, 1^{\prime}-\mathrm{CH}_{\mathrm{B}}\right), 5.88\left(\mathrm{~d}, J=5.0 \mathrm{~Hz}, 1 \mathrm{H}, 3^{\prime}-\mathrm{CH}_{\mathrm{B}}\right), 5.84$ (t, $\left.J=4.8 \mathrm{~Hz}, 0.65 \mathrm{H}, 2^{\prime}-\mathrm{CH}_{\mathrm{A}}\right), 5.22$ (dd, $\left.J=7.5,5.4 \mathrm{~Hz}, 1 \mathrm{H}, 2^{\prime}-\mathrm{CH}_{\mathrm{B}}\right), 4.94$ (t, J = 5.6 Hz, $0.65 \mathrm{H}$, 3'- $\left.\mathrm{CH}_{\mathrm{A}}\right), 4.79\left(\mathrm{~m}, 1 \mathrm{H}, 4^{\prime}-\mathrm{CH}_{\mathrm{B}}\right), 4.58-4.56\left(\mathrm{~m}, 0.65 \mathrm{H}, 44^{\prime}-\mathrm{CH}_{\mathrm{A}}\right), 4.45-4.40\left(\mathrm{~m}, 2.3 \mathrm{H}, 5{ }^{\prime}-\mathrm{CHH}_{\mathrm{A}}\right.$, 5'-CH $\mathrm{CH}_{2 \mathrm{~B}}$ ), 4.34-4.29 (m, 0.65H, 5'-CHH $\mathrm{A}_{\mathrm{A}}, 3.18$ (q, J = 7.4 Hz, 42.1H, $\left.\mathrm{CH}_{2 \mathrm{NEt} 3}\right), 1.26$ (t, J = 7.3 Hz, 63.1H, $\left.\mathrm{CH}_{3 \mathrm{NE}+3}\right) .{ }^{13} \mathrm{C}$ NMR $\left(\mathrm{D}_{2} \mathrm{O}, 151 \mathrm{MHz}\right): \delta(\mathrm{ppm})=167.6\left(1 \mathrm{C}, C=\mathrm{O}_{\mathrm{B}}\right), 167.3\left(0.65 \mathrm{C}, C=\mathrm{O}_{\mathrm{A}}\right)$,

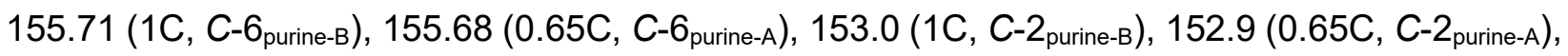
149.6 (1C, C-4 purine-B), 148.7 (0.65C, C-4 purine-A), 140.0 (1.65C, C-8 purine-A, $_{\text {C-8 }}$ purine-B), 135.7 (1.65C, C-4a $a_{\text {naphthoyl-A, }} C-4 a_{\text {naphthoyl-B) }}, 132.2$ (1C, C-8 $\left.a_{\text {naphthoyl-B }}\right), 132.1$ (0.65C, C-8 $\left.a_{\text {naphthoyl-A }}\right), 131.84$ (0.65C, C-1 naphthoyl-A), 131.75 (1C,C-1 naphthoyl-B), 129.5 (1.65C,C-8 naphthoyl-A, C-8 naphthoyl-B), 129.2 (0.65C,

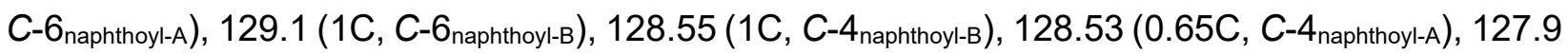
(1C, C-5 naphthoyl-B), 127.8 (0.65C, C-5 naphthoyl-A), 127.26 (0.65C, C-7 naphthoyl-A), 127.24 (1C,

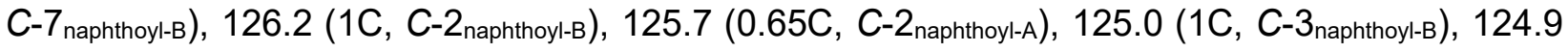

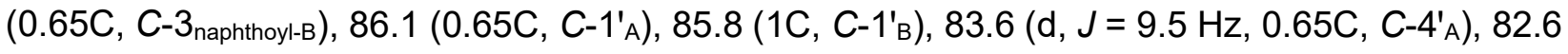
$\left(\mathrm{d}, J=9.0 \mathrm{~Hz}, 1 \mathrm{C}, \mathrm{C}-4_{\mathrm{B}}^{\prime}\right), 77.1\left(0.65 \mathrm{C}, C-2^{\prime} \mathrm{A}\right), 74.9$ (1C, C-3'B), $73.2\left(1 \mathrm{C}, C-2_{\mathrm{B}}^{\prime}\right), 68.5(0.65 \mathrm{C}$, $\left.C-3^{\prime}{ }_{A}\right), 65.7\left(\mathrm{~d}, J=5.1 \mathrm{~Hz}, 1 \mathrm{C}, C-5_{\mathrm{B}}^{\prime}\right), 64.5$ (d, J = 4.0 Hz, 0.65C, C-5'A), 46.7 (12.75C, $\mathrm{CH}_{2} \mathrm{NEt}_{3}$ ), $8.3\left(12.75 \mathrm{C}, \mathrm{CH}_{3 \mathrm{NEt} 3}\right)$. $C-5_{\text {purine-A }}$ and $C-5_{\text {purine-B }}$ could not be seen. ${ }^{31} \mathrm{P} \mathrm{NMR}(162 \mathrm{MHz}$, $\left.\mathrm{D}_{2} \mathrm{O} / \mathrm{D}_{3} \mathrm{PO}_{4}\right): \delta(\mathrm{ppm})=-8.2(1 \mathrm{P}, \alpha-\mathrm{P}),-11.2$ and $-11.3(1 \mathrm{P}, \beta-\mathrm{P}),-22.5(1 \mathrm{P}, \mathrm{\gamma}-\mathrm{P})$.

2'-O-(9-Oxo-9H-fluorene-2-carbonyl)-adenosine 5'-(tetrahydrogene triphosphate) and 3'-O-(9-Oxo-9H-fluorene-2-carbonyl)-adenosine 5'-(tetrahydrogene triphosphate) (22) 
The mixture of the products was obtained as yellow solid after lyophilization (1.9 eq. Et ${ }_{3} \mathrm{~N}$-salt [902.27 g/mol], 0.5:1 [A:B], $9.5 \mathrm{mg}, 10.5 \mu \mathrm{mol}, 1 \%$ ). $R_{t}$ (Sephadex-B): $16.5 \mathrm{~min} . R_{t}(\mathrm{RP}-\mathrm{HPLC}-\mathrm{B})$ : 36.8 min. Purity (HPLC-B): $97 \%$ ( $R_{t}=7.0 \mathrm{~min}$ ). LC-MS: $\mathrm{m} / \mathrm{z}=$ calcd. for $\mathrm{C}_{24} \mathrm{H}_{21} \mathrm{~N}_{5} \mathrm{O}_{15} \mathrm{P}_{3} 712.0$, found $712.0[\mathrm{M}-\mathrm{H}]^{-}\left(R_{t}=5.86 \mathrm{~min}\right)$. Exact mass $(\mathrm{ESI}): \mathrm{m} / \mathrm{z}=$ calcd. for $\mathrm{C}_{24} \mathrm{H}_{21} \mathrm{~N}_{5} \mathrm{O}_{15} \mathrm{P}_{3} 712.0252$, found $712.0258[\mathrm{M}-\mathrm{H}]^{-} .{ }^{1} \mathrm{H}$ NMR $\left(\mathrm{D}_{2} \mathrm{O}, 400 \mathrm{MHz}\right): \delta(\mathrm{ppm})=8.65\left(\mathrm{~s}, 1.5 \mathrm{H}, 8-\mathrm{CH}_{\text {purine-A, }} 8-\mathrm{CH}_{\text {purine- }}\right.$ B), $8.52\left(\mathrm{~s}, 1.5 \mathrm{H}, 2-\mathrm{CH}_{\text {purine-A }}, 2-\mathrm{CH}_{\text {purine-B }}\right), 7.63\left(\mathrm{~m}, 0.5 \mathrm{H}, 3-\mathrm{CH}_{\text {fluorenone-A }}\right), 7.55(\mathrm{~m}, 1 \mathrm{H}$, 3- $\left.\mathrm{CH}_{\text {fluorenone-B }}\right), 7.48\left(\mathrm{~m}, 1 \mathrm{H}, 6-\mathrm{CH}_{\text {fluorenone-B }}\right), 7.39\left(\mathrm{~m}, 1.5 \mathrm{H}, 6-\mathrm{CH}_{\text {fluorenone-A, }}\right.$ 7- $\left.\mathrm{CH}_{\text {fluorenone-B }}\right), 7.29-$ $7.24\left(\mathrm{~m}, 1.5 \mathrm{H}, 7-\mathrm{CH}_{\text {fluorenone-A, }} 8-\mathrm{CH}_{\text {fluorenone-B }}\right), 7.21\left(\mathrm{~m}, 0.5 \mathrm{H}, 8-\mathrm{CH}_{\text {fluorenone-A }}\right), 7.17-7.11(\mathrm{~m}, 1.5 \mathrm{H}$, 5- $\left.\mathrm{CH}_{\text {fluorenone-A, }} 5-\mathrm{CH}_{\text {fluorenone-B }}\right), 7.05\left(\mathrm{~m}, 0.5 \mathrm{H}, 4-\mathrm{CH}_{\text {fluorenone-A }}\right), 6.95\left(\mathrm{~m}, 1 \mathrm{H}, 4-\mathrm{CH}_{\text {fluorenone-B }}\right), 6.14(\mathrm{~m}$, $\left.0.5 \mathrm{H}, 1^{\prime}-\mathrm{CH}_{\mathrm{A}}\right), 6.10\left(\mathrm{~d}, J=7.7 \mathrm{~Hz}, 1 \mathrm{H}, 1^{\prime}-\mathrm{CH}_{\mathrm{B}}\right), 5.42\left(\mathrm{~s}, 0.5 \mathrm{H}, 2^{\prime}-\mathrm{CH}_{\mathrm{A}}\right), 5.40(\mathrm{~d}, J=5.3 \mathrm{~Hz}$, $\left.1 \mathrm{H}, 3^{\prime}-\mathrm{CH}_{\mathrm{B}}\right), 5.02\left(\mathrm{~m}, 1 \mathrm{H}, 2^{\prime}-\mathrm{CH}_{\mathrm{B}}\right), 4.93-4.85\left(\mathrm{~m}, 0.5 \mathrm{H}, 3{ }^{\prime}-\mathrm{CH}_{\mathrm{A}}\right), 4.71\left(\mathrm{~m}, 0.5 \mathrm{H}, 5{ }^{\prime}-\mathrm{CHH}_{\mathrm{A}}\right), 4.68-4.62$ $\left(\mathrm{m}, 1 \mathrm{H}, 4^{\prime}-\mathrm{CH}_{\mathrm{B}}\right), 4.59\left(\mathrm{~m}, 1 \mathrm{H}, 5^{\prime}-\mathrm{CHH}_{\mathrm{B}}\right), 4.53\left(\mathrm{~m}, 0.5 \mathrm{H}, 4^{\prime}-\mathrm{CH}_{\mathrm{A}}\right), 4.49-4.39\left(\mathrm{~m}, 1.5 \mathrm{H}, 5^{\prime}-\mathrm{CH}_{\mathrm{A}}, 5^{\prime}-\right.$ $\mathrm{CH}_{\mathrm{B}}$ ), 3.18 (q, $\left.J=7.3 \mathrm{~Hz}, 16.8 \mathrm{H}, \mathrm{CH}_{2 \mathrm{NEt} 3}\right), 1.26$ (t, $\left.J=7.4 \mathrm{~Hz}, 25.2 \mathrm{H}, \mathrm{CH}_{3 \mathrm{NEt} 3}\right)$. Two signals (7.45 $(\mathrm{s}, 0.5 \mathrm{H})$ and $7.21(\mathrm{~s}, 1 \mathrm{H})$ correlate to $1-\mathrm{CH}_{\text {fluorenone-A }}$ and 1- $\mathrm{CH}_{\text {fluorenone-B }}$ but cannot be distiguished. ${ }^{13} \mathrm{C}$ NMR $\left(\mathrm{D}_{2} \mathrm{O}, 151 \mathrm{MHz}\right): \delta(\mathrm{ppm})=194.2\left(0.5 \mathrm{C}, \mathrm{C}-9_{\text {fluorenone-A }}\right), 194.1$ (1C, C-9 $\left.9_{\text {fluorenone-B }}\right), 165.4$ (1C, $\left.C=\mathrm{O}_{\mathrm{B}}\right), 164.8\left(0.5 \mathrm{C}, C=\mathrm{O}_{\mathrm{A}}\right), 150.3$ (1.5C,C-6 purine-A $\left._{\text {A }} C-6_{\text {purine-B }}\right), 148.5$ (1.5C, C-4 $4_{\text {purine-A, }}$ $\left.C-4_{\text {purine-B }}\right), 148.4$ (1.5C, C-4a $\left.a_{\text {fluorenone-A }}, C-4 a_{\text {fluorenone-B }}\right), 142.6\left(1.5 \mathrm{C}, C-4 b_{\text {fluorenone-A }}, C-4 b_{\text {fluorenone-B }}\right)$,

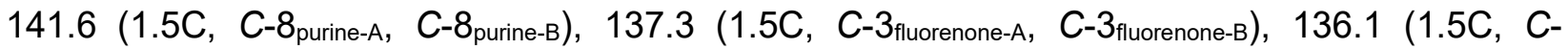

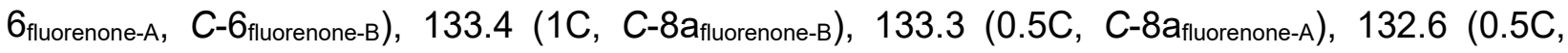
$\left.C-2_{\text {fluorenone-A }}\right), 132.5$ (1C, C-2 fluorenone-B), 130.7 (1.5C, C-7 fluorenone-A, C-7 fluorenone-B), 128.6 (1C, C-9a fluorenone-B), 128.3 (0.5C, C-9a fluorenone-A), 124.3 (1.5C, C-8 fluorenone-A, $C-8_{\text {fluorenone-B) }} 122.0$ (1.5C, C-5 fluorenone-A, C-5 fluorenone-B), 120.7 (1.5C, C-4 fluorenone-A, C-4 fluorenone-B), $86.8\left(0.5 \mathrm{C}, C-1^{\prime} \mathrm{A}\right), 85.2(1 \mathrm{C}$, $\left.C-1{ }_{\mathrm{B}}\right), 83.0\left(1 \mathrm{C}, C-4_{\mathrm{B}}^{\prime}\right), 82.1\left(0.5 \mathrm{C}, C-4_{\mathrm{A}}{ }_{\mathrm{A}}\right), 77.1\left(0.5 \mathrm{C}, C-2^{\prime}{ }_{\mathrm{A}}\right), 76.2\left(1 \mathrm{C}, C-3_{\mathrm{B}}^{\prime}\right), 73.4\left(1 \mathrm{C}, C-2_{\mathrm{B}}^{\prime}\right)$, 66.7 (0.5C, C-3'A), 65.9 (1C, C-5'B), $63.4\left(0.5 \mathrm{C}, C-5{ }^{\prime} \mathrm{A}\right), 46.7\left(8.4 \mathrm{C}, \mathrm{CH}_{2}{ }_{\mathrm{NEt} 3}\right), 8.3\left(8.4 \mathrm{C}, \mathrm{CH}_{3 \mathrm{NEt}}\right)$. $C-2_{\text {purine-A, }}, C-2_{\text {purine-B, }} \quad C-5_{\text {purine-A }}, C-5_{\text {purine-B }}, C-1_{\text {fluorenone-A }}$ and $C-1_{\text {fluorenone-B }}$ could not be seen. ${ }^{31} \mathrm{P}$ NMR $\left(162 \mathrm{MHz}, \mathrm{D}_{2} \mathrm{O} / \mathrm{D}_{3} \mathrm{PO}_{4}\right): \delta(\mathrm{ppm})=-10.8(2 \mathrm{P}, \alpha-\mathrm{P}$ and $\beta-\mathrm{P}),-22.6(1 \mathrm{P}, \mathrm{y}-\mathrm{P})$.

2'-O-(2-(Adamantan-1-yl)acetyl)-adenosine 5'-(tetrahydrogene triphosphate) and 3'-O-(2-(Adamantan-1-yl)acetyl)-adenosine 5'-(tetrahydrogene triphosphate) (23)

The mixture of the products was obtained as colorless solid after lyophilization (1.88 eq. Et ${ }_{3} \mathrm{~N}$-salt [873.68 g/mol], 1:0.55 [A:B], 2 mg, $2.3 \mu \mathrm{mol}, 0.2 \%$ ). $R_{t}$ (RP-HPLC-A): $31.9 \mathrm{~min}$. Purity (HPLC-A): $>99 \%\left(R_{t}=13.1 \mathrm{~min}[47 \%]\right.$ and $\left.R_{t}=13.3 \mathrm{~min}[53 \%]\right)$. LC-MS: $\mathrm{m} / \mathrm{z}=$ calcd. for $\mathrm{C}_{22} \mathrm{H}_{31} \mathrm{~N}_{5} \mathrm{O}_{14} \mathrm{P}_{3}$ 682.1, found $682.2[\mathrm{M}-\mathrm{H}]^{-}\left(R_{t}=5.76 \mathrm{~min}\right)$. Exact mass $(\mathrm{ESI}): \mathrm{m} / \mathrm{z}=$ calcd. for $\mathrm{C}_{22} \mathrm{H}_{31} \mathrm{~N}_{5} \mathrm{O}_{14} \mathrm{P}_{3}$ 682.1086, found 628.1087 [M-H]- . ${ }^{1} \mathrm{H}$ NMR $\left(\mathrm{D}_{2} \mathrm{O}, 600 \mathrm{MHz}\right): \delta(\mathrm{ppm})=8.64\left(\mathrm{~s}, 1.55 \mathrm{H}, 8-\mathrm{CH}_{\text {purine- }}\right.$

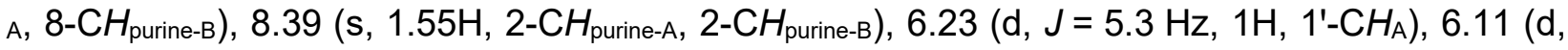


$\left.J=7.2 \mathrm{~Hz}, 0.55 \mathrm{H}, 1^{\prime}-\mathrm{CH}_{\mathrm{B}}\right), 5.60\left(\mathrm{t}, J=5.6 \mathrm{~Hz}, 1 \mathrm{H}, 2^{\prime}-\mathrm{CH}_{\mathrm{A}}\right), 5.45\left(\mathrm{~d}, J=5.0 \mathrm{~Hz}, 0.55 \mathrm{H}, 3^{\prime}-\mathrm{CH}_{\mathrm{B}}\right)$, $4.95\left(\mathrm{t}, J=6.1 \mathrm{~Hz}, 0.55 \mathrm{H}, 2^{\prime}-\mathrm{CH}_{\mathrm{B}}\right), 4.75-4.71\left(\mathrm{~m} \mathrm{1H}, 3^{\prime}-\mathrm{CH}_{\mathrm{A}}\right), 4.56\left(\mathrm{~m}, 0.55 \mathrm{H}, 4^{\prime}-\mathrm{CH}_{\mathrm{B}}\right), 4.44(\mathrm{~m}$, $\left.1 \mathrm{H}, 4^{\prime}-\mathrm{CH}_{\mathrm{A}}\right), 4.38\left(\mathrm{~d}, J=11.3 \mathrm{~Hz}, 1 \mathrm{H}, 5^{\prime}-\mathrm{CHH}_{\mathrm{A}}\right), 4.35-4.22\left(\mathrm{~m}, 2.1 \mathrm{H}, 5^{\prime}-\mathrm{CHH}_{\mathrm{A}}, 5^{\prime}-\mathrm{CH}_{2 \mathrm{~B}}\right), 3.18(\mathrm{q}$, $\left.J=7.3 \mathrm{~Hz}, 17.5 \mathrm{H}, \mathrm{CH}_{2 \mathrm{NEt}}\right), 2.29\left(\mathrm{~d}, J=12.8 \mathrm{~Hz}, 0.55 \mathrm{H}, \mathrm{CHH}(\mathrm{C}=\mathrm{O})_{\mathrm{B}}\right), 2.24(\mathrm{~d}, J=15.6 \mathrm{~Hz}$, $\left.0.55 \mathrm{H}, \mathrm{CH}(\mathrm{C}=\mathrm{O})_{\mathrm{B}}\right), 2.24-2.20\left(\mathrm{~m}, 1 \mathrm{H}, \mathrm{CHH}(\mathrm{C}=\mathrm{O})_{\mathrm{A}}\right), 2.08\left(\mathrm{~d}, J=12.5 \mathrm{~Hz}, 1 \mathrm{H}, \mathrm{CH}(\mathrm{C}=\mathrm{O})_{\mathrm{A}}\right), 1.97$ $\left(\mathrm{m}, 1.65 \mathrm{H}, 3,5,7-\mathrm{CH}_{\text {adamantyl-B) }}, 1.80\left(\mathrm{~m}, 3 \mathrm{H}, 3,5,7-\mathrm{CH}_{\text {adamantyl-A }}\right), 1.72(\mathrm{~d}, J=12.0 \mathrm{~Hz}, 1.65 \mathrm{H}, 4,6,10-\right.$ $\left.\mathrm{C} H \mathrm{H}_{\text {adamantyl-B }}\right), 1.70-1.60\left(\mathrm{~m}, 7.95 \mathrm{H}, 4,6,10-\mathrm{CHH}_{\text {adamantyl-A, }}, 2,8,9-\mathrm{CH}_{2}\right.$ adamantyl-B, $4,6,10-\mathrm{CH} H_{\text {adamantyl- }}$

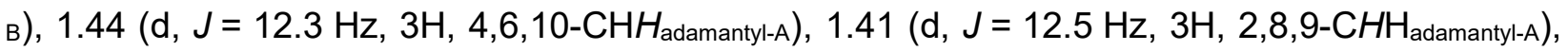
$1.36\left(\mathrm{~d}, J=12.6 \mathrm{~Hz}, 3 \mathrm{H}, 2,8,9-\mathrm{CH} H_{\text {adamantyl-A }}\right), 1.26\left(\mathrm{t}, J=7.3 \mathrm{~Hz}, 26.25 \mathrm{H}, \mathrm{CH}_{3 \mathrm{NEt}}\right) .{ }^{13} \mathrm{C} \mathrm{NMR}$ $\left(\mathrm{D}_{2} \mathrm{O}, 151 \mathrm{MHz}\right): \delta(\mathrm{ppm})=173.9\left(1 \mathrm{C}, \mathrm{C}=\mathrm{O}_{\mathrm{A}}\right), 173.2\left(0.55 \mathrm{C}, \mathrm{C}=\mathrm{O}_{\mathrm{B}}\right), 150.7\left(1.55 \mathrm{C}, \mathrm{C}-6_{\text {purine-A, }}\right.$ $\left.C-6_{\text {purine-B }}\right), 146.3$ (1.55C, C-2 $\left.2_{\text {purine-A, }} C-2_{\text {purine-A }}\right), 142.3$ (s) and 142.1 (1.55C, C-8 purine-A, $\left.C-8_{\text {purine-B }}\right)$, $86.7\left(0.55 \mathrm{C}, C-1_{\mathrm{B}}^{\prime}\right), 85.8\left(1 \mathrm{C}, C-1_{\mathrm{A}}^{\prime}\right), 84.5\left(\mathrm{~d}, J=10.4 \mathrm{~Hz}, 1 \mathrm{C}, C-4_{\mathrm{A}}^{\prime}\right), 83.1\left(0.55 \mathrm{C}, C-4_{\mathrm{B}}^{\prime}\right), 76.0$ (1C, C-2' $\left.{ }_{\mathrm{A}}\right), 73.9\left(0.55 \mathrm{C}, C-3^{\prime} \mathrm{B}\right), 73.5\left(0.55 \mathrm{C}, \mathrm{C}-2^{\prime}{ }_{\mathrm{B}}\right), 68.8\left(1 \mathrm{C}, C-3^{\prime}{ }_{\mathrm{A}}\right), 65.6(\mathrm{~d}, J=3.3 \mathrm{~Hz}, 0.55 \mathrm{C}$, $\left.C-5^{\prime}{ }_{B}\right), 65.0\left(\mathrm{~d}, J=4.0 \mathrm{~Hz}, 1 \mathrm{C}, C_{-5}{ }^{\prime} \mathrm{A}\right), 48.7\left(0.55 \mathrm{C}, \mathrm{CH}_{2}(\mathrm{C}=\mathrm{O})_{\mathrm{B}}\right), 48.3\left(1 \mathrm{C}, \mathrm{CH}_{2}(\mathrm{C}=\mathrm{O})_{\mathrm{A}}\right), 46.7$

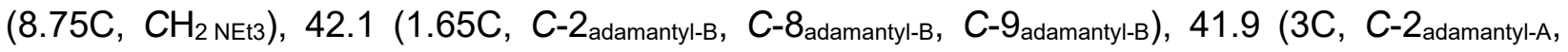

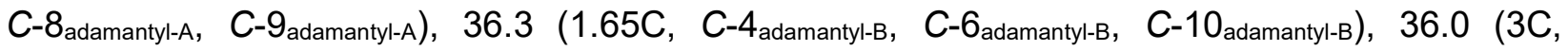
C-4 adamantyl-A, C-6 adamantyl-A, $_{\text {a }} \quad$-10 $\left._{\text {adamantyl-A }}\right), 32.9$ (0.55C, C-1 adamantyl-B $), 32.7$ (C-1 adamantyl-A $\left._{\text {a }}\right), 28.5$ (1.65C, $\left.C-3_{\text {adamantyl-B, }} C-5_{\text {adamantyl-B, }} C-7_{\text {adamantyl-B }}\right), 28.4$ (3C, $C$-3 $3_{\text {adamantyl-A, }} C-5_{\text {adamantyl-A, }} C-7_{\text {adamantyl-A }}$ ), $8.3\left(8.75 \mathrm{C}, \mathrm{CH}_{3} \mathrm{NEt3}\right) .{ }^{31} \mathrm{P} \mathrm{NMR}\left(162 \mathrm{MHz}, \mathrm{D}_{2} \mathrm{O} / \mathrm{D}_{3} \mathrm{PO}_{4}\right): \delta(\mathrm{ppm})=-10.8(2 \mathrm{P}, \alpha-P, \beta-P) . \gamma-P$ could not be seen.

3', 4'-O-Bisbenzoyl-adenosine 5'-(tetrahydrogene triphosphate) (24)

The product was obtained as colorless solid after lyophilization (2.33 eq. Et ${ }_{3} \mathrm{~N}$-salt [951.51 g/mol], $41 \mathrm{mg}, 43 \mu \mathrm{mol}, 4.3 \%$ ). $R_{t}$ (Sephadex-C): $16.2 \mathrm{~min} . R_{t}$ (RP-HPLC-D): $24.2 \mathrm{~min}$. Purity (HPLC-B): $98 \%\left(R_{t}=13.5 \mathrm{~min}\right)$. LC-MS: $\mathrm{m} / \mathrm{z}=$ calcd. for $\mathrm{C}_{24} \mathrm{H}_{23} \mathrm{~N}_{5} \mathrm{O}_{15} \mathrm{P}_{3} 714.0$, found $714.0[\mathrm{M}-\mathrm{H}]^{-}$ $\left(R_{t}=5.79 \mathrm{~min}\right)$. Exact mass $(\mathrm{ESI}): \mathrm{m} / \mathrm{z}=$ calcd. for $\mathrm{C}_{24} \mathrm{H}_{23} \mathrm{~N}_{5} \mathrm{O}_{15} \mathrm{P}_{3} 714.0409$, found 714.0411 $[\mathrm{M}-\mathrm{H}]^{-} .{ }^{1} \mathrm{H}$ NMR $\left(\mathrm{D}_{2} \mathrm{O}, 600 \mathrm{MHz}\right): \delta(\mathrm{ppm})=8.68\left(\mathrm{~s}, 1 \mathrm{H}, 8-\mathrm{CH}_{\text {purine }}\right), 8.19\left(\mathrm{~s}, 1 \mathrm{H}, 2-\mathrm{CH}_{\text {purine }}\right), 7.74$ (d, $J=7.5 \mathrm{~Hz}, 2 \mathrm{H}, 2,6-\mathrm{CH}_{\text {phenyl-B) }}, 7.42\left(\mathrm{~d}, J=7.7 \mathrm{~Hz}, 3 \mathrm{H}, 2,6-\mathrm{CH}_{\text {phenyl-A, }}, 4-\mathrm{CH}_{\text {phenyl-B) }}, 7.18(\mathrm{~m}, 2 \mathrm{H}\right.$, 3,5- $\left.\mathrm{CH}_{\text {phenyl-B }}\right), 7.08\left(\mathrm{~m}, 1 \mathrm{H}, 4-\mathrm{CH}_{\text {phenyl-A }}\right), 7.84\left(\mathrm{~m}, 2 \mathrm{H}, 3,5-\mathrm{CH}_{\text {phenyl-A }}\right), 6.42\left(\mathrm{~d}, J=6.0 \mathrm{~Hz}, 1 \mathrm{H}, 1^{\prime}-\right.$ $\mathrm{CH}), 6.10\left(\mathrm{t}, \mathrm{J}=5.4 \mathrm{~Hz}, 1 \mathrm{H}, 2^{\prime}-\mathrm{CH}\right), 6.00\left(\mathrm{~m}, 1 \mathrm{H}, 3^{\prime}-\mathrm{CH}\right), 4.84\left(\mathrm{~m}, 1 \mathrm{H}, 4^{\prime}-\mathrm{CH}\right), 4.47\left(\mathrm{~m}, 2 \mathrm{H}, 5^{\prime}-\mathrm{CH}_{2}\right)$, $3.17\left(\mathrm{q}, J=7.1 \mathrm{~Hz}, 14 \mathrm{H}, \mathrm{CH}_{2 \mathrm{NEt}}\right), 1.26\left(\mathrm{t}, J=7.0 \mathrm{~Hz}, 21 \mathrm{H}, \mathrm{CH}_{3 \mathrm{NEt}}\right) .{ }^{13} \mathrm{C} \mathrm{NMR}\left(\mathrm{D}_{2} \mathrm{O}, 151 \mathrm{MHz}\right): \delta$ $(\mathrm{ppm})=166.5\left(1 \mathrm{C}, C=\mathrm{O}_{\mathrm{B}}\right), 165.9\left(1 \mathrm{C}, \mathrm{C}=\mathrm{O}_{\mathrm{A}}\right), 152.3\left(1 \mathrm{C}, \mathrm{C}-2_{\text {purine }}\right), 148.7$ (1C,C-4 $\left.4_{\text {purine }}\right), 141.4$ (1C, C-8 $\left.8_{\text {purine }}\right), 134.1$ (1C, C-4 phenyl-B), 133.8 (1C,C-4 phenyl-A), 129.5 (2C, C- phenyl-B, $_{\text {p- }}$ phenyl-B $\left._{\text {B }}\right), 129.3$ (2C, C-2 phenyl-A, $_{\text {C- }}$ phenyl-A) $) 128.6$ (2C, C-3 $\left.3_{\text {phenyl-B }}, C-5_{\text {phenyl-B }}\right), 128.3$ (2C, C- $3_{\text {phenyl-A }}, C-5_{\text {phenyl-A }}$ ), 128.1 (1C, $C$ - $1_{\text {phenyl-B) }}, 127.5$ (1C, C-1 phenyl-A), 85.5 (1C, C-1'), 82.4 (d, J=8.1 Hz, 1C, C-4'), 74.7 
(1C, C-3'), 72.3 (1C, $\left.C-2^{\prime}\right), 65.5$ (1C, C-5'), 46.7 (7C, $\left.\mathrm{CH}_{2 \mathrm{NEt}}\right), 8.3$ (7C, $\left.\mathrm{CH}_{3 \mathrm{NEt}}\right) . \mathrm{C}-6_{\text {purine }}$ and $C-5_{\text {purine }}$ could not be seen. ${ }^{31} \mathrm{P}$ NMR $\left(160 \mathrm{MHz}, \mathrm{D}_{2} \mathrm{O} / \mathrm{D}_{3} \mathrm{PO} \mathrm{O}_{4}\right): \delta(\mathrm{ppm})=-11.2(2 \mathrm{P}, \alpha-\mathrm{P}, \beta-\mathrm{P}),-22.7$ $(1 \mathrm{P}, \mathrm{y}-\mathrm{P})$.

2',3'-O-Bis(4-methoxybenzoyl)-adenosine 5'-(tetrahydrogene triphosphate) (25)

The product was obtained as colorless solid after lyophilization (3 eq. NEt 3 -salt [1079.03 g/mol], $11 \mathrm{mg}, 10 \mu \mathrm{mol}, 1 \%$ ). $R_{t}$ (Sephadex-B): $18.3 \mathrm{~min}$. $R_{t}$ (RP-HPLC-C): 30.9 min. Purity (HPLC-A): $99 \%\left(R_{t}=14.1 \mathrm{~min}\right)$. LC-MS: $\mathrm{m} / \mathrm{z}=$ calcd. for $\mathrm{C}_{26} \mathrm{H}_{27} \mathrm{~N}_{5} \mathrm{O}_{17} \mathrm{P}_{3} 774.1$, found $774.0[\mathrm{M}-\mathrm{H}]^{-}$ $\left(R_{t}=5.77 \mathrm{~min}\right.$ ). Exact mass $(\mathrm{ESI}): \mathrm{m} / \mathrm{z}=$ calcd. for $\mathrm{C}_{26} \mathrm{H}_{27} \mathrm{~N}_{5} \mathrm{O}_{17} \mathrm{P}_{3} 774.0620$, found 774.0625 $[\mathrm{M}-\mathrm{H}]^{-} .{ }^{1} \mathrm{H}$ NMR $\left(\mathrm{D}_{2} \mathrm{O}, 600 \mathrm{MHz}\right): \delta(\mathrm{ppm})=8.65\left(\mathrm{~s}, 1 \mathrm{H}, 8-\mathrm{CH}_{\text {purine }}\right), 8.14\left(\mathrm{~s}, 1 \mathrm{H}, 2-\mathrm{CH}_{\text {purine }}\right), 7.82$ (d, $\left.J=8.4 \mathrm{~Hz}, 2 \mathrm{H}, 2,6-\mathrm{CH}_{\text {phenyl-B) }}\right), 7.51$ (d, $\left.J=8.4 \mathrm{~Hz}, 2 \mathrm{H}, 2,6-\mathrm{CH}_{\text {phenyl-A }}\right), 6.77$ (d, $J=8.4 \mathrm{~Hz}, 2 \mathrm{H}$, $\left.3,5-\mathrm{CH}_{\text {phenyl-B }}\right), 6.52\left(\mathrm{~d}, J=6.6 \mathrm{~Hz}, 1 \mathrm{H}, 1^{\prime}-\mathrm{CH}\right), 6.49\left(\mathrm{~d}, J=8.6 \mathrm{~Hz}, 2 \mathrm{H}, 3,5-\mathrm{CH}_{\text {phenyl-A }}\right), 6.12(\mathrm{t}$, $\left.J=6.0 \mathrm{~Hz}, 1 \mathrm{H}, 2^{\prime}-\mathrm{CH}\right), 6.00\left(\mathrm{dd}, J=5.7,3.0 \mathrm{~Hz}, 1 \mathrm{H}, 3^{\prime}-\mathrm{CH}\right), 4.89\left(\mathrm{~m}, 1 \mathrm{H}, 4^{\prime}-\mathrm{CH}\right), 4.44(\mathrm{~m}, 2 \mathrm{H}$, 5'- $\mathrm{CH}_{2}$ ), $3.74\left(\mathrm{~s}, 3 \mathrm{H}, \mathrm{CH}_{3 \mathrm{~B}}\right.$ ), $3.56\left(\mathrm{~s}, 3 \mathrm{H}, \mathrm{CH}_{3} \mathrm{~A}\right), 3.17$ (q, J=7.3 Hz, 18H, CH $\left.\mathrm{CHEt}_{2}\right), 1.26$ (t, $\left.J=7.1 \mathrm{~Hz}, 27 \mathrm{H}, \mathrm{CH}_{3 \mathrm{NEt3}}\right) .{ }^{13} \mathrm{C}$ NMR $\left(\mathrm{D}_{2} \mathrm{O}, 151 \mathrm{MHz}\right): \delta(\mathrm{ppm})=166.5\left(1 \mathrm{C}, \mathrm{C}=\mathrm{O}_{\mathrm{B}}\right), 165.9(1 \mathrm{C}$, $C=\mathrm{O}_{\mathrm{A}}$ ), 163.7 (1C, C-4 phenyl-B), 163.6 (1C, C-4 phenyl-A), 154.5 (1C, C-6 purine $_{\text {) }}, 151.6$ (1C, C-2 purine $_{\text {) }}$,

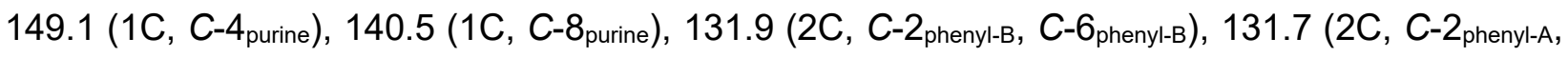
C- $\left.6_{\text {phenyl-A }}\right), 120.6$ (1C, $\left.C-1_{\text {phenyl-B }}\right), 120.0$ (1C, C-1 phenyl-A), 113.9 (2C, C-3 $\left.3_{\text {phenyl-B }}, C-5_{\text {phenyl-B }}\right), 113.7$ (2C, C-3 $3_{\text {phenyl-A, }} C-5_{\text {phenyl-A) }}, 85.2\left(1 \mathrm{C}, C^{-1}{ }^{\prime}\right), 82.2\left(\mathrm{~d}, J=9.1 \mathrm{~Hz}, 1 \mathrm{C}, C-4^{\prime}\right), 74.3\left(1 \mathrm{C}, C-3^{\prime}\right), 73.1$ (1C, C-2'), 65.6 (1C, C-5'), $55.6\left(1 \mathrm{C}, \mathrm{CH}_{3 \mathrm{~B}}\right), 55.4\left(1 \mathrm{C}, \mathrm{CH}_{3 \mathrm{~A}}\right), 46.7$ (9C, $\left.\mathrm{CH}_{2 \mathrm{NEt}}\right), 8.3$ (9C, $\mathrm{CH}_{3 \mathrm{NEt}}$ ). $C-5_{\text {purine }}$ could not be seen. ${ }^{31} \mathrm{P}$ NMR $\left(160 \mathrm{MHz}, \mathrm{D}_{2} \mathrm{O}\right): \delta(\mathrm{ppm})=-10.8$ and $-11.6(2 \mathrm{P}, \alpha-\mathrm{P}, \beta-\mathrm{P})$, $23.1(1 \mathrm{P}, \mathrm{y}-\mathrm{P})$.

2',3'-O-Bis(naphtho-1-yl)-adenosine 5'-(tetrahydrogene triphosphate) (26)

The product was obtained as colorless solid after lyophilization (2.5 eq. Et ${ }_{3} \mathrm{~N}$-salt [1068.50 g/mol], $70 \mathrm{mg}, 65.5 \mu \mathrm{mol}, 6.6 \%$ ). $R_{t}$ (Sephadex-A): $25.6 \mathrm{~min}$. $R_{t}$ (RP-HPLC-D): $30.9 \mathrm{~min}$. Purity (HPLCB): $96 \%\left(R_{t}=14.6 \mathrm{~min}\right)$. LC-MS: $\mathrm{m} / \mathrm{z}=$ calcd. for $\mathrm{C}_{32} \mathrm{H}_{27} \mathrm{~N}_{5} \mathrm{O}_{15} \mathrm{P}_{3}$ 814.1, found $814.0[\mathrm{M}-\mathrm{H}]^{-}$ $\left(R_{t}=5.98 \mathrm{~min}\right.$ ). Exact mass $(\mathrm{ESI}): \mathrm{m} / \mathrm{z}=$ calcd. for $\mathrm{C}_{32} \mathrm{H}_{27} \mathrm{~N}_{5} \mathrm{O}_{15} \mathrm{P}_{3} 814.0722$, found 814.0752 $[\mathrm{M}-\mathrm{H}]^{-} .{ }^{1} \mathrm{H}$ NMR $\left(\mathrm{D}_{2} \mathrm{O}, 600 \mathrm{MHz}\right): \delta(\mathrm{ppm})=8.65\left(\mathrm{~s}, 1 \mathrm{H}, 8-\mathrm{CH}_{\text {purine }}\right), 8.25(\mathrm{~d}, \mathrm{~J}=8.2 \mathrm{~Hz})$ and 8.15 (d, $\left.J=8.3 \mathrm{~Hz}, 3 \mathrm{H}, 8-\mathrm{CH}_{\text {naphthoyl-A, }} 8-\mathrm{CH}_{\text {naphthoyl-B, }}, 2-\mathrm{CH}_{\text {purine }}\right), 7.94\left(\mathrm{~m}, 1 \mathrm{H}, 2-\mathrm{CH}_{\text {naphthoyl-B }}\right), 7.68(\mathrm{~m}$, $\left.1 \mathrm{H}, 2-\mathrm{CH}_{\text {naphthoyl-A }}\right), 7.20\left(\mathrm{~m}, 1 \mathrm{H}, 4-\mathrm{CH}_{\text {naphthoyl-B }}\right), 7.01(\mathrm{~m})$ and $6.65\left(\mathrm{~m}, 2 \mathrm{H}, 5-\mathrm{CH}_{\text {naphthoyl-A, }}\right.$ 5-CH $\left.\mathrm{CH}_{\text {naphthoyl-B }}\right), 6.83\left(\mathrm{~m}, 1 \mathrm{H}, 3-\mathrm{CH}_{\text {naphthoyl-B }}\right), 6.79(\mathrm{~m})$ and $6.69\left(\mathrm{~m}, 2 \mathrm{H}, 7-\mathrm{CH}_{\text {naphthoyl-A, }}, 7-\mathrm{CH}_{\text {naphthoyl- }}\right.$ B), $6.73(\mathrm{~m})$ and $6.53\left(\mathrm{~m}, 3 \mathrm{H}, 4-\mathrm{CH}_{\text {naphthoyl-B, }}, 6-\mathrm{CH}_{\text {naphthoyl-A, }} 6-\mathrm{CH}_{\text {naphthoyl-B }}\right), 6.41\left(\mathrm{~m}, 1 \mathrm{H}, 1^{\prime}-\mathrm{CH}\right), 6.37$

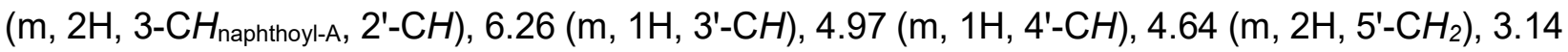
(q, $\left.J=7.4 \mathrm{~Hz}, 15 \mathrm{H}, \mathrm{CH}_{2 \mathrm{NEt}}\right), 1.26\left(\mathrm{t}, J=7.5 \mathrm{~Hz}, 22.5 \mathrm{H}, \mathrm{CH}_{3 \mathrm{NEt}}\right) .{ }^{13} \mathrm{C} \mathrm{NMR}\left(\mathrm{D}_{2} \mathrm{O}, 151 \mathrm{MHz}\right): \delta$ 
$(p p m)=166.4\left(1 \mathrm{C}, C=\mathrm{O}_{\mathrm{B}}\right), 165.9\left(1 \mathrm{C}, \mathrm{C}=\mathrm{O}_{\mathrm{A}}\right), 151.5$ (1C,C-6 purine $\left._{1}\right), 148.2\left(1 \mathrm{C}, \mathrm{C}-4_{\text {purine }}\right), 147.7$ (1C, C-2 purine $_{\text {) }}, 141.5$ (1C, C-8 $\left.8_{\text {purine }}\right), 133.8$ (1C,C-4 naphthoyl-B), 133.5 (1C, C-4 naphthoyl-A), 133.0 and

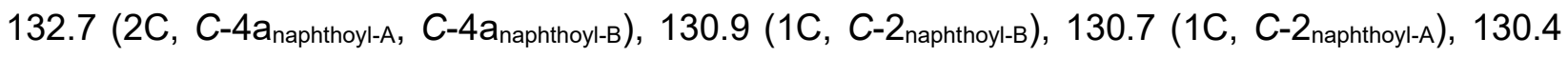

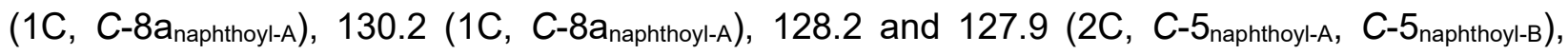
127.5 (2C, C-7 naphthoyl-A, $C-7$ naphthoyl-B), 125.7 (2C, C-6 naphthoyl-A, $C$-6 $\left.6_{\text {naphthoyl-B }}\right), 124.6$ (2C, C-8 naphthoyl-A, C-8 naphthoyl-B) $_{\text {B }} 124.6$ and 124.3 (2C, C-1 naphthoyl-A, $C$-1 naphthoyl-B), 124.3 (1C, C-3 naphthoyl-B), 123.8 (1C, C-3naphthoyl-A), 118.2 (1C, $C-5_{\text {purine) }}$ ), 86.3 (1C, $\left.C-1^{\prime}\right), 82.2$ (1C, C-4'), 74.9 (1C, C-3'), 72.0 (1C, C-2'), 65.5 (1C, C-5'), $46.6\left(7.5 \mathrm{C}, \mathrm{CH}_{2 \mathrm{NEt}}\right), 8.3\left(7.5 \mathrm{C}, \mathrm{CH}_{3 \mathrm{NEt3}}\right) .{ }^{31} \mathrm{P} \mathrm{NMR}\left(160 \mathrm{MHz}, \mathrm{D}_{2} \mathrm{O} / \mathrm{D}_{3} \mathrm{PO}_{4}\right)$ : $\delta(p p m)=-10.8,-11.6(2 \mathrm{P}, \alpha-\mathrm{P}, \beta-\mathrm{P}),-23.0(1 \mathrm{P}, \mathrm{\gamma}-\mathrm{P})$.

\section{Data analysis}

NMR spectra were processed with MestReNova 12.0 (MestreLab Research).

\section{Assays}

\section{Cells}

Stable human embryonic kidney 293 (HEK-293) cells stably expressing human P2X7 receptor (B'SYS GmbH) were maintained in 50/50 mix of Dulbecco's Modified Eagle Medium with F12 medium (DMEM/F12, Thermo Fisher Scientific) supplemented with $9 \%$ fetal calf serum (FCS), $1 \%$ Penicillin/Streptomycin (10.000 units penicillin and 10mg streptomycin per $\mathrm{mL}$ in $0.9 \% \mathrm{NaCl}$,

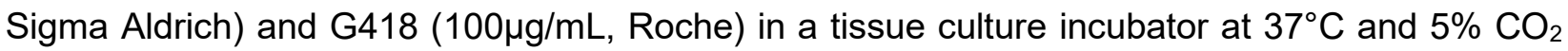
under humidified conditions. Cells were cultured in cell culture $75 \mathrm{~cm}^{2}$ flasks and split every 2-4 days $(1: 3 ; 1: 6 ; 1: 10)$ once confluent.

The HEK293 cell line stably expressing human P2X4 receptor and CHO cells stably expressing human P2X2/3 receptor (B'SYS GmbH) were cultured under same conditions using Puromycin $(1.0 \mu \mathrm{g} / \mathrm{ml}$, Thermo Fisher Scientific) as a selection antibiotic.

Chinese hamster ovary $(\mathrm{CHO})$ cell lines stably expressing human $\mathrm{P} 2 \mathrm{X} 1$ receptor, $\mathrm{P} 2 \mathrm{X} 2$ receptor or P2X3 receptor (B'SYS GmbH) were cultured under same conditions using Hygromycin (100 $\mu \mathrm{g} / \mathrm{ml}$, Invivogen) as a selection antibiotic. 
THP-1 cells $\left(\right.$ ATCC $^{\circledR}$, Manassas, VA) were maintained in growth media (RPMI-1640; HyClone ${ }^{\circledR}$ ) supplemented with 10\% FCS (Pan-Biotech).

\section{YO-PRO-1 Uptake Assay}

The assay was performed as previously reported. ${ }^{2}$ Briefly, HEK-293 cells expressing P2X7 receptor were seeded into black-walled Nunc 96 well optical bottom plates (Thermo Fisher Scientific) at 2.0-4.0 $\times 10^{4}$ cells/well and incubated for 24-48 hours. All compounds in this procedure were diluted in assay buffer. Cells were washed with $100 \mu \mathrm{L}$ wash buffer $(280 \mathrm{mM}$ Sucrose; $5.6 \mathrm{mM} \mathrm{KCl} ; 0.5 \mathrm{mM} \mathrm{CaCl}$; $10 \mathrm{mM}$ D-Glucose; $10 \mathrm{mM}$ HEPES; $5 \mathrm{mM} \mathrm{N}$-methyl-Dglucamine ( $\mathrm{pH} 7.42)$ ). After removing the wash buffer, $50 \mu \mathrm{L}$ assay buffer (280 mM Sucrose; 6.35 mM KCl; 10 mM D-Glucose; 10 mM HEPES; 5 mM N-methyl-D-glucamine (pH 7.4)) and $50 \mu \mathrm{L}$ of antagonist dilution at five different concentrations $\left(10^{-5}\right.$ to $\left.10^{-9} \mathrm{M}\right)$ were added to the cells for preincubation for 30 minutes at $37^{\circ} \mathrm{C}$. Next, the cells were incubated with additional $50 \mu \mathrm{L}$ of a final concentration of $2 \mu \mathrm{mol} \cdot \mathrm{L}^{-1} \mathrm{YO}-\mathrm{PRO}-1$ lodide (Sigma Aldrich) and $50 \mu \mathrm{L}$ of BzBzATP (determined $\mathrm{EC}_{50}$-value under the assay conditions) at $37^{\circ} \mathrm{C}$ for 2 hours. Finally the uptake of the YO-PRO-1 dye was recorded in a 9-point-well scan by following the fluorescence change using a FlexStation $\circledast 3$ Multi-Mode Microplate Reader (Molecular Devices, San Jose, CA, USA, Software SoftMax7 Pro, endpoint protocol, well scan with reading pattern "fill scan", ex: 485 nm, em: 535 $\mathrm{nm})$. To obtain the concentration-dependent uptake inhibition by antagonists, the YO-PRO-1 uptake was plotted against concentrations of the compounds reaching from $10^{-5}$ to $10^{-9} \mathrm{M}$. For measurement of compounds with agonistic activity the cells were preincubated for 30 minutes at $37^{\circ} \mathrm{C}$ with $50 \mu \mathrm{L}$ of assay buffer and additional $50 \mu \mathrm{L}$ assay buffer with $2 \%$ DMSO. Finally, the cells were also coincubated with further $50 \mu \mathrm{L}$ of a final concentration of $2 \mu \mathrm{mol} \cdot \mathrm{L}^{-1} \mathrm{YO}-\mathrm{PRO}-1$ lodide and $50 \mu \mathrm{L}$ of different concentrations of agonists $\left(10^{-3}\right.$ to $\left.10^{-8} \mathrm{M}\right)$ at $37^{\circ} \mathrm{C}$ for 2 hours. The concentration-dependent increase of dye uptake was equally recorded and plotted against the six different concentrations of the agonists $\left(10^{-3}\right.$ to $\left.10^{-8} \mathrm{M}\right)$. 


\section{$\mathrm{Ca}^{2+}$ flux Assay}

Fluo-4 NW and Fluo-4 Direct kit were prepared according to the manufacturer's directions. HEK293 and CHO cells were seeded into black-walled Nunc 96 well plates (Thermo Fisher Scientific) at 2.0-4.0 × $10^{4}$ cells/well and incubated for $24-48$ hours at $37{ }^{\circ} \mathrm{C}$ until confluent. All test compounds in this procedure were diluted in buffer solution $(280 \mathrm{mM}$ Sucrose; $6.35 \mathrm{mM} \mathrm{KCl} ; 10$ mM D-Glucose; 10 mM HEPES; 5 mM N-methyl-D-glucamine (pH 7.4)). The growth medium was removed, and the cells were washed using $100 \mu \mathrm{L}$ HBSS including $20 \mathrm{mM}$ HEPES. Loading with $100 \mu \mathrm{L}$ of the fluorescent $\mathrm{Ca}^{2+}$ indicator Fluo-4 AM was performed at $37^{\circ} \mathrm{C}$ for one hour. The cells were further incubated at room temperature for additional 30 minutes after adding $50 \mu \mathrm{L}$ of five different concentrations of antagonists $\left(10^{-5}\right.$ to $10^{-9} \mathrm{M}$ ). Finally, $50 \mu \mathrm{L}$ of ATP (concentration of previously determined $\mathrm{EC}_{50}$-values) was added by using the FlexStation $\circledast 3$ Multi-Mode Microplate Reader (Molecular Devices, San Jose, CA, USA, Software SoftMax7 Pro). The changes of intracellular $\mathrm{Ca}^{2+}$ concentrations were monitored over 200 seconds by measuring the fluorescence signal at $\lambda_{\mathrm{ex}}=494 \mathrm{~nm}$ and $\lambda_{\mathrm{em}}=516 \mathrm{~nm}$. The concentration-dependent decrease of $\mathrm{Ca}^{2+}{ }^{2}$ flux in presence of antagonists was plotted against the five concentrations $\left(10^{-5}\right.$ to $\left.10^{-9} \mathrm{M}\right)$. The activity of agonists was evaluated in the same manner, different concentrations of agonists reaching from $10^{-3}$ to $10^{-8} \mathrm{M}$ were added by the FlexStation $® 3$. The concentration-dependent increase of $\mathrm{Ca}^{2+}-$ flux in presence of agonists was plotted against the six different concentrations $\left(10^{-3}\right.$ to $\left.10^{-8} \mathrm{M}\right)$.

\section{THP-1 Cell IL-1 $\beta$ Release Assay}

Seed cells to a density of 1.5 to $2.0 \times 10^{4}$ cells/well in a 96-well plate (Corning Costar 9018, Sigma Aldrich). Cells were differentiated with $10 \mathrm{ng} / \mathrm{mL}$ of interferon $\gamma$ (IFN- $\gamma$ ) (Sigma Aldrich) over 72 hours at $37^{\circ} \mathrm{C}$ and $5 \% \mathrm{CO}_{2}$. Priming of cells by adding lipopolysaccharides (LPS) (Sigma Aldrich) to a final concentration of $100 \mathrm{ng} / \mathrm{mL}$. The plates were covered with parafilm ${ }^{\circledR} \mathrm{M}$ (Sigma Aldrich) and incubated at $37^{\circ} \mathrm{C}$ and $5 \% \mathrm{CO}_{2}$ for further 4 hours. Test compounds diluted in RPMI 1640 medium to final concentrations of $1.0 \times 10^{-3} \mathrm{~mol} / \mathrm{L}$ to $1.0 \times 10^{-8} \mathrm{~mol} / \mathrm{L}$ were added to the corresponding wells and coincubated for an additional hour. Centrifuge the 96 well plates for 10 
minutes at $750 \vec{g}$. The supernatant from the wells was transferred to a second 96 -well plate (Corning Costar 9018, Sigma Aldrich). The IL-1 $\beta$ concentration in the supernatants was measured as absorption at $450 \mathrm{~nm}$ using a human IL-1 beta uncoated ELISA kit (Invitrogen) and a FlexStation ${ }^{\circledR} 3$ Multi-Mode Microplate Reader (Molecular Devices, San Jose, CA, USA, Software SoftMax7 Pro).

\section{Data analysis}

The inhibition curves from three independent measurements, each done in duplicate were fitted to the Hill equation using GraphPad Prism software version 9.1.0 (GraphPad Software Inc. San Diego, CA, USA). The results represent the mean $\pm \operatorname{SEM}(n \geq 3)$.

\section{In silico studies}

Multiple sequence alignment: The protein sequences of $h P 2 X 1$ (UniProtKB: P51575), $h P 2 X 2$ (UniProtKB: Q9UBL9), hP2X3 (UniProtKB: P56373), hP2X4 (UniProtKB: Q99571) and hP2X7 (UniProtKB: Q99572) were obtained from the UniProt Knowledgebase. ${ }^{37}$ Multiple sequence alignment was carried out using the multiple sequence alignment program Clustal Omega (https://www.ebi.ac.uk/Tools/msa/clustalo/) with default settings.

Homology models: Homology model of the missing human receptors were made using MOE (2019.0102). As a template for the homology model of hP2X4, the ATP bound zfP2X4 (4DW1) ${ }^{35}$ was used, while the $\mathrm{rP} 2 \mathrm{X} 7(6 \mathrm{U} 9 \mathrm{~W})^{36}$ was used for the hP2X7. Since there were no crystal structures for any $\mathrm{P} 2 \mathrm{X} 2$ receptors available, the $\mathrm{hP} 2 \mathrm{X} 3(5 \mathrm{SVK})^{13}$ crystal structure was used as template. To analyse the heterotrimer P2X2/3 receptor, two models were designed to represent both possibilities. Sequences of the human P2X receptors were aligned with the template sequence and ten independent homology models were created for each model using default 
settings in MOE. All homology models are supposed to represent the ATP-bound/open state of the receptors.

Energy minimization studies: Energy minimization studies were done using MOE (2019.0102). The conformation of ATP bound in the template structure were used to model compounds 24-26, by modifying ATP using MOE Builder. During the energy minimization, the translational movements of the compound was limited by using tether forces, while amino acids in close proximity to the compound (Highlighted in Figure 4) were defined as fully flexible. Amino acids of the neighboring residues were defined as fixed, while the rest of the protein was defined as inert. Energy minimization was carried out using the Amber10:EHT forcefield with default settings, while the structural rearrangements were observed.

\section{Supporting information}

${ }^{1} \mathrm{H},{ }^{13} \mathrm{C}$, and ${ }^{31} \mathrm{P}$ NMR spectra of all compounds, plots of pharmacological data and molecular modeling figures are included in Supporting Information. This material is available free of charge in the Internet at http://pubs.acs.org.

\section{Acknowledgment}

AJ thanks the German Research Foundation (DFG) for the financial support (JU 2966/2-1). AJ, OK thank the German Research Foundation (DFG) for the financial support (GRK2515/1-1).

\section{Abbreviations}

AM, acetoxymethylester; ATP, adenosine 5'-triphosphate; ATP $\gamma$ S, adenosine-5'-O-(3thiotriphosphate); $\alpha, \beta$-meATP, alpha, beta-methylene-ATP; $\beta, \gamma$-meATP, beta, gamma-methylene- 
ATP; BzBzATP, 2' (3')-O-(4-benzoyl)benzoyl-ATP; CHO, Chinese hamster ovary; cV, column volume; dec., decomposition; DMEM, Dulbecco's modified Eagle's medium; DMF, N,Ndimethylformamide; DMSO, dimethylsulfoxide; EGTA ethylene glycol-bis( $\beta$-aminoethyl ether)$\mathrm{N}, \mathrm{N}, \mathrm{N}^{\prime}, \mathrm{N}$ '-tetraacetic acid; ESI, electrospray ionization; HBSS, Hanks' balanced salt solution; HEK, human embryonic kidney cells; HEPES, 4-(2-hydroxyethyl)-1-piperazineethanesulfonic acid; HPLC, high performance liquid chromatography; IFNy, interferon $\gamma ;$ IL-1 $\beta$, interleukin-1 $\beta$; LC-MS, liquid chromatography-mass spectrometry; LPS, lipopolysaccharide; 2-meSATP, 2methylthio-ATP; MOE, Molecular Operating Environment; PBS, phosphate-buffered saline; pdb, protein data bank; SAR, structure-activity relationship; SEM, standard error of the mean; THF, tetrahydrofuran; TM, transmembrane helix.

${ }^{*}$ Corresponding author: Anna Junker

anna.junker@uni-muenster.de, European Institute for Molecular Imaging (EIMI) der Westfälischen Wilhelms-Universität Münster Waldeyerstraße 15, D-48149 Münster, Germany.

\section{Authors}

Andreas Isaak, European Institute for Molecular Imaging (EIMI), Waldeyerstr. 15, Münster, Germany.

Clemens Dobelmann, European Institute for Molecular Imaging (EIMI), Waldeyerstr. 15, Münster, Germany.

Friederike Füsser, Institut für Pharmazeutische und Medizinische Chemie der Universität Münster, Corrensstr. 48, Münster, Germany.

Katharina Erlitz, European Institute for Molecular Imaging (EIMI), Waldeyerstr. 15, Münster, Germany.

Oliver Koch, Institut für Pharmazeutische und Medizinische Chemie der Universität Münster, Corrensstr. 48, Münster, Germany. 


\section{Author Contributions}

The manuscript was written through the contributions of all authors. All authors have given approval to the final version of the manuscript.

\section{Notes}

The authors declare no competing financial interest.

\section{References}

(1) North, R. A. Molecular physiology of P2X receptors. Physiol. Rev. 2002, 82, 1013-1067.

(2) Valera, S.; Hussy, N.; Evans, R. J.; Adami, N.; North, R. A.; Surprenant, A.; Buell, G. A new class of ligand-gated ion channel defined by P2x receptor for extracellular ATP. Nature 1994, 371, 516-519.

(3) Brake, A. J.; Wagenbach, M. J.; Julius, D. New structural motif for ligand-gated ion channels defined by an ionotropic ATP receptor. Nature 1994, 371, 519-523.

(4) Jiang, R.; Taly, A.; Lemoine, D.; Martz, A.; Cunrath, O.; Grutter, T. Tightening of the ATPbinding sites induces the opening of $P 2 X$ receptor channels. EMBO J. 2012, 31, 2134-2143.

(5) Samways, D. S. K.; Khakh, B. S.; Dutertre, S.; Egan, T. M. Preferential use of unobstructed lateral portals as the access route to the pore of human ATP-gated ion channels (P2X receptors). PNAS 2011, 108, 13800-13805.

(6) Virginio, C.; MacKenzie, A.; Rassendren, F. A.; North, R. A.; Surprenant, A. Pore dilation of neuronal P2X receptor channels. Nat. Neurosci. 1999, 2, 315-321.

(7) Khakh, B. S.; Henderson, G. ATP receptor-mediated enhancement of fast excitatory neurotransmitter release in the brain. Mol. Pharmacol. 1998, 54, 372-378.

(8) Gu, J. G.; MacDermott, A. B. Activation of ATP P2X receptors elicits glutamate release from sensory neuron synapses. Nature 1997, 389, 749-753.

(9) Cockcroft, S.; Gomperts, B. D. ATP induces nucleotide permeability in rat mast cells. Nature 1979, 279, 541-542.

(10) Bours, M. J. L.; Dagnelie, P. C.; Giuliani, A. L.; Wesselius, A.; Di Virgilio, F. P2 receptors and extracellular ATP: a novel homeostatic pathway in inflammation. Front. Biosci. (Schol. Ed) 2011, 3, 1443-1456.

(11) Burnstock, G. Physiology and pathophysiology of purinergic neurotransmission. Physiol. Rev. 2007, 87, 659-797.

(12) Tsuda, M.; Shigemoto-Mogami, Y.; Koizumi, S.; Mizokoshi, A.; Kohsaka, S.; Salter, M. W.; Inoue, K. P2X4 receptors induced in spinal microglia gate tactile allodynia after nerve injury. Nature 2003, 424, 778-783.

(13) Mansoor, S. E.; Lü, W.; Oosterheert, W.; Shekhar, M.; Tajkhorshid, E.; Gouaux, E. X-ray structures define human $\mathrm{P} 2 \mathrm{X}(3)$ receptor gating cycle and antagonist action. Nature 2016, 538, 66-71.

(14) Kawate, T.; Michel, J. C.; Birdsong, W. T.; Gouaux, E. Crystal structure of the ATP-gated P2X(4) ion channel in the closed state. Nature 2009, 460, 592-598.

(15) Karasawa, A.; Kawate, T. Structural basis for subtype-specific inhibition of the P2X7 receptor. elife 2016, 5. 
(16) Kasuya, G.; Yamaura, T.; Ma, X.-B.; Nakamura, R.; Takemoto, M.; Nagumo, H.; Tanaka, E.; Dohmae, N.; Nakane, T.; Yu, Y.; et al. Structural insights into the competitive inhibition of the ATPgated P2X receptor channel. Nat. Comm. 2017, 8, 876.

(17) Kasuya, G.; Fujiwara, Y.; Tsukamoto, H.; Morinaga, S.; Ryu, S.; Touhara, K.; Ishitani, R.; Furutani, Y.; Hattori, M.; Nureki, O. Structural insights into the nucleotide base specificity of P2X receptors. Sci. Rep. 2017, 7, 45208.

(18) Ennion, S.; Hagan, S.; Evans, R. J. The role of positively charged amino acids in ATP recognition by human P2X(1) receptors. J. Biol. Chem. 2000, 275, 29361-29367.

(19) Bianchi, B. R.; Lynch, K. J.; Touma, E.; Niforatos, W.; Burgard, E. C.; Alexander, K. M.; Park, H. S.; Yu, H.; Metzger, R.; Kowaluk, E.; et al. Pharmacological characterization of recombinant human and rat P2X receptor subtypes. Eur. J. Pharmacol. 1999, 376, 127-138.

(20) Ding, S.; Sachs, F. Single channel properties of P2X2 purinoceptors. J. Gen. Physiol. 1999, 113, 695-720.

(21) Lynch, K. J.; Touma, E.; Niforatos, W.; Kage, K. L.; Burgard, E. C.; van Biesen, T.; Kowaluk, E. A.; Jarvis, M. F. Molecular and functional characterization of human P2X(2) receptors. Mol. pPharmacol.1999, 56, 1171-1181.

(22) Jacobson, K. A.; Jarvis, M. F.; Williams, M. Purine and pyrimidine (P2) receptors as drug targets. J.Med. Chem. 2002, 45, 4057-4093.

(23) Chen, C. C.; Akopian, A. N.; Sivilotti, L.; Colquhoun, D.; Burnstock, G.; Wood, J. N. A P2X purinoceptor expressed by a subset of sensory neurons. Nature 1995, 377, 428-431.

(24) Hausmann, R.; Bodnar, M.; Woltersdorf, R.; Wang, H.; Fuchs, M.; Messemer, N.; Qin, Y.; Günther, J.; Riedel, T.; Grohmann, M.; et al. ATP binding site mutagenesis reveals different subunit stoichiometry of functional $\mathrm{P} 2 \mathrm{X} 2 / 3$ and $\mathrm{P} 2 \mathrm{X} 2 / 6$ receptors. J. Biol. Chem. 2012, 287, 13930-13943.

(25) Welford, L. A.; Cusack, N. J.; Hourani, S. M.O. The structure-activity relationships of ectonucleotidases and of excitatory P2-purinoceptors: evidence that dephosphorylation of ATP analogues reduces pharmacological potency. Eur. J. Pharmacol. 1987, 141, 123-130.

(26) Lewis, C.; Neidhart, S.; Holy, C.; North, R. A.; Buell, G.; Surprenant, A. Coexpression of $\mathrm{P} 2 \mathrm{X} 2$ and $\mathrm{P} 2 \mathrm{X} 3$ receptor subunits can account for ATP-gated currents in sensory neurons. Nature 1995, 377, 432-435.

(27) Illes, P.; Müller, C. E.; Jacobson, K. A.; Grutter, T.; Nicke, A.; Fountain, S. J.; Kennedy, C.; Schmalzing, G.; Jarvis, M. F.; Stojilkovic, S. S.; et al. Update of P2X receptor properties and their pharmacology: IUPHAR Review 30. Br. J. Pharmacol.2021, 178, 489-514.

(28) Coddou, C.; Yan, Z.; Obsil, T.; Huidobro-Toro, J. P.; Stojilkovic, S. S. Activation and regulation of purinergic P2X receptor channels. Pharmacol. Rev. 2011, 63, 641-683.

(29) Virginio, C.; Robertson, G.; Surprenant, A.; North, R. A. Trinitrophenyl-substituted nucleotides are potent antagonists selective for $\mathrm{P} 2 \mathrm{X} 1, \mathrm{P} 2 \mathrm{X} 3$, and heteromeric $\mathrm{P} 2 \mathrm{X} 2 / 3$ receptors. Mol. Pharmacol.1998, 53, 969-973.

(30) Carrasquero, L. M. G.; Delicado, E. G.; Bustillo, D.; Gutiérrez-Martín, Y.; Artalejo, A. R.; Miras-Portugal, M. T. P2X7 and P2Y13 purinergic receptors mediate intracellular calcium responses to BzATP in rat cerebellar astrocytes. J. Neurochem.2009, 110, 879-889.

(31) Duan, S.; Anderson, C. M.; Keung, E. C.; Chen, Y.; Chen, Y.; Swanson, R. A. P2X 7 Receptor-Mediated Release of Excitatory Amino Acids from Astrocytes. J. Neurosci. 2003, 23, 1320-1328.

(32) Nuttle, L. C.; Dubyak, G. R. Differential activation of cation channels and non-selective pores by macrophage P2z purinergic receptors expressed in Xenopus oocytes. J. Biol. Chem. 1994, 269, 13988-13996. 
(33) John, G. R.; Simpson, J. E.; Woodroofe, M. N.; Lee, S. C.; Brosnan, C. F. Extracellular Nucleotides Differentially Regulate Interleukin- $1 \beta$ Signaling in Primary Human Astrocytes: Implications for Inflammatory Gene Expression. J. Neurosci. 2001, 21, 4134-4142.

(34) Jacobson, K. A.; Müller, C. E. Medicinal chemistry of adenosine, P2Y and P2X receptors. Neuropharmacology 2016, 104, 31-49.

(35) Hattori, M.; Gouaux, E. Molecular mechanism of ATP binding and ion channel activation in P2X receptors. Nature 2012, 485, 207-212.

(36) McCarthy, A. E.; Yoshioka, C.; Mansoor, S. E. Full-Length P2X7 Structures Reveal How Palmitoylation Prevents Channel Desensitization. Cell 2019, 179, 659-670.e13.

(37) UniProt: the universal protein knowledgebase in 2021. Nucleic Acids Res. 2021, 49, D480D489. 